\title{
Energy Efficiency Campaign for Residential Housing at the Fort Lewis Army Installation
}

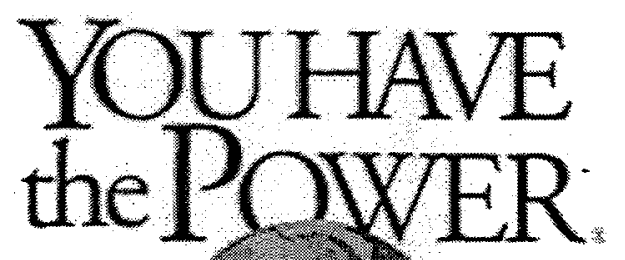

Prepared for the

U.S. Department of Energy

Office of Energy Efficiency and Renewable Energy

Federal Energy Management Program

Prepared by

Pacific Northwest National Laboratory

Andrea H. McMakin

Regina E. Lundgren

Elizabeth L. Malone 


\section{DISCLAIMER}

This report was prepared as an account of work sponsored by an agency of the United States Government. Neither the United States Government nor any agency thereof, nor any of their employees, make any warranty, express or implied, or assumes any legal liability or responsibility for the accuracy, completeness, or usefulness of any information, apparatus, product, or process disclosed, or represents that its use would not infringe privately owned rights. Reference herein to any specific commercial product, process, or service by trade name, trademark, manufacturer, or otherwise does not necessarily constitute or imply its endorsement, recommendation, or favoring by the United States Government or any agency thereof. The views and opinions of authors expressed herein do not necessarily state or reflect those of the United States Government or any agency thereof. 


\section{DISCLAIMER}

Portions of this document may be illegible in electronic image products. Images are produced from the best available original document. 


\section{Summary}

In FY 1999. Pacific Northwest National Laboratory conducted an energy efficiency campaign for residential housing at the Fort Lewis Army Installation near Tacoma, Washington. Preliminary weather-corrected calculations show energy savings of $10 \%$ from Fy98 for energy use in family housing. This exceeded the project's goal of $3 \%$.

The work was funded by the U.S. DOE's Federal Energy Management Program (FEMP), Office of Energy Efficiency and Renewable Energy. The project adapted FEMP's national "You Have the Power Campaign" at the local level, tailoring it to the military culture.

The applied research project was designed to demonstrate the feasibility of tailored, research-based strategies to promote energy conservation in military family housing. In contrast to many energy efficiency efforts, the campaign focused entirely on actions residents could take in their own homes, as opposed to technology or housing upgrades.

Behavioral change was targeted because residents do not pay their own utility bills; thus other motivators must drive personal energy conservation. This campaign augments ongoing energy savings from housing upgrades carried out by Fort Lewis.

The campaign ran from September 1998 through August 1999. The campaign strategy was developed based on findings from previous research and on input from residents and officials at Fort Lewis.

Energy use, corrected to account for weather differences, was compared with the previous year's use. Survey responses from $37 \%$ of Fort Lewis residents of occupied housing showed that the campaign was moderately effective in promoting behavior change. Of those who were aware of the campaign, almost all said they were now doing one or more energy-efficient things that they had not done before.

Most people were motivated by the desire to "do the right thing" and to set a good example for their children. They were less motivated by other factors, such as the potential of receiving a financial incentive for their community or competition with other communities on post. Residents identified the most significant barrier to energy efficiency as poorly constructed houses that waste heat.

When asked what it would take to motivate continued energy efficiency, respondents overwhelmingly identified increased information and awareness, disincentives, and incentives.

This pilot study revealed some important factors that were tested for the first time in military residential housing. Based on the results, the following strategies are recommended:

- Tailor actions and approaches to the military installation's people, situation, and culture.

- To raise awareness with this particularly mobile population, use direct contact with residents as much as possible, and repeat the messages and targeted behaviors often.

- Emphasize the energy-efficiency benefits of personal comfort, improved health, and convenience.

- Tap into peoples' socially responsible values-pride in their own energy-efficient lifestyles, their desire to do the right thing, and their inclination to set a good example for their children. 
- Address information gaps or misinterpretations in peoples' "mental models" that may affect the actions they take.

- Make sure factors that could affect the campaign results-including the instaliation's policy constraints, staff and resource availability, and ongoing housing upgrades that affect energy efficiency-are clearly understood and factored into the campaign design and goals.

Additional work should be conducted to test the following approaches in field situations:

- To institutionalize long-term change, it may be most effective to combine a variety of motivators, including appeal to environmental and parental responsibility, direct outreach to kids, written commitments, incentives, and disincentives. Consider the use of written commitments and the newcomer's orientation.

- Give residents mock bills or some other kind of feedback that shows the amount of energy costs they are using over time, perhaps comparing costs with those of a typical range of houses off post. Remind them in these mock bills what they can do to save energy.

- Consider financial incentives and disincentives for energy use. To the extent allowed by existing metering and Congressional mandates, consider requiring payment by residents over a preset cap. Or, consider giving a monthly utilities allowance to on-post families. If they use less than the allowance, they get to keep the remainder. If they use more, they pay the extra.

- Work directly through children to influence parents and other family members.

A compilation of guidelines and examples, "Handbook for Promoting Behavior-Based Energy Efficiency in Military Housing" (McMakin et al., 1999), was written based on experiences from the Fort Lewis campaign and another DOE-funded campaign under way at a Marine base in Arizona. The August 1999 handbook is available through DOE's Energy Efficiency and renewable Energy Clearinghouse in Virginia. 


\section{Contents}

Summary

Preface iv

Need, Purpose, and Scope 1

Approach 1

Implementation 2

Results 5

Conclusions and Discussion

8

Recommendations

9

References

11

Appendixes
A Examples of Information Materials
$B$ Energy Savings
C Survey Results 


\section{Preface}

The mission of the U.S. Department of Energy's Federal Energy Management Program (FEMP) is to reduce the cost of government by advancing energy efficiency, water conservation, and the use of solar and other renewable technologies. This is accomplished by creating partnerships, leveraging resources, transferring technology, and providing training and technical guidance and assistance to agencies. These activities support requirements stated in the Energy Policy Act of 1992 and goals established in the June 1999 Executive Order 13123.

To bolster energy awareness across the federal government, FEMP launched a communications campaign entitled "You Have the Power" in 1997. This campaign assists federal energy managers by spreading the word about energy-efficient practices and products, as well as facilitating partnerships with energy-related organizations in the private sector. The campaign is intended to instill energy efficiency as a basic value among federal workers and the public.

The Pacific Northwest National Laboratory supports the FEMP mission in all activity areas, including the "You Have the Power" campaign. Specifically, Pacific Northwest staff are working with their FEMP colleagues to develop communication processes to promote energy efficiency in federal facilities. In doing so, the cost of government can be further decreased.

This letter report describes an applied research project that tested specific strategies at a military installation in Washington state. The approach used the "You Have the Power" campaign to develop site-specific activities that encouraged residents to use energy more efficiently in military family housing. 
Need, Purpose, and Scope

The purpose of this outreach project was to demonstrate the feasibility of a specific combination of research-based behavioral strategies in promoting energy conservation in military family housing. The outcomes of the project will help guide development and implementation of FEMP's "You Have the Power" campaign under the Communications and Outreach Program.

The project grew out of an initial literature review conducted in 1997 by Pacific Northwest National Laboratory for FEMP (Walker et al., 1997). The review of social science and communication literature identified several theories, methods, and analytical tools of potential use for FEMP. The reviewers recommended that several of these factors be tested in an applied research project to institutionalize energy efficiency as a public value. Consequently. FEMP's Office of Energy Efficiency and Renewable Energy funded a pilot outreach campaign for the Fort Lewis Army Installation in Washington state. (FEMP also funded a complementary project at the Marine Corps Air Station in Yuma, Arizona, which continues into FY 2000.)

The campaign targeted family housing at Fort Lewis, near Tacoma, Washington for one year from September 1998 through August 1999. The goal of the campaign was to motivate individuals to reduce their own electricity and natural gas use, through actions such as more efficient and decreased use of heating, hot water, and lighting. This is a particular challenge at Fort Lewis and other military installations because on-post family housing residents typically do not pay their own utility bills and thus do not have the financial incentive of lower utility payments.

Rather than relying on technology or systematic physical upgrades (a typical focus in federal energy conservation efforts), the campaign focused on motivating behavior change of the residents themselves. Thus, no-cost and low-cost voluntary actions were emphasized.

The campaign involved Fort Lewis's 11 on-post residential housing communities where 12,777 Army personnel live with their families in 3,625 housing units. Residential housing accounts for $40 \%$ of the installation's total energy costs, representing a substantial opportunity for savings.

Pacific Northwest National Laboratory team members worked closely with Department of Public Works personnel at Fort Lewis to conduct the project. The Department of Public Works is responsible for monitoring energy use and implementing programs to use energy efficiently.

\section{Approach}

Working with staff at Ft. Lewis, project staff at Pacific Northwest developed a campaign strategy based on findings from previous research and on input from residents and officials at Fort Lewis. For example, several previous studies described effective strategies for energy efficiency, including videotaped modeling of desired energy behaviors, information development and diffusion, and use of incentives such as comparison and competition (e.g., Costanzo et al., 1986; Dennis et al., 1990; Harrigan, 1991; Harrigan et al., 1995; Hayes and Cone, 1977; Neuman, 1986; Siero et al, 1996; Stern, 1992; Winnet et al., 1985). Findings from these studies were factored into the campaign design to the extent possible.

Focus groups and interviews were used to identify feasible, appropriate, localized strategies that were adapted to the military culture. Focus groups were held with members of two neighborhood groups on post and with Fort Lewis Boy and Girl Scout leaders. Focus groups were used to obtain information directly from residents about how potential campaign messages and images, behaviors to be 
targeted, their views on energy conservation, and ideas for community involvement, incentives, and information dissemination.

Interviews were held with Fort Lewis officials responsible for housing, energy efficiency, and housing maintenance. Interviews were used to better understand housing energy use and conservation issues, and to ensure that officials were made aware of initial campaign plans, and to solicit ideas for the campaign.

Campaign messages, themes, visuals, and approaches were developed using feedback from the focus groups and interviews. The discussions with post residents and officials were tremendously helpful in eliminating noon-workable approaches and identifying the most effective ones for the Fort Lewis environment. For example, people did not want to have energy auditors come to their homes, but they were happy to involve their children in energy-efficiency educational activities in their neighborhoods. We also discovered that it was unsafe to show residents how to turn down the temperatures on their water heaters because it involved working around high-voltage wires.

Thermal comfort was clearly the overriding concern in energy use by residents; several residents complained about inadequate weatherization and problems with thermostats not working properly, making living areas drafty or stifling hot.

Residents chose the symbol of a lightbulb with a glowing dollar sign inside and the slogan, "Smart Energy Use." They wanted the results to be shown in dollars saved, not energy units or dollars spent. They favored the concept of competition once they understood that the housing areas would not be compared with each other (considered unfair because they varied so much) but with their own housing area from the previous year's energy use.

Interestingly, we received mixed feedback on the financial incentive concept. (The Public Works Department had committed to returning a portion of the money saved by each community at the end of the campaign.) One focus group felt that people should conserve energy because it was the right thing to do, and that an incentive was somewhat of an insult. In contrast, another focus group wanted the money to go to individuals rather than in a lump sum to the entire community. Because of the success of financial incentives under certain conditions in the literature (e.g. Hayes and Cone, 1977), we decided to include the financial incentive as one aspect of the campaign.

In line with the military setting, the campaign was called "Operation Energy." Based on previous research and on Fort Lewis energy conservation goals, a goal of $3 \%$ reduction in energy costs in residential housing was set.

Targeted behaviors focused on the biggest energy-users in Fort Lewis residential housing -- heat, lighting, and washing/drying. (Fort Lewis houses do not have air conditioning.)

Campaign effectiveness was measured by reduced energy use and cost as well as feedback from residents about energy-efficiency actions they had begun taking.

\section{Implementation}

Table 1 shows activities and information materials that were used to raise awareness and prompt action by family housing residents at Fort Lewis. Community mayors helped spread the word to their members. Appendix A shows examples of information materials. 
Table 1. Activities and Materials used in the Operation Energy Campaign

\begin{tabular}{|c|c|c|c|c|}
\hline $\begin{array}{l}\text { Activity or In- } \\
\text { formation Piece }\end{array}$ & Purpose & Target Audience & $\begin{array}{l}\text { Time Frame and } \\
\text { distribution }\end{array}$ & Comments \\
\hline $\begin{array}{l}\text { Videotape, "In } \\
\text { Search of the } \\
\text { Energy Bandit" }\end{array}$ & $\begin{array}{l}\text { Encourage spe- } \\
\text { cific behaviors by } \\
\text { having actual } \\
\text { residents, includ- } \\
\text { ing children, mod- } \\
\text { eling target ac- } \\
\text { tivities in and out- } \\
\text { side their homes. } \\
\text { Show top-level } \\
\text { support by having } \\
\text { Colonel speak on } \\
\text { tape about impor- } \\
\text { tance of energy } \\
\text { conservation and } \\
\text { financial incen- } \\
\text { tive. }\end{array}$ & $\begin{array}{l}\text { All residents, in- } \\
\text { cluding adults and } \\
\text { children }\end{array}$ & $\begin{array}{l}\text { Ran on Fort } \\
\text { Lewis's public } \\
\text { access channel in } \\
\text { October and No- } \\
\text { vember } 1998 \text { and } \\
\text { January and April } \\
\text { 1999, from 7-9 } \\
\text { p.m., Monday } \\
\text { through Friday } \\
\text { and in the after- } \\
\text { noon on weekends. } \\
\text { Also shown at } \\
\text { mayors' meetings } \\
\text { and to monthly } \\
\text { troop training } \\
\text { classes. }\end{array}$ & \\
\hline $\begin{array}{l}\text { Readerboard mes- } \\
\text { sages: "October is } \\
\text { Energy Awareness } \\
\text { Month: turn your } \\
\text { thermostats to } 70 \\
\text { F." "Support Op- } \\
\text { eration Energy- } \\
\text { set your refrig- } \\
\text { erator temp to } \\
37-40 \text { F." "Turn } \\
\text { off all outside } \\
\text { lights during day- } \\
\text { light hours," etc. }\end{array}$ & $\begin{array}{l}\text { Capture attention, } \\
\text { maintain aware- } \\
\text { ness, target spe- } \\
\text { cific behaviors } \\
\text { each time. }\end{array}$ & $\begin{array}{l}\text { Residents driving } \\
\text { onto post }\end{array}$ & $\begin{array}{l}\text { Periodically during } \\
\text { October } 1998 \\
\text { through March } \\
\text { 1999. Each mes- } \\
\text { sage ran two } \\
\text { weeks. }\end{array}$ & $\begin{array}{l}\text { This is an elec- } \\
\text { tronic reader- } \\
\text { board prominently } \\
\text { located at a major } \\
\text { intersection on } \\
\text { post. }\end{array}$ \\
\hline $\begin{array}{l}\text { Operation Energy } \\
\text { Poster containing } \\
\text { tips }\end{array}$ & $\begin{array}{l}\text { Target specific } \\
\text { behaviors and give } \\
\text { contact phone } \\
\text { numbers for re- } \\
\text { pairing energy- } \\
\text { inefficient fea- } \\
\text { tures of homes }\end{array}$ & Residents, mayors & $\begin{array}{l}200 \text { distributed } \\
\text { throughout the } \\
\text { campaign. Posted } \\
\text { at various loca- } \\
\text { tions (suggested } \\
\text { by residents), } \\
\text { given to each } \\
\text { housing area to } \\
\text { post or give out }\end{array}$ & \\
\hline Trifold brochure & $\begin{array}{l}\text { Introduce Opera- } \\
\text { tion Energy, moti- } \\
\text { vate participation, } \\
\text { show target be- } \\
\text { haviors }\end{array}$ & $\begin{array}{l}\text { Residents, may- } \\
\text { ors, personnel new } \\
\text { on post }\end{array}$ & $\begin{array}{l}5,000 \text { distributed } \\
\text { from October } \\
1998, \text { through } \\
\text { campaign. Deliv- } \\
\text { ered to housing } \\
\text { areas, given out at } \\
\text { fairs and training. }\end{array}$ & \\
\hline Articles in post & Introduce cam- & Residents & September 1998: & The May 1999 \\
\hline
\end{tabular}




\begin{tabular}{|c|c|c|c|c|}
\hline $\begin{array}{l}\text { Activity or In- } \\
\text { formation Piece }\end{array}$ & Purpose & Target Audience & $\begin{array}{l}\text { Time Frame and } \\
\text { distribution }\end{array}$ & Comments \\
\hline $\begin{array}{l}\text { housing newslet- } \\
\text { ter, "Under our } \\
\text { Roof" and Fort } \\
\text { Lewis newspaper, } \\
\text { "Guardian" }\end{array}$ & $\begin{array}{l}\text { paign, share re- } \\
\text { sults, motivate } \\
\text { residents, encour- } \\
\text { age competition, } \\
\text { remind people to } \\
\text { watch the video }\end{array}$ & & $\begin{array}{l}\text { October 1998; } \\
\text { May 1999, Octo- } \\
\text { ber } 1999\end{array}$ & $\begin{array}{l}\text { issue of "Under } \\
\text { Our Roof" also. } \\
\text { included a flier } \\
\text { showing dollars } \\
\text { saved and energy } \\
\text { tips }\end{array}$ \\
\hline $\begin{array}{l}\text { Three posters } \\
\text { showing savings } \\
\text { progress. One } \\
\text { poster showing } \\
\text { savings through } \\
\text { February } 1999 \text {, } \\
\text { one through June, } \\
\text { and one through } \\
\text { August } 1999\end{array}$ & $\begin{array}{l}\text { Encourage compe- } \\
\text { tition among } \\
\text { housing communi- } \\
\text { ties, motivate } \\
\text { residents to get } \\
\text { money back }\end{array}$ & All residents & $\begin{array}{l}\text { May 1999: July } \\
\text { 1999: September } \\
\text { 1999. One issue } \\
\text { was inserted in } \\
\text { "Under our Roof" } \\
\text { newsletter, which } \\
\text { is delivered to } \\
\text { each of } 3,500 \\
\text { housing units on } \\
\text { post; also given to } \\
\text { mayors and others } \\
\text { in other forums }\end{array}$ & \\
\hline $\begin{array}{l}\text { Updates at may- } \\
\text { ors' meetings }\end{array}$ & $\begin{array}{l}\text { Update mayors on } \\
\text { Operation Energy } \\
\text { progress, invite } \\
\text { their support, } \\
\text { answer questions, } \\
\text { give them materi- } \\
\text { als to hand out to } \\
\text { residents }\end{array}$ & $\begin{array}{l}\text { Mayors of each } \\
\text { housing area }\end{array}$ & $\begin{array}{l}\text { Starting in No- } \\
\text { vember 1998, con- } \\
\text { tinuing throughout } \\
\text { campaign, ap- } \\
\text { proximately quar- } \\
\text { terly }\end{array}$ & $\begin{array}{l}\text { Conducted by } \\
\text { Fort Lewis Re- } \\
\text { source Efficiency } \\
\text { Manager }\end{array}$ \\
\hline $\begin{array}{l}\text { Energy } \\
\text { booth/display at } \\
\text { Kids Fest - fair } \\
\text { for children }\end{array}$ & $\begin{array}{l}\text { Target children } \\
\text { and their parents } \\
\text { in a fun way, main- } \\
\text { tain awareness, } \\
\text { remind of target } \\
\text { behaviors to save } \\
\text { energy }\end{array}$ & Kids, parents & $\begin{array}{l}\text { April 1999. Thou- } \\
\text { sands of energy- } \\
\text { conservation } \\
\text { "giveaway" mate- } \\
\text { rials (refrigerator } \\
\text { magnets, pens, } \\
\text { activity books, } \\
\text { etc.) were do- } \\
\text { nated by local } \\
\text { utilities (Puget } \\
\text { Sound Energy and } \\
\text { Tacoma Power) } \\
\text { and given out }\end{array}$ & \\
\hline $\begin{array}{l}\text { Energy } \\
\text { booth/display at } \\
\text { Armed Forces Day } \\
\text { fair }\end{array}$ & $\begin{array}{l}\text { Target residents, } \\
\text { especially children } \\
\text { and parents }\end{array}$ & $\begin{array}{l}\text { Residents, espe- } \\
\text { cially kids and } \\
\text { parents }\end{array}$ & $\begin{array}{l}\text { May } 1999 . \\
\text { Same as above. }\end{array}$ & \\
\hline $\begin{array}{l}\text { Information made } \\
\text { available to com- } \\
\text { mand units for } \\
\text { troops }\end{array}$ & $\begin{array}{l}\text { Maintain aware- } \\
\text { ness through mili- } \\
\text { tary chain of } \\
\text { command }\end{array}$ & $\begin{array}{l}\text { Troops (some of } \\
\text { whom are on-post } \\
\text { residents) }\end{array}$ & $\begin{array}{l}\text { Throughout cam- } \\
\text { paign (up to com- } \\
\text { manders, not on a } \\
\text { regular basis) }\end{array}$ & $\begin{array}{l}\text { Lends authority if } \\
\text { they receive the } \\
\text { message through } \\
\text { their command } \\
\text { units }\end{array}$ \\
\hline Letters (from & Raise individual & High gas users & Began in June & Fort Lewis's ef- \\
\hline
\end{tabular}




\begin{tabular}{|c|c|c|c|c|}
\hline $\begin{array}{l}\text { Activity or In- } \\
\text { formation Piece. }\end{array}$ & Purpose & Target Audience & $\begin{array}{l}\text { Time Frame and } \\
\text { distribution }\end{array}$ & Comments \\
\hline $\begin{array}{l}\text { Housing) to high } \\
\text { gas users }\end{array}$ & $\begin{array}{l}\text { awareness of un- } \\
\text { usually high en- } \\
\text { ergy use and mo- } \\
\text { tivate to reduce }\end{array}$ & & 1999 & $\begin{array}{l}\text { fort: not part of } \\
\text { the campaign but } \\
\text { may have contrib- } \\
\text { uted to the de- } \\
\text { sired end result }\end{array}$ \\
\hline $\begin{array}{l}\text { Fliers (invitation } \\
\text { to attend a focus } \\
\text { group, with a } \\
\text { poster showing } \\
\text { savings by com- } \\
\text { munity) }\end{array}$ & $\begin{array}{l}\text { Invite residents } \\
\text { to attend a focus } \\
\text { group to help } \\
\text { evaluate campaign } \\
\text { effectiveness }\end{array}$ & $\begin{array}{l}\text { Residents of } \\
\text { three communities } \\
\text { ( } 600 \text { households } \\
\text { total) }\end{array}$ & August 1999 & $\begin{array}{l}\text { Mayors hand- } \\
\text { delivered these to } \\
\text { their communities. } \\
\text { The focus group } \\
\text { invitation at- } \\
\text { tracted only one } \\
\text { person, but the } \\
\text { poster on the } \\
\text { back of the invi- } \\
\text { tation was an- } \\
\text { other opportunity } \\
\text { to show residents } \\
\text { their savings com- } \\
\text { pared with other } \\
\text { communities. }\end{array}$ \\
\hline
\end{tabular}

Each quarter, every community's progress (cost savings or lack thereof) was displayed in various forums. Savings were not calculated based on comparison to every other community, but by comparing each community with its own energy use from the previous year. This approach made the comparison fair because Fort Lewis housing communities differ greatly in number of homes, house design, energy efficiency, and demographics of residents (e.g., number of children in the home).

Fort Lewis contributed partial printing and distribution of printed information materials, videotape production, on-site communication and coordination, raw data for energy and dollars saved, and certain incentives for turning in survey forms. This teamwork with the Army demonstrates cost sharing while supporting FEMP's approach of transferring technology and providing training and support.

\section{Results}

Campaign effectiveness was measured in two ways. First, energy use and costs were compared with the baseline use from FY98 to determine savings incurred after the campaign began. Second, residents were surveyed and interviewed to determine to what extent the campaign influenced behavior changes that led to the savings.

Table 2 summarizes the savings in Fort Lewis family housing for Fy99. Appendix B contains details.

Table 2. Energy Savings for Fort Lewis Family Housing (Compares the period September 1998 through August 199 with the previous period, September 1997 through August 1998)

\begin{tabular}{|l|l|l|l|}
\hline & Units Saved & Percent Saved & Dollars Saved \\
\hline Gas, raw data & $-331,439$ therms & $-12 \%$ & $-\$ 165,720$ \\
\hline Gas, corrected for & 83,375 therms $(8,338$ & $3 \%$ & $\$ 41,685$ \\
\hline
\end{tabular}




\begin{tabular}{|l|l|l|l|}
\hline & Units Saved & Percent Saved & Dollars Saved \\
\hline weather effects & $\mathrm{mBtu})$ & $7 \%$ & $\$ 88,702$ \\
\hline Electricity & $\begin{array}{l}4,233,000 \mathrm{kwh} \\
(14,442,996 \mathrm{mBtu})\end{array}$ & $10 \%$ & $\begin{array}{l}\$ 130,387 \text { (accounts } \\
\text { for weather correc- } \\
\text { tion) }\end{array}$ \\
\hline $\begin{array}{l}\text { TOTAL, Gas } \\
\text { (weather-corrected) } \\
\text { electricity }\end{array}$ & $14,451,334 \mathrm{mBtu}$ \\
\hline
\end{tabular}

kwh = kilowatt-hour; $m B+u=$ millions of British thermal units

The raw numbers for gas showed that residents actually used more gas in the year of the campaign than in the previous year. This increased use, however, reflected a cooler year and thus the need for more heat. Raw data by itself, therefore, masked the savings in gas use.

To make a fair comparison, the effects of weather must be ruled out. When weather was taken into account, the corrected results showed a gas energy savings of $3 \%$. Total energy savings in family housing were $10 \%$, accounting for weather, which exceeded the campaign goal of $3 \%$.

A mail survey of Fort Lewis residents $(1,231$ residents, or about $37 \%$ of occupied homes) showed that the campaign was moderately effective in promoting behavior change. Table 3 summarizes the results. Appendix $C$ shows the survey results in detail.

Table 3. Summarized Survey Responses (Some total more than $100 \%$ because some questions allowed more than one response)

\begin{tabular}{|l|l|}
\hline Question & Responses \\
\hline 1. Have you heard about Operation Energy? & $\begin{array}{l}\text { No, } 56 \% \\
\text { Yes, 40\% } \\
\text { Not sure, 4\% }\end{array}$ \\
\hline 2. How did you become aware of the campaign? & $\begin{array}{l}\text { Print materials, 66\% } \\
\text { Other people, 14\% } \\
\text { Video, 7\% } \\
\text { Not sure, 5\% } \\
\text { Other, } 4 \% \text { (this survey, community meeting, my } \\
\text { command, etc.) } \\
\text { Kids Fair, 2\% } \\
\text { Readerboard, 1\% }\end{array}$ \\
\hline $\begin{array}{l}\text { 3. Have you heard that each housing community } \\
\text { that saves will receive an incentive award? }\end{array}$ & $\begin{array}{l}\text { Yes, 58\% } \\
\text { No, 42\% }\end{array}$ \\
\hline far? Which community is saving the most energy so & $\begin{array}{l}\text { Don't know, 61\% } \\
\text { Beachwood/Lakewood, 15\% } \\
\text { Davis Hill, 11\% } \\
\text { All others, less than } 5 \%\end{array}$ \\
\hline $\begin{array}{l}\text { 5. Check the things you started doing after Op- } \\
\text { eration Energy began in September. }\end{array}$ & $\begin{array}{l}\text { No change, } 8 \% . \\
\text { Heating and cooling: Began turning down thermostat } \\
\text { at night or when gone, 47\%, began closing windows } \\
\text { when heat was on, 23\%, cleaned or changed furnace } \\
\text { filters, 14\%, others, less than 6\%. } \\
\text { Lighting: Starting turning off outside lights, 19\%. } \\
\text { Washing: began cleaning the lint trap in the dryer, } \\
14 \%, \text { began running full load in dishwasher, 12\%, }\end{array}$ \\
\hline
\end{tabular}




\begin{tabular}{|c|c|}
\hline Question & Responses \\
\hline & $\begin{array}{l}\text { began using cold water for washing clothes, } 13 \% \text {, } \\
\text { others } 12 \% \text { or less. } \\
\text { Fridge: Adjusted temp, } 13 \% \text {. }\end{array}$ \\
\hline 6. What caused you to start doing those things? & $\begin{array}{l}\text { Right thing to do, } 34 \% \\
\text { Set a good example for kids, } 24 \% \\
\text { Other (raised that way, etc.), } 13 \% \\
\text { Wanted more comfortable conditions, } 10 \% \\
\text { All others (habit/upbringing, etc.), less than } 10 \%\end{array}$ \\
\hline $\begin{array}{l}\text { 7. Does anything make it impractical to save en- } \\
\text { ergy? }\end{array}$ & $\begin{array}{l}\text { My house wastes energy, } 45 \% \\
\text { Other (inefficient house, problems with repairs, } \\
\text { already saving, etc.), } 26 \% \\
\text { All others, less than } 9 \%\end{array}$ \\
\hline 8. Which housing community do you belong to? & $\begin{array}{l}\text { Old/New Hillside, } 30 \% \\
\text { All others, less than } 15 \% \text { each }\end{array}$ \\
\hline 9. How long there? & $\begin{array}{l}1 \text { yeart, } 52 \% \\
7 \text { months to a year, } 12 \% \\
3 \text { months or less, } 15 \% \\
4-6 \text { months, } 14 \%\end{array}$ \\
\hline $\begin{array}{l}\text { 10. What will it take to motivate residents to } \\
\text { keep using energy wisely? }\end{array}$ & $\begin{array}{l}\text { Most commonly mentioned: information/awareness } \\
(40 \%) \text {, disincentives ( } 27 \%) \text {, incentives (20\%), Army } \\
\text { to make improvements }(16 \%)\end{array}$ \\
\hline
\end{tabular}

Highlights of these results appear below.

- Awareness. Less than half (40\%) of respondents had heard about the campaign. Awareness rose slightly after having been there at least a year.

- Channels. By far the most common way people became aware of the campaign was through print media: fliers, newspapers, newsletters, and posters. Other commonly mentioned channels were other people (family members, mayors, commanders, etc.) and the video.

- Comprehension. Of those who were aware of the campaign, the majority $(58 \%)$ had heard of the incentives, but most $(61 \%)$ said they did not know which community had saved the most money. Interestingly, the majority of respondents who guessed which community had saved the most money chose their own community, which was usually not true. Only $11 \%$ of respondents knew which community had actually saved the most.

- Behavior change. Only $8 \%$ of respondents said they had made no changes since the campaign began. Of those who said they did change, the most common action taken was turning down the thermostat at night or when gone (47\%), which was the top targeted behavior of the campaign.

- Motivation. When asked why they did these things, the top answer was that it was the right thing to do (34\%). This was closely followed by the desire to set a good example for one's children (24\%).

- Barriers. The overwhelming barrier to efficient energy use was houses that waste energy because of poor construction or age (45\%). Consistent with this answer, the "other" option for this question generated many strongly worded complaints about leaky windows and doors, poor insulation, and inefficient heat systems. Interestingly, very few people chose the "uncaring" responses of "doesn't make a difference" or "too busy to think about it (each $2 \%$ ).

- Demographics. About half $(52 \%)$ of respondents had been on post more than one year, with the rest there for a shorter amount of time. The responses represented each housing area quite well; the percent of survey respondents from each area was within five percentage points or less of the same area's population. 
- Sustaining change. When asked what it would take for residents to continue to use energy wisely, increasing information and awareness was the most frequently mentioned, followed by disincentives, incentives, and improvements that the Army should make. The most common disincentives mentioned were paying the utility bill or paying over a capped amount. Respondents were less specific about the nature of the incentives. Consistent with the answers to other questions. the most common improvement recommended was to upgrade housing conditions. Other categories received less than $5 \%$ each, including monitor or meter use, appeal to values, nothing or already saving, don't know or not sure, and other.

Of those who were aware of the campaign, all but $8 \%$ said they were now doing one or more energy-efficient things that they had not done before. The most commonly mentioned were turning down the thermostat at night or when gone from the home, closing windows and doors when the heat was on, and turning off the outside lights during the day.

Most people were motivated by the desire to "do the right thing" and to set a good example for their children. They were less motivated by other factors, such as the potential of receiving a financial incentive for their community or competition with other communities on post.

Residents overwhelmingly identified the most significant barrier to energy efficiency as poorly constructed or inefficiently weatherized houses that waste heat.

When asked what it would take to continue energy efficiency in family housing, the most common response was a financial disincentive-in the form of making people pay for their utilities (or paying the excess when energy use reaches a certain predetermined level). Other repeated suggestions were incentives, reminders/education, better housing, and providing residents with personalized energy use information).

The experiences and lessons learned from this campaign and from a complementary one at a Marine base in Arizona were used as a basis for a publication, "Handbook for Promoting BehaviorBased Energy Efficiency in Military Housing" (McMakin et al., 1999). The August 1999 handbook is available through DOE's Energy Efficiency and renewable Energy Clearinghouse in Virginia.

\section{Conclusions and Discussion}

- Savings of $10 \%$ were achieved over a year's time. Nevertheless, the potential for even greater savings is evident. According to the Resource Efficiency Manager, Fort Lewis residential housing accounts for $40 \%$ of the installation's energy costs. More can and should be done to meet federal energy goals of $35 \%$ reduction in energy consumption in federal facilities by 2010 from 1985 levels (Presidential Executive Order 13123, June 1999). Behavior-based change must continue to be measured and emphasized in conjunction with housing upgrades and technology improvements.

- Many residents were not aware of the campaign. If people don't know which actions to target and don't see the results of their savings, there is little motivation to change behavior. Some of the lack of awareness can be explained by personnel turnover. About half the survey respondents had lived there for less than a year, so they would have been exposed to only limited information about the campaign. Information dissemination also was limited by post resources and policies. Fort Lewis's Resource Efficiency Manager is involved with all energy efficiency efforts on post, including administrative and troop areas, and including physical upgrades such as lighting retrofits. It is very difficult for one person to give residential housing the level of attention it deserves. Scout leaders on post, for example, were interested in adapting their activities to complement 
Operation Energy, but the leaders required more time and resources than the Resource Efficiency Manager was able to give. The same was true of school involvement, though there are five elementary schools on post.

- Because of Fort Lewis budget policies that were not revealed until the end of the campaign, the incentive that was promised to communities for saving energy did not materialize. This unfortunate situation meant that something that was supposed to be a key motivator-a reward to communities-was not delivered. Interestingly, survey respondents said that they were far more motivated by the need to "do the right thing" and to model good habits for their kids than they were by the promised incentive. However, when asked what would be most motivational for all residents, the top two responses were incentives and disincentives. This disconnect could indicate that people like to think that they act out of socially responsible motives but that everyone else needs a stronger incentive.

- As described in the literature, Fort Lewis residents overwhelmingly cited thermal comfort as a concern. People repeatedly described problems with their houses, such as leaky windows and doors, that wasted energy and made conditions uncomfortable for them and their families. This finding reinforces the need to more widely distribute the videotape, which addresses these concerns. Fort Lewis's practice of tracking gas use in homes with individual meters and contacting the highest users apparently has been effective in identifying homes with efficiency problems that may be correctable. Officials need to communicate more effectively about plans for upgrading and repairing homes. Officials should also ensure that requests by residents for weatherization upgrades (e,g., caulking and weatherstripping repair) are filled to the extent possible, and make sure people understand the limitations of what the home repair contractor is allowed to do. Furthermore, installation officials need to be aware that residents may not be inclined to save energy unless living conditions and pay are improved. As one respondent stated, "There is very little people can do. The quarters are very old and what we do doesn't make a difference." In addition, some people are not inclined to save energy if they don't feel that the Army cares enough about them or their homes to meet basic needs. As one person said, "Unfortunately, the last thing a solider is concerned with is whether his house is energy efficient. Our Army is in horrible shape, no money for training or good pay. When we treat our soldiers better, then they will care."

- As mentioned, FEMP is funding a complementary project at a Marine base in Arizona. That project provides the opportunity to test some different approaches that appeared promising in the literature (e.g., use of a pre- and post-test, direct involvement with children and their parents through base daycare providers, disincentives in the form of "tickets" placed on offenders' doors, personal contact of residents by base energy monitors, and a regular column in the base newsletter). For the hot southwest environment, different behaviors are emphasized-efficient use of air conditioning and water. Combining the findings from the Arizona project with those from Fort Lewis should yield a substantial baseline of research-based approaches for other, similar situations.

\section{Recommendations}

Based on the Fort Lewis campaign findings, the following strategies are recommended for efficiency programs at military installations:

- Tailor actions and approaches to the military installation's people, situation, and culture. What works at one location may not work at another. The handbook, "Promoting Behavior-Based Energy 
Efficiency in Military Housing" (McMakin et al., 1999) describes a variety of options and shows examples of information materials that can be adapted for specific situations.

- To raise awareness, use direct contact with residents as much as possible (including direct mail and personal interaction), and repeat the messages and targeted behaviors often. This is especially important in a military setting, where frequent moves are common.

- Emphasize the energy-efficiency benefits of personal comfort, improved health, and convenience-from a less drafty home with cleaner air, for example. People resent the perception of deprivation often associated with conservation, especially in the military where they feel they are already making many sacrifices. Use the term "efficiency" rather than "conservation."

- Tap into peoples' socially responsible values-pride in their own energy-efficient lifestyles, their desire to do the right thing, and their inclination to set a good example for their children. Through values don't always translate into actions, people resent the implication that they are poor citizens or parents.

- Address information gaps or misinterpretations in peoples' "mental models" that may affect the actions they take. People may be reluctant to purchase compact fluorescent lights, for example, if they mistakenly view them as the old-fashioned, long fluorescent tubes rather than the new, natural-light models that fit in standard light fixtures. As another example, people may use their programmable thermostats inefficiently if they don't understand how to adjust them.

- Make sure factors that could affect the campaign results-including the installation's policy constraints, staff and resource availability, and ongoing housing upgrades that affect energy efficiency-are clearly understood and factored into the campaign design and goals.

The literature, combined with findings from the fort Lewis campaign, suggest the following approaches that could not be applied adequately at Fort Lewis. Additional work should be conducted to test them in field situations.

- The preliminary literature review for this project emphasized that without support systems in place to aid behavioral change and overcome barriers, stated values often fail to be translated into actions (Walker et al., 1997). To institutionalize long-term change, it may be best to combine a variety of motivators, including appeal to environmental and parental responsibility, direct outreach to kids, written commitments, incentives, and disincentives. One way to enhance institutionalization may be to include behavior-based energy efficiency requirements as part of the housing agreement that new residents sign. Another potential strategy is to use the newcomer's orientation to expose people to information, including requiring viewing of a video demonstrating the targeted actions.

As suggested by many residents, give out mock bills or some other kind of feedback that shows the amount of energy costs they are using over time, perhaps comparing costs with those of a typical range of houses off post. Remind them in these mock bills what they can do to save energy. The more these "bills" can be personalized (individual homes if possible, neighborhoods if not), the more effective they will be. As one Fort Lewis resident said, "Make them aware of their individual energy use and let them know if it's reasonable. In my three years here. I have never seen anything that would let me know."

Interestingly, the use of mock bills may also help create cognitive dissonance in cases where residents think they're saving more energy than they actually are. People like to think that they are 
good energy consumers, whether they are or not. In the Fort Lewis study, survey respondents consistently implied that that they themselves had good conservation habits but that other people needed stronger incentives to save. In other words, if any energy was being wasted, it was caused by other people, not themselves.

This feeling of self-altruism is a common phenomenon. For example, as mentioned, other studies have shown cases where energy consumers claimed to have taken a wide range of conservation actions, but, when energy use was measured, these statements were found to be considerable exaggerated (McDougall et al., 1981). A study in Perth, Western Australia, explicitly used cognitive dissonance to correct a similar situation. High electricity consuming households reduced energy use when the inconsistency between these families' attitude toward conservation and their actual electrical use was pointed out (Kantola, Syme \& Campbell, 1984).

For the mock billing approach to be tested, homes would need to be individually metered. The off-base comparison homes and demographics would need to be as similar to the on-base homes as possible, so that family member behavior became the salient characteristic in energy use. Mock bills should use the characteristics of effective energy bills found in previous studies (McMakin et al., 1999).

- Consider financial incentives and disincentives for energy use. To the extent allowed by existing metering and Congressional mandates, consider placing a cap on energy use (different for different house designs) and requiring personal payment when energy costs exceed the cap. If allowed by budgeting policies, use part of the money saved from energy conservation for financial incentives for communities or individuals.

One Fort Lewis respondent suggested a combined incentive/disincentive approach that may make the payment concept more palatable. Each family would receive a reasonable utility compensation in advance, which would vary based on the number of occupants and type of home. Residents would use the compensation to pay for their utilities. If they used more than the allotted amount, they would pay out of pocket. If they used lessenergy than the allotted compensation allowed for, however, they could keep that portion of the money. This way, residents could work toward their own "award" each month. Fort Lewis already uses this approach for off-post housing; it is worth testing on post.

- Work directly through children to influence parents, as well as educating and motivating kids themselves. School programs targeting environmental and energy themes, especially when kids involve parents in activities in the home, have been shown effective in getting family members to adopt certain behaviors (e.g., Harrigan, 1991).

\section{References}

Costanzo, M., Archer, D., Aronson, M., \& Pettigrew, T. (1986). Energy conservation behavior: The difficult path from information to action. American Psychologist, 41 (5), 521-528.

Dennis, M.L., Soderstrom, E.J., Koncinski, W.S., Jr., \& Cavanaugh, B. (1990). Effective dissemination of energy-related information. American Psychologist, 45 (10), 1109-1117.

Harrigan, M. (1991). Moving consumers to choose energy efficiency. The Alliance to Save Energy: Washington, $D C$. 
Harrigan, M. Kempton, W., \& Ramakrishna, V. (1995). Empowering customer energy choices: A review of personal interaction and feedback in energy efficiency programs. The Alliance to Save Energy: Washington, D.C.

Hayes, S.C., \& Cone, J.D. (1977). Reducing residential electrical energy use: Payments, information and feedback. Journal of Applied Behavior Analysis, 10 (3), 425-435.

Kantola, S.J., Syme, G.J., \& Campbell, N.A. (1984). Cognitive dissonance and energy conservation. Journal of Applied Psychology, 69 (3), 416-421.

McDougall, G.H.G., Claxton, J.D., Ritchie, J.R.B., \& Anderson, C.D. (1981). Consumer energy research: A review. Journal of Consumer Research, 8 (3), 343-354.

MCMakin, A.H., Lundgren, R.E., \& Malone, E.L: (1999). Handbook for promoting behaviorbased energy efficiency in military housing. Prepared for the U.S. Department of Energy by Pacific Northwest National Laboratory.

Neuman, K. (1986). Personal values and commitment to energy conservation. Environment and Behavior, 18 (1), 53-74.

Siero, F.W., Bakker, A.B., Dekker, G.B., \& van den Burg, M.T.C. (1996). Changing organizational energy consumption behavior through comparative feedback. Journal of Environmental Psychology, 16, 235-246.

Stern, P.C. (1992). What psychology knows about energy conservation. The American Psychologist, 47 (10), 1224-1232.

Walker, M.K. Stevenson, L., and Heerwagen, J. (1997). Institutionalizing energy efficiency as a public value: $A$ literature review of the social sciences and communications disciplines. Letter report prepared for the Federal Energy Management Program, submitted to Jerry Dion, March 24, 1997.

Winett, R.A., Leckliter, I.N., Chinn, D.E., Stahl, B., \& Love, S.Q. (1985). Effects of television modeling on residential energy conservation. Journal of Applied Behavior Analysis, 18, 33-44. 
APPENDIX A

Examples of Information Materials 


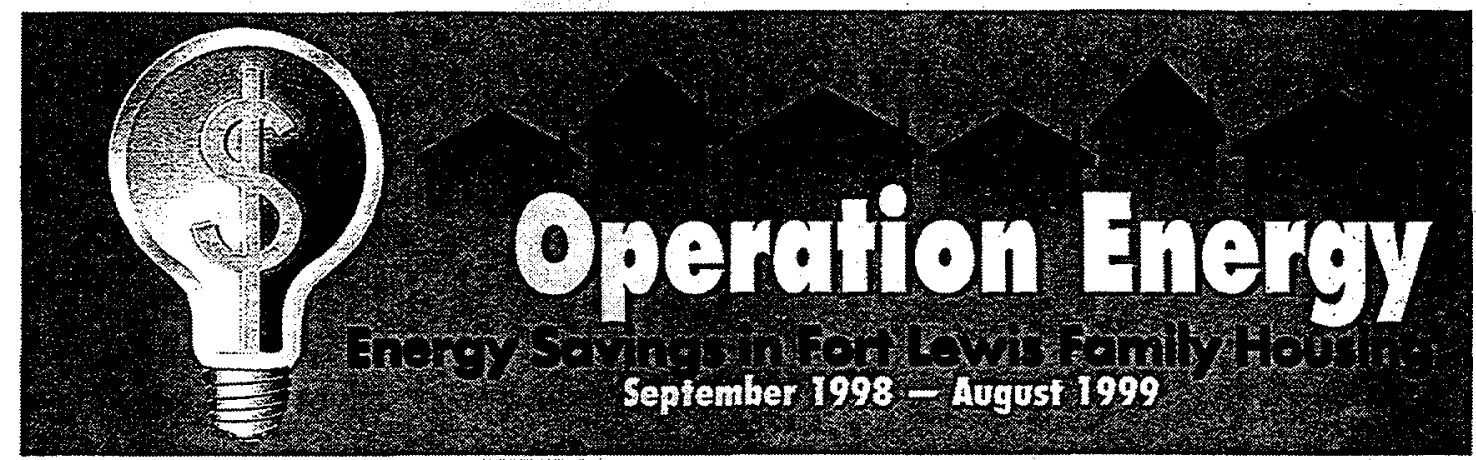

Beachwood
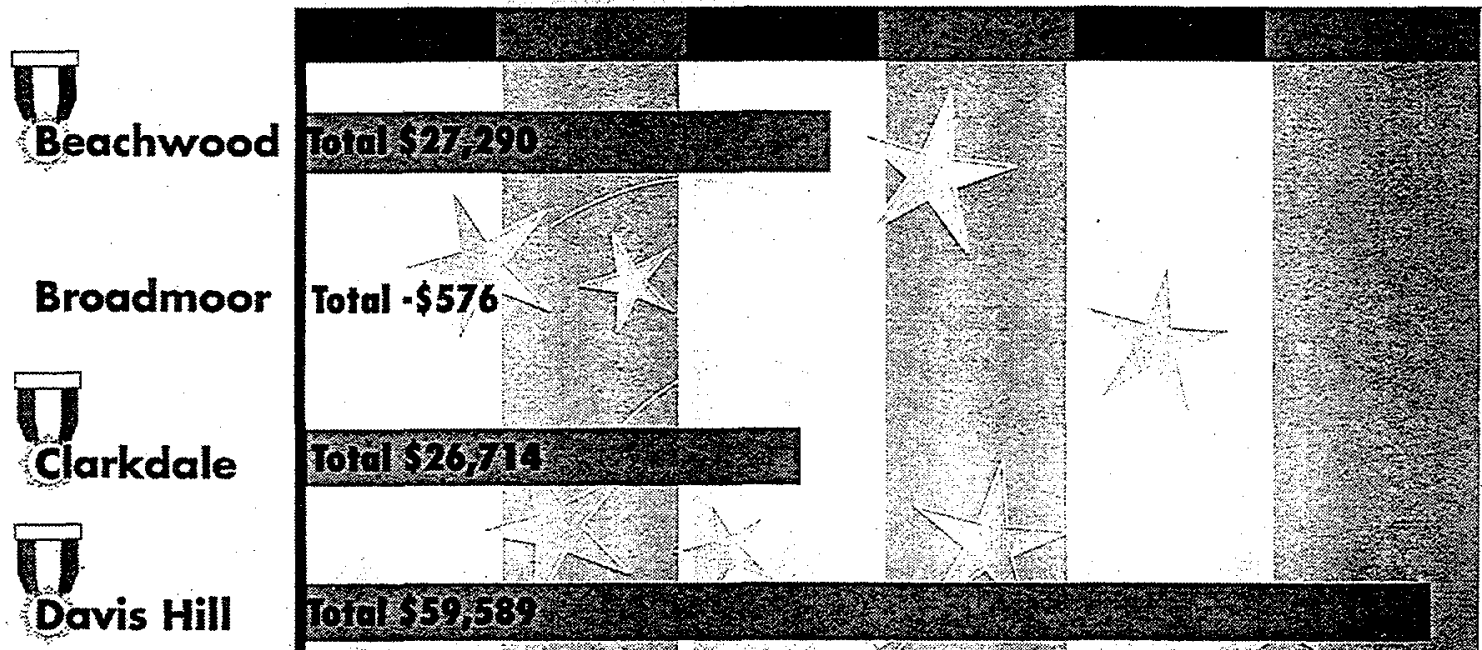

Eagle View

tre

Eyergreen

Greenwood

Hillside

is Madigan

in

Parkway

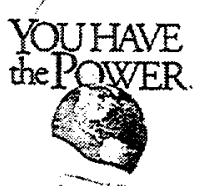

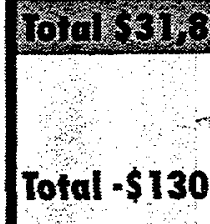

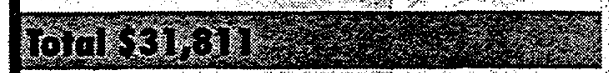

1010 00,025

Yo7 $\$ 4,800$

Ptal $\$ 1,150$
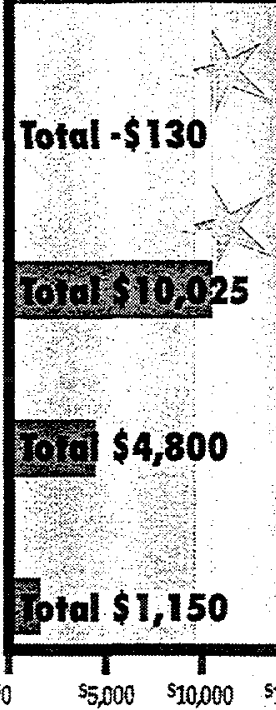

Total Energy

for more information about Operotion Energy?

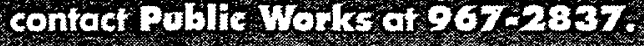




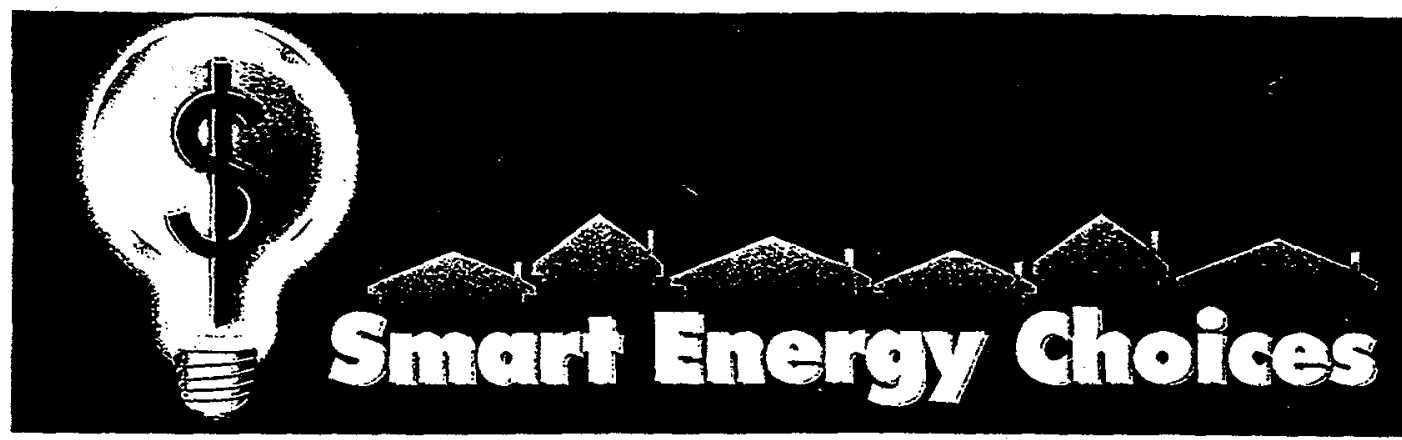

\section{Operation Energy Tips for Families Living on Post at Fort Lewis}

Use

hear wisely. Managing

your thermostat is the most important

thing you can do to use energy wisely! Keep

the thermostat at 70 degrees or lower. Turn down

the thermostat at night to 65 degrees or lower when

you go to bed or leave your house for more than four

hours. Keep doors and windows closed when the heat is

on. Close drapes and blinds in the evening and at night. Minimize

the use of portable heaters. Keep air outlets and radiators clean. Don't " d" "at" your tamily. You will feel more comfortable if

you keep draffy air from seeping into your home. Check for air leakage around doors and windows. If cold air is seeping in, contact your Family Housing Work Order Desk. Gei a bright idea. Use lights only when you need them. Turn lights off in unoccupied areas, including porch lights when you go to bed. Buy light bulbs that are 60 watts or less. Even better, get energy-saving compact fluorescent lights - they last much longer and you won't have to change them as often! 1, Mas? nisely. Heating water takes a lot of energy. Make sure the dishwasher and clotheswasher have full loads before running them. Use the "air dry" selting on the dishwasher. Wash clothes in cold woter when possible, and rinse them in cold water. Keep your cool. Hot air can be hard on clothing. Use the air dry setting on the dryer when possible. This will help reduce shrinkage and make clothes last longer. to keep your dryer from working too hard and overheating, clean the lint filter after every load. And keep the outside exhaust vent clean. iake charge of your findge. Set your refrigerator temperature at 37 to 40 degrees and your freezer at 0 to 5 degrees. Close the door quickly after you select an item.

Breathe easier. Filters that are clean help keep dust out of the air. Change or clean filters monthly. Get new fitters from the SelfHelp Store.

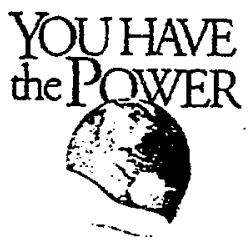

For more information about wise energy use, contact Public Works at $967-2837$. 

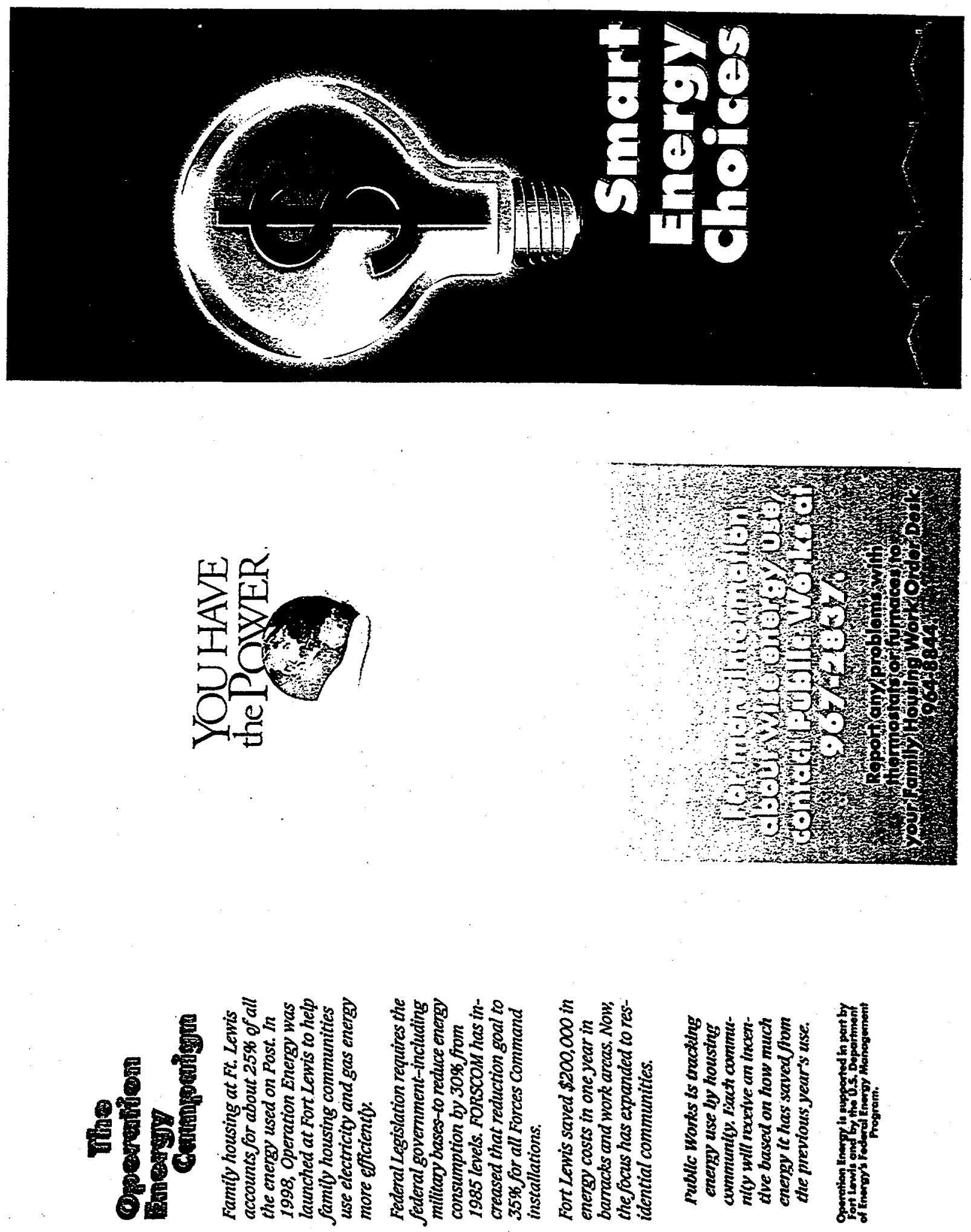


\section{Tips for Families Living on Post at Fort Lew/s}

Use heat wisely. Managing your thermostat is the most important thing you can do to use energy wisely! Keep the thermostat at 70 degrees or lower. Turn down the thermostat at night to $65 \mathrm{de}$ grees or lower when you go to bed or leave your house for more than four hours. : Keep doors and windows closed when the heat is on. : Close drapes and blinds in the evening and at night. : Minimize the use of portable heaters. $\$$ Keep air outlets and radiators clean.

Breathe easier. Filters that are clean help keep dust out of the air. Change or clean filters monthly. Get new filters from the Self-Help Store.

Don't "draft" your family. You will feel more comfortable if you keep drafty air from seeping into your home. Check for air leakage around doors and windows. If cold air is seeping in, contact your Family Housing

Work Order Desk.

Get a bright idea. Use lights only when you need them. Turn lights off in unoccupied areas, including porch lights when you go to bed. Buy light bulbs that are 60 watts or less. Even better, get energy-saving compact fluorescent lights - they last much longer and you won't have to change them as often!

Wash wisely. Heating water takes a lot of energy. Make sure the dish-washer and clotheswasher have full loads before running them. Use the "air dry" setting on the dishwasher. Wash clothes in cold water when possible, and rinse them in cold water.

Keep your cool. Hot air can be hard on clothing. Use the "air dry" setting on the dryer when possible. This will help reduce shrinkage and make clothes last longer. To keep your dryer from working too hard and overheating, clean the lint filter after every load. And keep the outside exhaust vent clean.

Take charge of your fridge. Set your refrigerator temperature at 37 to 40 degrees and your freezer at 0 to 5 degrees. Close the door quickly after you select an item. 


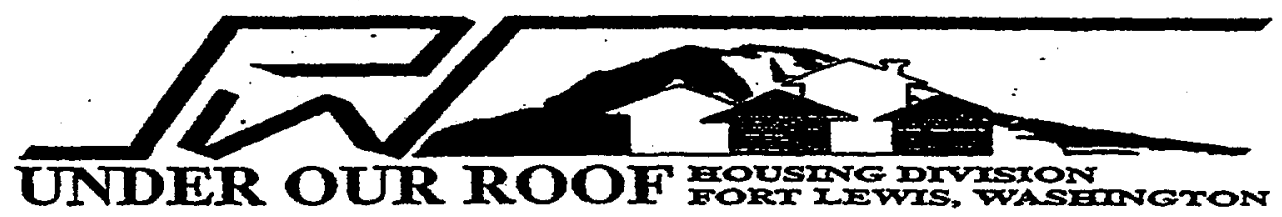

Volume 4 Issue 5

SEP/OCT 98

\section{OPERATION ENERGY}

by Andrea McMakin

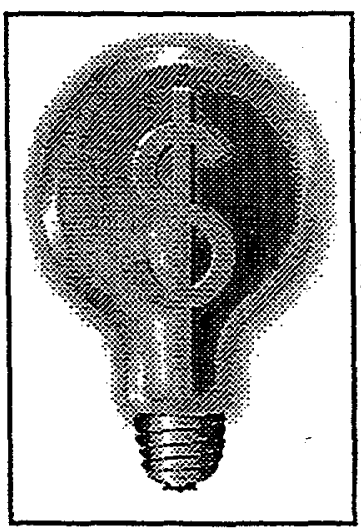

As part of a new "Operation Energy" campaign, Family Housing members can look forward to receiving an incentive for using energy wisely. The campaign, which begins this month, highlights simple ways family members can use energy efficiently in onpost housing.

\section{Operation}

Energy

builds on our success with barracks and troop administrative areas, where we saved about $\$ 200,000$ in energy costs in fiscal year 1997. For Family Housing, each neighborhood will receive an incentive equivalent to how much energy the community saved each month, compared with last year's energy consumption.

Housing residents in several communities were consulted for ideas to develop the campaign. Residents chose the campaign logo (light bulb containing a dollar sign) and slogan "(Smart Energy Use"). Residents also provided a valuable "reality check" on an initial set of energy-saving actions and contributed ideas for involving people and communicating results. Scout leaders are planning ways to involve scouts in Operation Energy as a way to eam merit badges and meet community service requirements. This month, the video "In Search of the Energy Bandit" will begin running on Channel 2. Residents from five neighborhoods - Beachwood, Broadmoor, Davis Hill, Evergreen, and Greenwood - are featured in the video. Beginning in October, Public Works will report how much money each conmunity has saved in energy use. Residents are also invited to give energy tip , which will be published each month.

The campaign is supported in part by the US Department of Energy's Federal Energy Management Program and may become a model for other military installations. For more information about Operation Energy or to contribute an energy tip, contact Charles Howell at Public Works at 967-2837.

\section{Energy Tips for Families Living on Post at Fort Lewis:}

Turn your thermostat down to 65 degrees when you go to bed or leave your house for more than four hours.

Keep doors and windows closed when the heat is on.

* Change or clean furnace filters monthly. Get new filters at the Self Help Store.

4t If cool air is seeping in through old weather stripping or caulking around doors and windows, contact the Work Order Desk at 964-8844.

\& When you need a new light bulb, check the Commissary and $P X$ for compact fluorescent lights, which last ten times longer than regular light bulbs.

* Turn off all outside lights during daylight hours.

\& Run full loads in your dishwasher and clothes washer.

it Use the "air dry" and "energy saver" features on the dishwasher.

Use cold water for rinsing clothes, and use the "air dry" setting on the dryer.

4) Clean the lint trap on the dryer before every load.

it Set your refrigerator temperature at 37 to 40 degrees and your freezer at 0 to 5 degrees. Close the door quickly after you have selected you food item.

\section{TOWING ABANDONED AND DISABLED VEHICLES by MSG John Jackson}

The Housing Area Managers have been given the authorization to have abandoned and disabled vehicles towed. The abandoned or disabled vehicle will be marked first. The registered owner will then have nine days to either register the vehicle if it lacks a registration, or remove it from the housing area if it is disabled. If action is not taken within the nine-day period, the vehicle will be towed at the registered owner's expense. 


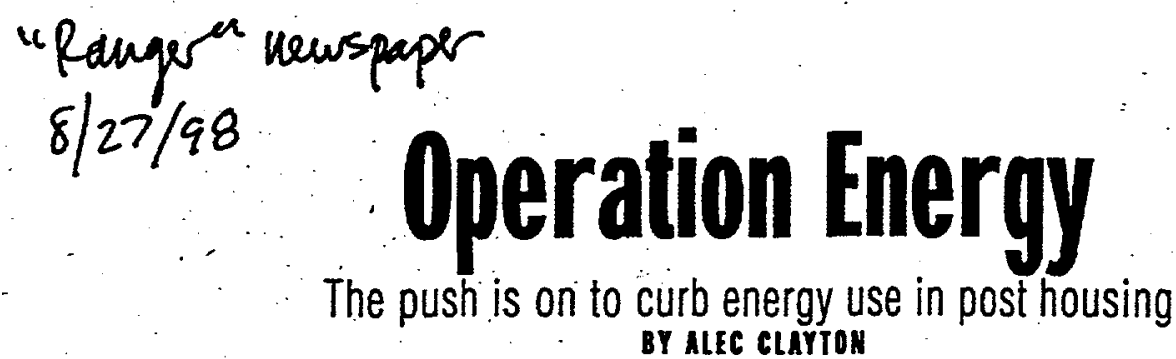

cot

ort Lewis, and all military installations, must reduce energy consumption by 30 percent, based on 1985 levels, by the year 2005. Energy use on post costs about $\$ 12$ million a year according to Charles Howell from Public Works. "We have been doing different kinds of energy programs and have increased our target to a 35 percent savings," Howell says. "We've been concentrating on the troop side, getting soldiers to monitor energy use in the barracks, and now we want to focus on housing."

In one year, energy conservation programs in the barracks and administrative buildings haye saved Fort Lewis $\$ 200,000$, says Aridrea McMakin of PNW National Lab, a contractor working with Fort Lewis and the Department of Energy.

Similar savings in housing may be a much larger challenge. Housing accounts for around 25 percent of ail energy consumption on post. or around $\$ 3$ million in a year. On the job, a commander can mandate nurning off the lights when you leave - not so at home. "When you're not paying the bill, you don't see the bill. But Fort Lewis pays for it," McMakin says. "Relying on residents to make behavioral changes is a particular challenge, because family housing residents don't currently pay their own utility bills and thus lack the incentive of lower utility bills."

To meet this challenge, Fort Lewis is conducting a new campaign called Operation Energy. The objective is to increase energy efficiency in on-post family housing through activities family members can do themselves. McMakin says this is the only campaign they have found nationwide that focuses on energy efficiency in Army family

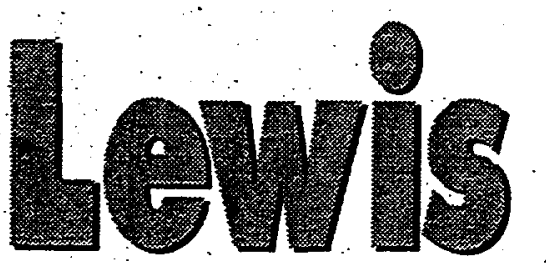

housing, using no-cost or low-cost activities family members can do themselves (as opposed to upgrades and technology). Operation Energy, which begins in September and is expected to run through December, focuses on simple activities such as turning down the thermostat at night, turning porch lights off during the day, and keeping filters clean. The cam-
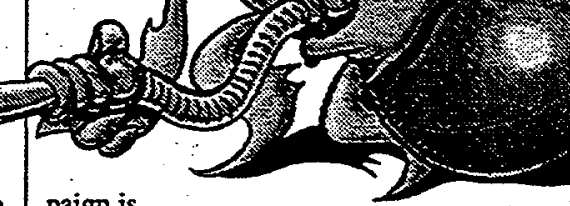

paign is

partly supported by the U.S. Department of Energy's Federal Energy Management Program. DOE is interested in the results and wants to make this campaign a model for other military bases. Results from the campaign, along with support materials including a locally produced video, are expected to be used by DOE nationwide.

To help meet this challenge, Fort Lewis has taken the unusual and innovative approach of offering incentives to families who conserve energy based on the amount of money saved each month. Howell promises there will be things like block parties and picnics for communities that reduce energy use.

McMakin says other groups want to get involved. "Scouting leaders," she says, "have expressed a high degree of interest in folding energy efficiency activities into their programs. We've talked about having them create an that would be used in the campaign. They also may go door-to-door handing out fliers or other information, and may be asking people what they do to conserve energy." She also expressed the hope that community mayors would get into the act. Operation Energy has created a video called "In Search of the Energy Bandit" which will be aired in October, National Energy Awareness Month. The video features a cartoon character, the energy bandit. "He's a sneaky bad guy who runs around sucking up energy, creating drafts and creating havoc in people's homes. We tell people how to outsmart him by doing things around the house to use energy efficiently, McMakin says. $\mathrm{R}$

\section{Energy saving tips}

I Use heat wisely: Keep the thermostat at 70 or lower; turn it down to 65 or lower when you go to bed or leave the house for more than four hours. Keep doors and windows closed when the heat is on. Close drapes or blinds in the evening. Do

not use electric heaters; they are a fire hazard. Arrange furniture and draperies away from registers so air can circulate. Keep outlets and radiators clean.

- Breathe easier: Change or clear fiters monthly. Get new filters from the Self-Help Store.

- Don't "draft" your family: Check for air leaks around doors and windows. If cold air is seeping in, contact your Family Housing Work Order Desk.

n Get a bright idea: Use lights onty when you need them. Turn out porch lights when you go to bed. Use 60-watt or less bulbs or long lasting, energy-saving compact fluorescent lights.

Wash wisely: Make sure the dishwasher and clotheswasher have full loads before running them. Use the "air dry" setting on the dishwasher. Wash clothes in warm or cool water when possible and rinse in cool water.

Keep your cool: Use the air dry setting on your dryer when possible to help reduce shrinkage and make clothes last longer. Clean the fiter after every load and keep the outside exhaust clean.

Take charge of your 'fridge: Set the temperature at 35 to 40 degrees and the freezer at 0 to 5 degrees. Close the refrigerator door as quickly as you can. $\mathbf{R}$ 


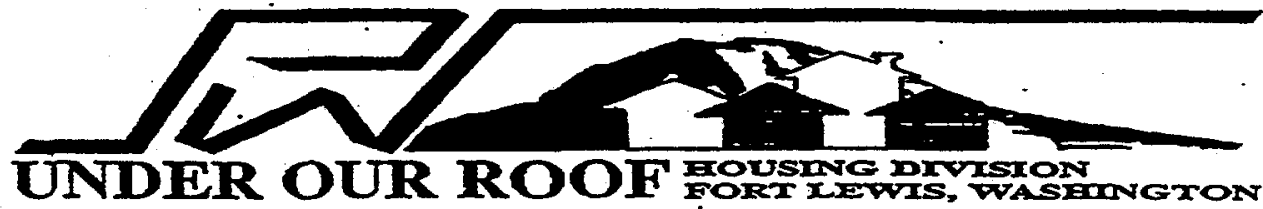

Volume 5 Issue 3

MAY/JUN 99

\section{FAMILY HOUSING TO GET $\$ \$ \$$ \\ BACK FOR SMART ENERGY USE}

by Launa Morasch and Charles Howell

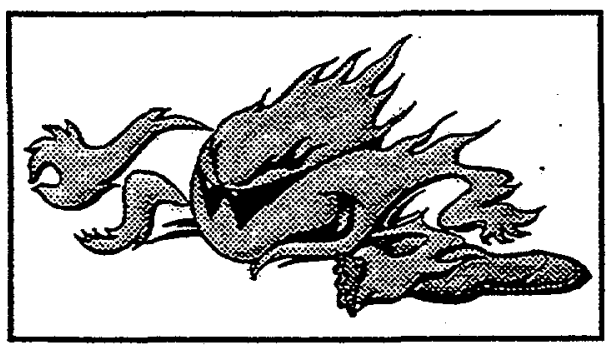

Since September, four family housing areas have saved big bucks by making smart energy choices. In the five months since September 1998, here is what residents have saved, as compared with last year's use: Beachwood $(\$ 14,895)$, Davis Hill $(\$ 18,728)$, Greenwood (\$433), and Madigan $(\$ 1,512)$.

Some of these savings are very impressive! And even better, each community will get part of its energy savings back in a block party or other community event when the Operation Energy campaign ends this fall. The more energy dollars each housing area saves, the more its'residents get back

If your housing area shows no savings yet, there is still time to earn money back for your community. Savings can change dramatically from month to month by hundreds and even thousands of dollars. The Public Works Energy Management Office is monitoring energy use monthly. The best way to save consistently is for family members to make smart energy choices every day (see tips below).

Learn more about Operation Energy on Channel 2 , where you. will see your friends and neighbors in action against the dreadful Energy Bandit! Residents also learned about the campaign at the Kids Fest in April, on reader boards, at community forums, monthly mayor's meetings, and in fliers and posters around the. installation. For more information, contact your mayor or the Public Works Energy Management Office at 967-2837.
How to Save Energy Dollars in Family Housing How many of these things do YOU do?

Indoor Temperature and Comfort. Turn thermostat down to 65 degrees when going to bed or leaving the house for more than four hours. Keep doors and windows closed when heat is on. Change or clear furnace filters monthly (get new filters at the Self-Heip Store). Call the Work Order Desk at 964-8844 to repair weather stripping, caulking, or broken thermostats.

Lights. Buy compact fluorescent lights at the Commissary and PX. They use one quarter the energy of regular bulbs and last ten times longer. Turn off inside lights when not in use. Turn off all outside lights during daylight hours.

Kitchen. Wait until you have a full load to run your dishwasher. Use "air dry" and "energy saver" settings on the dishwasher. Set your refrigerator's temperature at 37 to 40 degrees and your freezer at 0 to 5 degrees. Close the door quickly, and make sure the door is closed tightly.

Washer and Drver. Run full loads. Use cold water for rinsing clothes. Use the "air dry" setting on the dryer. Clean the lint trap before loading the dryer.

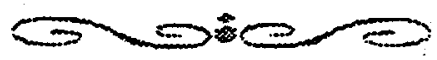

\section{NEWS FROM YOUR VET}

Do you have pets going to Hawaï? Owners are advised to contact the Veterinary Services at 967-3988 at least seven months prior to departure for new State of Hawaii importation regulations for pets. Pet vaccinations and health certificates are required for interstate and international travel. A copy of orders is required for health certificates.

Stray pets found on Fort Lewis and McChord AFB are held for three working days at the Stray Animal Holding Facility located at the Veterinary Treatment Facility (Building 9988 at Old Madigan). If not claimed, pets are pat up for adoption or euthanized. 


\section{We know you have a lot to say.}

So say it.

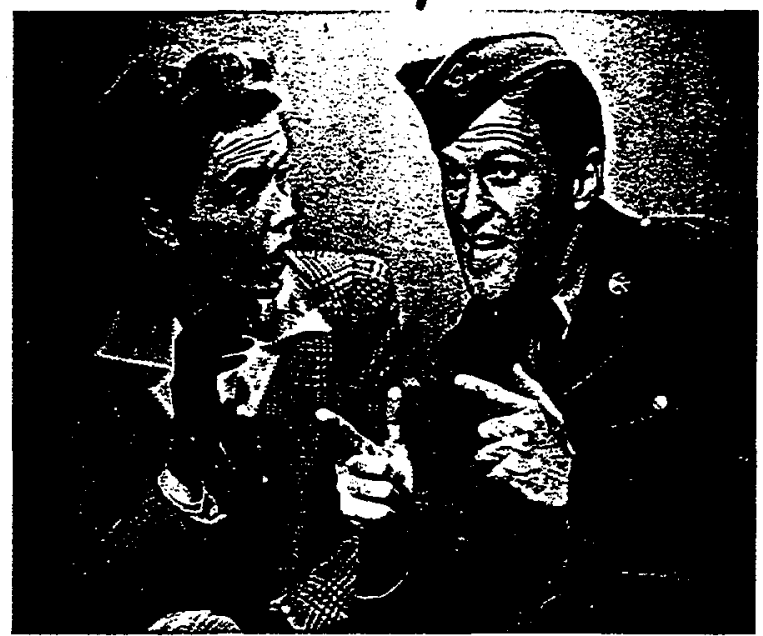

If you live in Family Housing at Fort Lewis, you may have heard about OPERATION ENERGY.

Since last fall, we've been telling residents how they can use energy wisely in their homes... while staying comfortable... and getting an incentive award for their communities.

Now, we want to hear from you.

Did it work?

Are people doing anything differently?

What really motivates people to use energy wisely?

What should we do next?

You talk. We listen. Free refreshments.

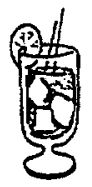

Not a bad way to spend an hour.

Family Housing Residents Invited

Friday, August 13, 199

7:00 - 8:00 p.m.

Family Resource Center

Hosted by Public Works. Information: $967-2837$ 


\section{"In Search of the Energy Bandit"}

Final Script, August 11, 1998

\section{Training Videotape to be Used with the Operation Energy Campaign for Fort Lewis Family Housing}

\begin{tabular}{|c|c|c|}
\hline Video & Audio/Graphic Effects & Narration \\
\hline $\begin{array}{l}\text { Camera searching along } \\
\text { window frames, seen through } \\
\text { circle like telescope }\end{array}$ & Character music & \\
\hline $\begin{array}{l}\text { Title: "In Search of the } \\
\text { Energy Bandit" }\end{array}$ & $\begin{array}{l}\text { Character music fades } \\
\text { out }\end{array}$ & \\
\hline $\begin{array}{l}\text { Mom and son walking up } \\
\text { sidewalk to house, reaching } \\
\text { front door, and if time, } \\
\text { opening it (show flag on } \\
\text { house). }\end{array}$ & Happy, relaxed music & $\begin{array}{l}\text { At Fort Lewis, our homes are } \\
\text { safe and comfortable ... }\end{array}$ \\
\hline Family doing puzzle on table & Happy music continues & $\begin{array}{l}\text {... A place to relax and have } \\
\text { fun with our families. Our } \\
\text { homes are so important to us } \\
\text { that we guard against anyone } \\
\text { breaking in to steal our } \\
\text { possessions. }\end{array}$ \\
\hline Energy bandit creeping & $\begin{array}{l}\text { "Sneaky" character } \\
\text { music }\end{array}$ & $\begin{array}{l}\text { But there is one unsavory } \\
\text { character lurking around } \\
\text { inside our homes; most of the } \\
\text { time ... the ENERGY } \\
\text { BANDIT. }\end{array}$ \\
\hline $\begin{array}{l}\text { Energy bandit "vacuuming" } \\
\text { energy }\end{array}$ & $\begin{array}{l}\text { Character music } \\
\text { continues, then fades. }\end{array}$ & $\begin{array}{l}\text { The Energy Bandit runs } \\
\text { around stealing energy, } \\
\text { creating drafts, and generally } \\
\text { wreaking havoc, when it } \\
\text { comes to energy efficiency. } \\
\text { But you can outsmart the } \\
\text { energy bandit - home by } \\
\text { home. }\end{array}$ \\
\hline $\begin{array}{l}\text { Playground with house in } \\
\text { background. Housing names } \\
\text { superimposed on scene. }\end{array}$ & Background music & $\begin{array}{l}\text { Family housing at Fort Lewis } \\
\text { costs about } \$ 3 \text { million dollars } \\
\text { annually for electricity and } \\
\text { gas energy. So, by using } \\
\text { energy wisely, you and your } \\
\text { family can make a BIG } \\
\text { difference. }\end{array}$ \\
\hline Mom turning down knob in & & YOU are the best weapon \\
\hline
\end{tabular}




\begin{tabular}{|c|c|c|}
\hline Video & Audio/Graphic Effects & Narration \\
\hline $\begin{array}{l}\text { freezer (show hand on knob } \\
\text { close-up only) }\end{array}$ & & $\begin{array}{l}\text { against the Energy Bandit. } \\
\text { It's easy ... and you won't } \\
\text { have to sacrifice comfort. }\end{array}$ \\
\hline $\begin{array}{l}\text { Dad and mom changing } \\
\text { lightbulb [very quick clip, } \\
\text { taking the old bulb out] }\end{array}$ & & $\begin{array}{l}\text { By making smart energy } \\
\text { choices around the house, you } \\
\text { can reduce the amount of } \\
\text { energy that the Bandit is } \\
\text { getting away with. }\end{array}$ \\
\hline $\begin{array}{l}\text { Energy Bandit moving across } \\
\text { screen, holding sign saying } \\
\text { "Temperature" }\end{array}$ & Character music & \\
\hline \multirow[t]{2}{*}{ Setting back the thermostat } & & $\begin{array}{l}\text { One of the most important } \\
\text { things you can do is to control } \\
\text { the temperature in your home. } \\
\text { If you do only one thing to } \\
\text { save energy, this should be the } \\
\text { one. }\end{array}$ \\
\hline & & $\begin{array}{l}\text { Keep the thermostat at } 70 \\
\text { degrees or lower to heat your } \\
\text { home during the day. Turn it } \\
\text { down to } 65 \text { degrees at night, } \\
\text { or if you'll be gone for more } \\
\text { than four hours. }\end{array}$ \\
\hline $\begin{array}{l}\text { Words: } \\
5 \text { degrees less at night }=\$ 500 \\
-\$ 3,000 \text { saved per month, for } \\
\text { a typical housing community }\end{array}$ & & $\begin{array}{l}\text { Turning your thermostat down } \\
5 \text { degrees at night saves a } \\
\text { substantial amount of energy } \\
\text { and money. If everyone in a } \\
\text { typical housing area did this, } \\
\text { they could save five hundred } \\
\text { to three thousand dollars each } \\
\text { month in energy costs, for that } \\
\text { neighborhood alone! }\end{array}$ \\
\hline $\begin{array}{l}\text { Mom guiding son inside } \\
\text { from patio on Big Wheel, } \\
\text { closing sliding glass door. }\end{array}$ & & $\begin{array}{l}\text { Your furnace has to work } \\
\text { harder if doors are left open. } \\
\text { Make sure doors are firmly } \\
\text { closed when someone enters } \\
\text { or leaves. }\end{array}$ \\
\hline $\begin{array}{l}\text { Mom shutting heating vent in } \\
\text { ceiling. }\end{array}$ & & $\begin{array}{l}\text { Close the heating vents in } \\
\text { rooms that don't get much } \\
\text { use. }\end{array}$ \\
\hline $\begin{array}{l}\text { Mom, carrying baby, putting } \\
\text { heater in closet. }\end{array}$ & & $\begin{array}{l}\text { Minimize the use of portable } \\
\text { heaters. They use a lot of } \\
\text { energy and can be a fire } \\
\text { hazard. }\end{array}$ \\
\hline Dad taking out filter and & & It's important to clean or \\
\hline
\end{tabular}




\begin{tabular}{|c|c|c|}
\hline Video & Audio/Graphic Effects & Narration \\
\hline $\begin{array}{l}\text { looking at it. Vacuuming it, } \\
\text { then hosing it off. }\end{array}$ & & $\begin{array}{l}\text { replace your furnace filter } \\
\text { monthly. Not only does this } \\
\text { help your furnace run more } \\
\text { efficiently, it reduces the } \\
\text { amount of dust in the air. } \\
\text { Less dust means a healthier } \\
\text { home with fewer allergies, } \\
\text { and hey, maybe even a little } \\
\text { less housework. When your } \\
\text { furnace filter wears out, get a } \\
\text { new one at the Self-Help } \\
\text { Store. }\end{array}$ \\
\hline $\begin{array}{l}\text { Words on screen: } \\
\text { Family Housing Work Order } \\
\text { Desk } \\
\text { and phone number }\end{array}$ & & $\begin{array}{l}\text { Report any problems with } \\
\text { thermostats or furnaces to the } \\
\text { Family Housing Work Order } \\
\text { Desk. }\end{array}$ \\
\hline $\begin{array}{l}\text { Energy Bandit puling sign } \\
\text { that says "Drafts" }\end{array}$ & Character music & \\
\hline Mom cranking window shut. & & $\begin{array}{l}\text { Open windows can cause } \\
\text { uncomfortable drafts when } \\
\text { it's cool outside. Make sure } \\
\text { your windows are closed. }\end{array}$ \\
\hline $\begin{array}{l}\text { Full shot of camera moving } \\
\text { around inside window frame } \\
\text { (one without shades). }\end{array}$ & & $\begin{array}{l}\text { If you can still feel air leaking } \\
\text { in through closed windows } \\
\text { and doors, your sealant } \\
\text { materials may be worn out. }\end{array}$ \\
\hline $\begin{array}{l}\text { Technician ripping off old } \\
\text { weather-stripping, screwing } \\
\text { new weather-strip into door } \\
\text { frame and squeezing out new } \\
\text { caulking in window. }\end{array}$ & & $\begin{array}{l}\text { Old weather-stripping can be } \\
\text { replaced, and caulking can be } \\
\text { reapplied, as the maintenance } \\
\text { technician is doing here. This } \\
\text { will make your home much } \\
\text { more warm and cozy, } \\
\text { eliminating those drafty spots. } \\
\text { Contact the Family Housing } \\
\text { Work Order Desk for this } \\
\text { service. }\end{array}$ \\
\hline $\begin{array}{l}\text { Energy Bandit pulling screen } \\
\text { that says "Lighting." }\end{array}$ & Character music & \\
\hline $\begin{array}{l}\text { Mom and son entering house } \\
\text { and turning on light in living } \\
\text { room. [Cut before Mom } \\
\text { walks out of scene. We want } \\
\text { to imply that she is staying in } \\
\text { the room with the light on.] }\end{array}$ & & $\begin{array}{l}\text { Using light wisely helps beat } \\
\text { the Energy Bandit. Turn } \\
\text { lights on only in rooms where } \\
\text { you need them. }\end{array}$ \\
\hline
\end{tabular}




\begin{tabular}{|c|c|c|}
\hline Video & Audio/Graphic Effects & Narration \\
\hline $\begin{array}{l}\text { Dad leaving house to go to } \\
\text { work, seeing porch light, } \\
\text { turning it off, then coming } \\
\text { down front steps. }\end{array}$ & 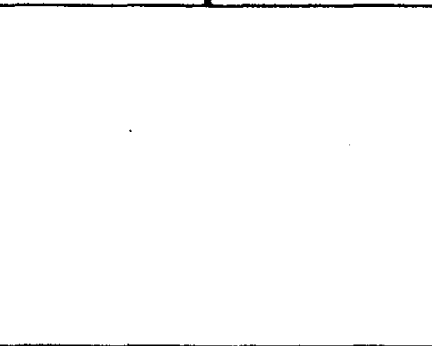 & $\begin{array}{l}\text { Of course outdoor lighting is } \\
\text { necessary for safety and } \\
\text { security, but don't forget to } \\
\text { turn off your porch light when } \\
\text { you go to bed ... or at least } \\
\text { when you get up in the } \\
\text { morning. }\end{array}$ \\
\hline $\begin{array}{l}\text { Mom and Dad changing light } \\
\text { bulb and turning on light }\end{array}$ & & $\begin{array}{l}\text { You might want to check all } \\
\text { the light fixtures in the house } \\
\text { - after turning off the lights, } \\
\text { of course-to see if the right } \\
\text { wattage bulbs are installed. It } \\
\text { is unsafe to have a } 100 \text {-watt } \\
\text { bulb in a fixture that is } \\
\text { marked for } 60 \text { watts. }\end{array}$ \\
\hline $\begin{array}{l}\text { Dad, holding son, at } \\
\text { Commissary checkout } \\
\text { counter buying CFL. }\end{array}$ & & $\begin{array}{l}\text { Check the Commissary and } \\
\text { PX for energy-efficient } \\
\text { compact fluorescent lights. } \\
\text { These lights last ten times } \\
\text { longer than regular bulbs, so } \\
\text { you won't have to change } \\
\text { them as often. }\end{array}$ \\
\hline $\begin{array}{l}\text { Energy Bandit pulling screen } \\
\text { that says "Laundry." }\end{array}$ & Character music & \\
\hline $\begin{array}{l}\text { Mom putting clothes in } \\
\text { washer, turning knob to cool. }\end{array}$ & & $\begin{array}{l}\text { The laundry is a great place to } \\
\text { put a lid on the Energy } \\
\text { Bandit. Do full loads } \\
\text { of laundry. Use cold } \\
\text { water for washing } \\
\text { whenever possible, } \\
\text { and always use cold } \\
\text { water in the rinse } \\
\text { cycle. }\end{array}$ \\
\hline $\begin{array}{l}\text { Mom shaking out mesh shirt, } \\
\text { putting it in dryer, turning to } \\
\text { "air fluff," turning on. }\end{array}$ & & $\begin{array}{l}\text { To dry lighter-weight items, } \\
\text { use the air-dry setting. If you } \\
\text { need to use heat, dry several } \\
\text { loads of laundry one after } \\
\text { another. It takes a lot of } \\
\text { energy to heat up a cold dryer. }\end{array}$ \\
\hline $\begin{array}{l}\text { Mom pulling out lint screen } \\
\text { and cleaning it off. }\end{array}$ & & $\begin{array}{l}\text { Clean the lint screen in the } \\
\text { dryer between each load. This } \\
\text { way, your dryer will not have } \\
\text { to work as hard to produce } \\
\text { heat. }\end{array}$ \\
\hline Mom cleaning exhaust vent. & & And keep the outside exhaust \\
\hline
\end{tabular}




\begin{tabular}{|c|c|c|}
\hline Video & Audio/Graphic Effects & Narration \\
\hline & & vent clean. \\
\hline $\begin{array}{l}\text { Energy Bandit pulling screen } \\
\text { that says "Kitchen." }\end{array}$ & Character music & \\
\hline $\begin{array}{l}\text { Mom opening fridge door, } \\
\text { turning down temp controls, } \\
\text { closing door. }\end{array}$ & & $\begin{array}{l}\text { The energy bandit loves to } \\
\text { lurk around your kitchen. } \\
\text { Check your refrigerator and } \\
\text { freezer. They may be too } \\
\text { cold. Set your refrigerator at } \\
\text { a level that reaches about } 37 \\
\text { to } 40 \text { degrees. And push the } \\
\text { "energy saver" button if you } \\
\text { have one. }\end{array}$ \\
\hline $\begin{array}{l}\text { Mom turning down freezer } \\
\text { temp, closing door. }\end{array}$ & & $\begin{array}{l}\text { Set your freezer temperature } \\
\text { at mid-level, reaching about } \\
\text { zero to five degrees. }\end{array}$ \\
\hline $\begin{array}{l}\text { Girl opening fridge door, } \\
\text { taking milk carton out, } \\
\text { closing door, pouring milk }\end{array}$ & & $\begin{array}{l}\text { And we don't want all that } \\
\text { cold air leaking out. Select } \\
\text { your items quickly, and then } \\
\text { shut the door. }\end{array}$ \\
\hline $\begin{array}{l}\text { Dad putting last glass and } \\
\text { plate in dishwasher, pushing } \\
\text { air dry, and water saver } \\
\text { buttons. }\end{array}$ & 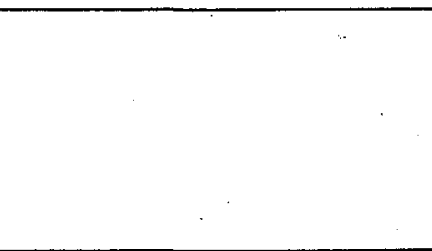 & $\begin{array}{l}\text { Always run the dishwasher } \\
\text { with a full load, and use the } \\
\text { air dry setting. Use the "water } \\
\text { saver" feature if your } \\
\text { dishwasher has one. }\end{array}$ \\
\hline $\begin{array}{l}\text { Family playing on floor, cat } \\
\text { walks in. }\end{array}$ & Happy music & $\begin{array}{l}\text { Making smart energy choices } \\
\text { helps you and your family. } \\
\text { Your home can be more } \\
\text { comfortable because of fewer } \\
\text { drafts ... }\end{array}$ \\
\hline $\begin{array}{l}\text { Mom pushing "cool" button } \\
\text { on washer. }\end{array}$ & & $\begin{array}{l}\ldots \text { more hot water for other } \\
\text { things when you use cold } \\
\text { water for clothes washing ... }\end{array}$ \\
\hline Dad vacuuming filter. & & $\begin{array}{l}\ldots \text { and less dust particles } \\
\text { when furnace filters are } \\
\text { cleaned or replaced regularly. }\end{array}$ \\
\hline \multicolumn{3}{|l|}{$\begin{array}{l}\text { Clip from the Colonel. } \\
\text { Superimposed on beginning } \\
\text { of clip: "Colonel [name] } \\
\text { Director of Public Works." }\end{array}$} \\
\hline $\begin{array}{l}\text { Energy bandit with a "no" } \\
\text { symbol superimposed (circle } \\
\text { with line through it). }\end{array}$ & Character music & $\begin{array}{l}\text { So remember the battle plan } \\
\text { to eliminate the energy bandit. }\end{array}$ \\
\hline $\begin{array}{l}\text { Mom turning down } \\
\text { thermostat }\end{array}$ & & $\begin{array}{l}\text { Turn down the thermostat at } \\
\text { night ... }\end{array}$ \\
\hline Dad pulling out furnace filter & & ... clean or replace furnace \\
\hline
\end{tabular}




\begin{tabular}{|c|c|c|}
\hline$\overline{\text { Video }}$ & Audio/Graphic Effects & Narration \\
\hline and looking at it. & & filters monthly ... \\
\hline Dad turning off porch light & & $\begin{array}{l}\ldots \text { reduce unnecessary } \\
\text { lighting... }\end{array}$ \\
\hline $\begin{array}{l}\text { Mom shutting sliding glass } \\
\text { door after son comes in. }\end{array}$ & & $\begin{array}{l}\ldots \text { and keep doors and } \\
\text { windows shut in cool weather. }\end{array}$ \\
\hline $\begin{array}{l}\text { "You Have the Power" icon } \\
\text { (hand holding globe) }\end{array}$ & & $\begin{array}{l}\text { You have the power to make a } \\
\text { difference! }\end{array}$ \\
\hline $\begin{array}{l}\text { Icon of lightbulb with words } \\
\text { superimposed: For more } \\
\text { information, contact: } \\
\text { Your Community Mayor } \\
\text { Or } \\
\text { Public Works Department, } \\
\text { Phone number }\end{array}$ & & $\begin{array}{l}\text { For more information about } \\
\text { making your home energy } \\
\text { efficient and comfortable, } \\
\text { contact your community } \\
\text { mayor or the Public Works } \\
\text { Department. }\end{array}$ \\
\hline $\begin{array}{l}\text { Credits } \\
\text { This video was made } \\
\text { possible with support from } \\
\text { Fort Lewis and the U.S. } \\
\text { Department of Energy's } \\
\text { Federal Energy Management } \\
\text { Program. } \\
\\
\text { Operation Energy Campaign, } \\
1998\end{array}$ & & \\
\hline
\end{tabular}


APPENDIX B

Energy Savings
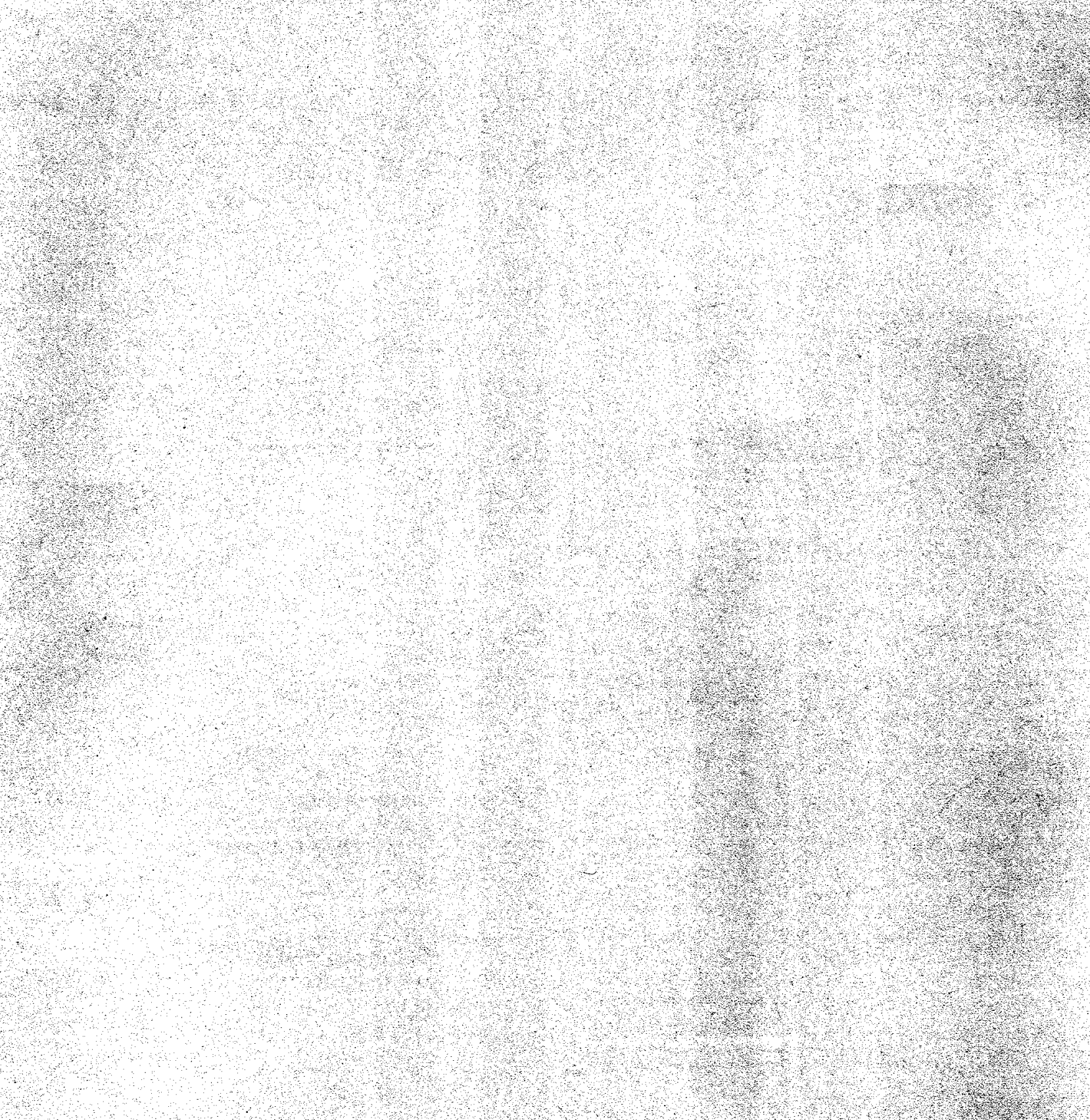

he
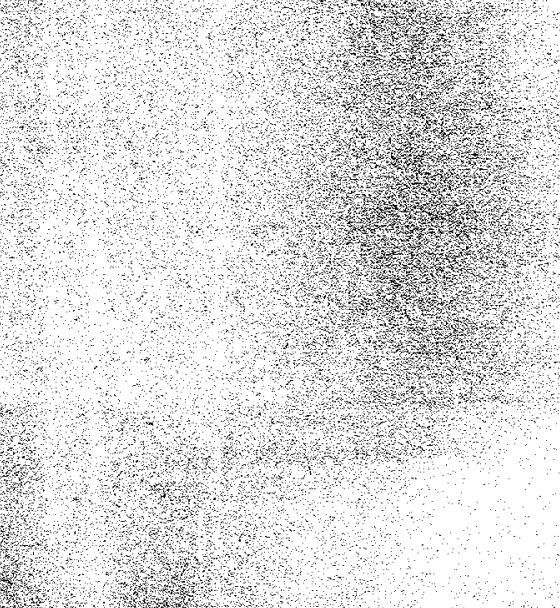
Energy Savings in Fort Lewis Family Housing, Dollars, September 98 - August 99 (weather-corrected)

\begin{tabular}{|c|c|c|c|c|c|c|c|c|}
\hline & Sep-98 & Oct-98 & Nov-98 & Dec-98 & Jan-99 & Feb-99 & Mar-99 & Apr-99 \\
\hline Beach/Lake & $2,244.00$ & $1,390.00$ & $2,453.00$ & $(4,846.00)$ & $12,213.00$ & $1,440.00$ & 410.00 & $(1,896.00)$ \\
\hline Broadmoor & $(1,048.00)$ & $1,262.00$ & $2,259.00$ & $(3,283.00)$ & $3,445.00$ & $(3,289.00)$ & $(352.00)$ & $(438.00)$ \\
\hline Clarkdale & 634.00 & 395.00 & 512.00 & $(4,894.00)$ & $11,192.00$ & $(9,633.00)$ & $(2,121.00)$ & 902.00 \\
\hline Davis Hill & $3,933.00$ & $4,963.00$ & $3,313.00$ & $(2,748.00)$ & $10,900.00$ & $1,016.00$ & 382.00 & $1,234.00$ \\
\hline Eagleview & $(19.00)$ & 88.00 & 261.00 & $(99.00)$ & 142.00 & $(497.00)$ & $(285.00)$ & $(267.00)$ \\
\hline Evergreen & $(889.00)$ & 777.00 & $(188.00)$ & $2,301.00$ & 59.00 & $(2,739.00)$ & $5,828.00$ & $(2,090.00)$ \\
\hline Greenwood & 340.00 & $(739.00)$ & $4,000.00$ & $(625.00)$ & 797.00 & $(1,944.00)$ & $(2,664.00)$ & $(2,045.00)$ \\
\hline Hillside & $3,187.00$ & $5,108.00$ & $1,102.00$ & $(14,954,00)$ & $13,372.00$ & $(7,946.00)$ & $(3,958.00)$ & $(6,209.00)$ \\
\hline Madigan & $(116.00)$ & 57.00 & 19.00 & $(149.00)$ & $1,691.00$ & 191.00 & 185.00 & 418.00 \\
\hline Parkway & $(847.00)$ & $(799.00)$ & 10.00 & $(2,093.00)$ & $3,189.00$ & 120.00 & $(210.00)$ & $(99.00)$ \\
\hline \multirow[t]{2}{*}{ TOTAL } & $7,419.00$ & $12,502.00$ & $13,741.00$ & $(31,390.00)$ & $57,000.00$ & $(23,281.00)$ & $(2,785.00)$ & $(10,490.00)$ \\
\hline & May-99 & Jun-99 & Jul-99 & Aug-99 & TOTAL & v & & \\
\hline Beach/Lake & $1,551.00$ & $6,864.00$ & $4,301.00$ & $1,166.00$ & $27,290.00$ & & & \\
\hline Broadmoor & 581.00 & 475.00 & $(289.00)$ & 101.00 & $(576.00)$ & & & \\
\hline Clarkdale & $(604.00)$ & 276.00 & 546.00 & 105.00 & $26,714.00$ & . & & . \\
\hline Davis Hill & $1,711.00$ & $5,405.00$ & $14,516.00$ & $14,964.00$ & $59,589.00$ & & & \\
\hline Eagleview & $(133.00)$ & $(29.00)$ & $(34.00)$ & $(10.00)$ & $(882.00)$ & & & \\
\hline Evergreen & $7,433.00$ & $6,856.00$ & $7,618.00$ & $6,845.00$ & $31,811.00$ & & & \\
\hline Greenwood & $1,861.00$ & 459.00 & $1,103.00$ & $(673.00)$ & $(130.00)$ & & & \\
\hline Hillside & $11,006.00$ & $3,367.00$ & $4,772.00$ & $1,178.00$ & $10,025.00$ & & & \\
\hline Madigan & 482.00 & $1,965.00$ & 208.00 & $(151.00)$ & $4,800.00$ & & & \\
\hline Parkway & 83.00 & $1,245.00$ & 428.00 & 123.00 & $1,150.00$ & & & \\
\hline TOTAL & $23,971.00$ & $26,883.00$ & $33,169.00$ & $23,648.00$ & $130,387.00$ & & & \\
\hline
\end{tabular}

Savings by Month and Energy Type, Sept 98 - August 99 (weather-corrected)

\begin{tabular}{rccc}
\multicolumn{2}{c}{ gas } & \multicolumn{3}{c}{ elec } & \multicolumn{2}{c}{ TOTAL } \\
Sep-98 & $(135.00)$ & $7,554.00$ & $7,419.00$ \\
Oct-98 & $15,051.00$ & $(2,549.00)$ & $12,502.00$ \\
Nov-98 & $15,700.00$ & $(1,959.00)$ & $13,741.00$ \\
Dec-98 & $(3,642.00)$ & $(27,748.00)$ & $(31,390.00)$ \\
Jan-99 & $8,976.00$ & $48,024.00$ & $57,000.00$ \\
Feb-99 & $(11,444.00)$ & $(11,837.00)$ & $(23,281.00)$ \\
Mar-99 & $(4,538.00)$ & $1,753.00$ & $(2,785.00)$ \\
Apr-99 & $(4,580.00)$ & $(5,910.00)$ & $(10,490.00)$ \\
May-99 & $17,147.00$ & $6,824.00$ & $23,971.00$ \\
Jun-99 & $4,111.00$ & $22,772.00$ & $26,883.00$ \\
Jul-99 & $3,025.00$ & $30,144.00$ & $33,169.00$ \\
Aug-99 & $2,014.00$ & $21,634.00$ & $23,648.00$ \\
TOTAL & $\mathbf{4 1 , 6 8 5 . 0 0}$ & $\mathbf{8 8 , 7 0 2 . 0 0}$ & $130,387.00$
\end{tabular}




\section{Process for Accounting for Weather Effects in Energy-Use Data}

A billing analysis comparison approach is the standard approach for estimating energy savings from energy conservation programs. The utility billing approach estimates energy savings by establishing an energy consumption baseline or baseline model using 12 or more months of energy consumption (the energy source used for heating and cooling) for the housing area of interest. That baseline consumption is compared with actual consumption after implementation of the conservation project.

One limitation of a simple comparison of the monthly consumption, however, is that it does not account for other factors that can affect energy consumption and vary over time, such as weather. For example, we know that the amount of natural gas or electricity consumed for heating depends on the outside air temperature - the colder it is, the more heating required to maintain the same comfort level in the residence. So, if the outdoor temperatures in the winter months used to establish the energy use baseline were significantly colder than the months used to determine the actual energy use, the predicted energy use based on the baseline model would be significantly greater than actual energy use, artificially inflating the "real" energy savings derived from the project.

A multivariate regression analysis is one technique to account for the differences in weather conditions between the pre- and the post-project periods. The basic data requirements for this approach are housing community level monthly natural gas consumption, the dates of the meter reading, and daily average outdoor air temperature representative of the site.

The baseline statistical model is constructed by regressing the daily energy consumption against the daily average temperature (or heating degree day) for the billing period to determine the baseline energy performance model. Once the appropriate baseline model has been determined for the housing project, the post-installation energy use is estimated by running the baseline model using post-project daily temperature and operating conditions as model input. The energy savings are calculated by comparing the differences between the actual energy use and the energy use predicted by the model for the same time period. 
APPENDIX $C$

Survey Results 
September 1, 1999

Dear family housing resident:

The Public Works and Housing Divisions at Fort Lewis would like to get your feedback and opinions about the Operation Energy campaign. The campaign focuses on things residents can do to use energy wisely in family housing.

WHAT WE'RE ASKING YOU TO DO-Please take a few moments to complete the enclosed brief questionnaire by Wednesday, September 8 . All responses will remain anonymous.

WHAT YOU COULD WIN-The first 100 households to return their questionnaires will receive a small prize. Plus, EVERY completed questionnaire will be placed in a drawing to receive one of several larger prizes!

ABOUT OPERATION ENERGY-The Operation Energy campaign started in September 1998 as a way to save energy dollars in family housing. Residents' suggestions were used to design and carry out the campaign. Residents were asked to take certain actions in their homes for wise energy. use -- such as controlling temperature and lighting; using washers, dryers, and dishwashers efficiently; and replacing furnace filters.

To determine energy savings, the amount of money each housing community spent on energy was compared with the previous year's spending. The progress made by each community was displayed periodically throughout the campaign.

HOW YOUR INFORMATION WILL BE USED-Pacific Northwest National Laboratory is conducting this survey as a service to Fort Lewis. We will summarize what you tell us in a report to Public Works and Housing officials. They will use the information to continue to find effective ways to help residents use energy efficiently.

REMEMBER--Please mail the completed questionnaire back to me in the enclosed pre-addressed envelope by Wednesday, September 8 . No postage is required. Or, you can fax it.

If you have any questions, please contact me at the toll-free number or e-mail below.

Sincerely,

Andrea Mchakin

Andrea McMakin

Communication Specialist

Pacific Northwest National Laboratory

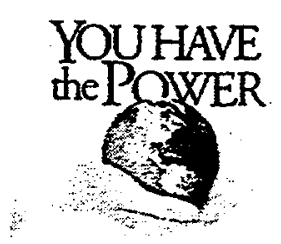

902 Battelle Boulevard $\approx$ P.O. Box 999 a Richland, WA 99352

Telephone 1-888-375-7665 a e-mail andrea.mcmakin@pnlgov $\square$ Fax (509) 372-6328 


\section{Energy Efficiency in Fort Lewis Family Housing}

1. Have you heard about the Operation Energy campaign to use energy more efficiently in post family housing? Yes No (If no, go to Question \#7) Not sure

2. How did you become aware of the Operation Energy campaign? Check all that apply.

My mayor or other mayors

Video on Channel 2. "In Search of the Energy Bandit"

Flier or brochure

Guardian newspaper

Newsletter article from "Under Our Roof" (published by Housing)

My community's newsletter

Other:
Family members, including children

Friends or neighbors

Poster

Display at Kids' Fair or Armed Services day

Reader board

Not sure

3. Have you heard that each housing community that saves energy will receive an incentive award?

Yes No

4. Which community is saving the most energy so far? (Choose one)

Beachwood/Lakewood Davis Hill Greenwood Parkway
Clarkdale

Evergreen

Madigan

5. Here are some things we asked residents to do in Operation Energy. Please check the things that you started doing AFTER Operation Energy began in September 1998.

No change

\section{Heating and Cooling}

Began turning the thermostat down at night before going to bed (or turned it down lower than before)

Began turning the thermostat down when leaving the house for 4 hours or more (or turned it down lower than before)

Asked All Star to repair broken thermostat

Asked All Star to repair caulking or other weatherization materials

Began closing windows and doors when heat was on (or closed them more often than before)

Cleaned or changed furnace filter for the first time (or more often than before)

Reduced or eliminated use of a space heater

\section{Lighting}

Began purchasing new light bulbs at 60 watts or less

Replaced a standard (incandescent) light bulb with a compact fluorescent light bulb

Started turning off outside lights in the daytime (or turned them off more often than before) 


\section{Washing and Drying}

Began using cold water for washing clothes (or used it more often)

Began using the low or cool setting on dryer when possible (or used it more often)

Began running full loads of clothes in washer and dryer

Began cleaning the lint trap in the dryer (or cleaned it more often)

Began running full loads in the dishwasher (or ran them more often)

Began using the air dry setting on the dishwasher (or used it more often)

\section{Refrigerator and Freezer}

Adjusted the refrigerator temperatures to be $37-40$ degrees or the freezer temperature to be $0-5$ degrees

6. What caused you to start doing those things? Check any that apply.

I wanted the incentive award for my community

All the housing communities on post were being compared, and I wanted my community to excel

I wanted more comfortable temperature conditions in my home

I was reminded whenever I saw or heard something about Operation Energy

My family, friends, or neighbors were talking about it

The video (TV) demonstrated how to do things

It's the right thing to do

I want to set a good example for my kids

Other:

7. Is there anything that makes it impractical or difficult for you to save energy? Check any that apply.

My house wastes energy because of the way it is constructed, or because of its age

I have asked to have things repaired that could save energy, but it hasn't happened

The Army does not allow us to do some things that will make the house more energy-efficient

We don't have a cool or air dry setting on our washer/dishwasher/dryer

The kids leave the doors and windows open

I'm too busy to think about it; other things are more important

As long as I'm not paying for it, it's not a priority for me

I won't be stationed here long enough to make a difference

Other:

8. Which housing community do you belong to? (Choose one)

Beachwood/Lakewood

Davis Hill

Greenwood

Parkway

$$
\text { Broadmoor Clarkdale }
$$
Eagle View

Old/New Hillside

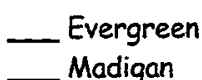

9. How long have you lived there?

3 months or less 4-6 months

7 months to 1 year More than a year

10. In your opinion, what will it take to motivate residents to keep using energy wisely?

THANK YOU!

Please return this survey in the enclosed, postage-paid envelope or for to (509) 372-6328.

Questions? Call Andrea McMakin toll-free at 1-800-375-7665, press "4." 
Note: The questions here are the same as those in the survey questionnaire. However, because of sub-numbering in the survey database, some of the question numbers here are different than those on the original questionnaire:

\begin{tabular}{|c|c|}
\hline $\begin{array}{c}\text { Question } \\
\text { number here }\end{array}$ & $\begin{array}{c}\text { Corresponds with } \\
\text { this question } \\
\text { number in the } \\
\text { survey } \\
\text { questionnaire }\end{array}$ \\
\hline 6 & 5 \\
\hline 7 & 5 \\
\hline 8 & 5 \\
\hline 9 & 6 \\
\hline 10 & 7 \\
\hline 11 & 8 \\
\hline 12 & 9 \\
\hline 13 & 10 \\
\hline
\end{tabular}

1. Have you heard about the Operation Energy campaign to use energy more efficiently in post family housing?

$$
\begin{aligned}
& \text { 整 A. Yes }
\end{aligned}
$$

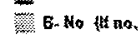

$$
\begin{aligned}
& \text { C. Hot sure }
\end{aligned}
$$

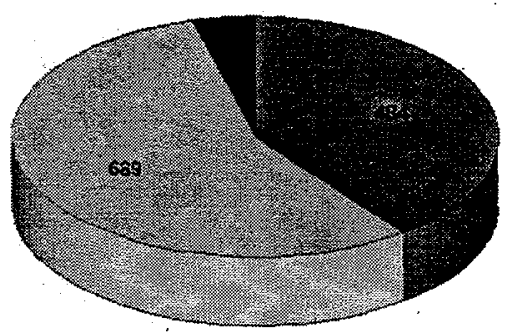

No Filter

Mumber of terpones: 1226

1. Have you heard about the Operation Energy campaign to use energy more efficiently in post family housing?

No Filter

Choice Texts
A- Yes
B- No (If no, go to Question \#7)
C- Not sure
Total

\begin{tabular}{lr} 
Responses \\
Count & \multicolumn{2}{c}{ Percent } \\
484 & 39.48 \\
689 & 56.2 \\
53 & 4.32 \\
1226 & 100
\end{tabular}

Response

Answered question

Respondents (unfiltered)

Count Percent

$1226 \quad 99.59$


Did not answer question

2. How did you become aware of the Operation Energy campaign?
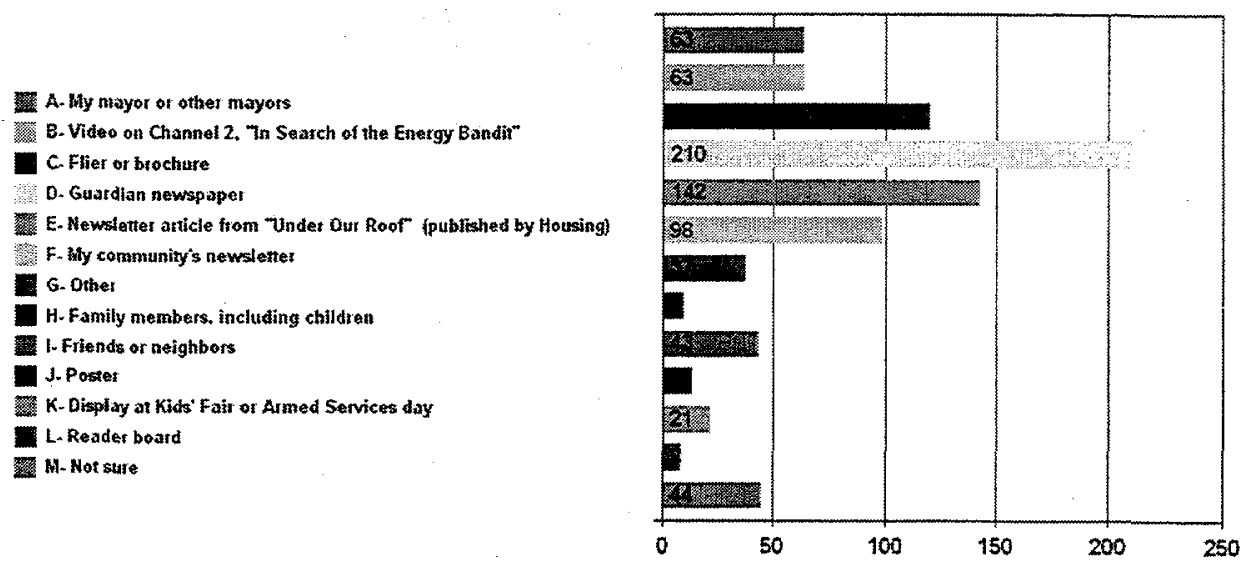

No Filter

Number of responses: 529

2. How did you become aware of the Operation Energy campaign?

No Filter

Choice Texts

A- My mayor or other mayors

B- Video on Channel 2, "In Search of the Energy Bandit"

C- Flier or brochure

D- Guardian newspaper

E- Newsletter article from "Under Our Roof" (published by Housing)

Responses

Count

Percent

$\begin{array}{rr}63 & 7.23 \\ 63 & 7.23 \\ 120 & 13.78 \\ 210 & 24.11 \\ 142 & 16.3\end{array}$

F-My community's newsletter

$98 \quad 11.25$

G- Other

37

4.25

$\mathrm{H}$ - Family members, including children

$9 \quad 1.03$

1- Friends or neighbors

43

4.94

J-Poster

$13 \quad 1.49$

K- Display at Kids' Fair or Armed Services day

21

2.41

L- Reader board

$8 \quad 0.92$

M- Not sure

$44 \quad 5.05$

Total

871

100

Average \# choices chosen per response

1.65

Response

Answered question

Respondents (unfiltered)

Did not answer question

Count

Percent

$529 \quad 42.97$

$702 \quad 57.03$

Answer unavailable

Total

1231

100 
2. How did you become aware of the Operation Energy campaign?

No Filter

G- Other

Post FT. LW. MO

All State employee

Community meeting

This flyer

Children's school

I have been \& spouse since 1978.

someone came to our G.S. leaders meeting.

This letter

Letter from Pacific Northwest National Laboratory

My command

Housing counselor

Received this same paper in mail; accidentally took it to the recycling with the newspapers.

This letter that came in the mail.

Thermostat instruction booklet

Advisory Board Meeting

Ranger

This survey

Your survey

3. Have you heard that each housing community that saves energy will receive an incentive award?

露 A-Yes

Na.No

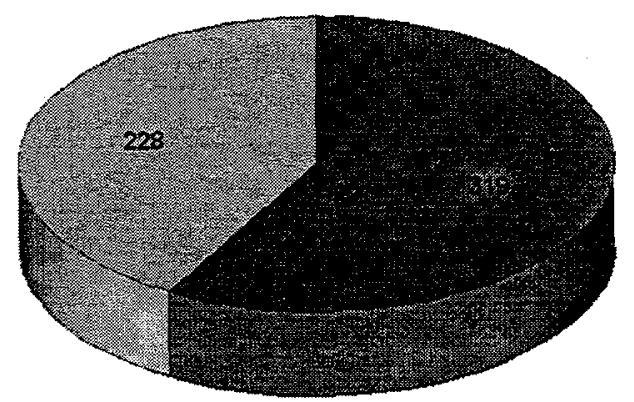

No Filter
Number of responses: 547

3. Have you heard that each housing community that saves energy will receive an incentive award?

No Filter

Choice Texts

A-Yes

Responses

Count Percent

$319 \quad 58.32$ 
B- No

Response

Respondents (unfiltered)

Answered question

Count

Percent

Did not answer question

$547 \quad 44.44$

Answer unavailable

$684 \quad 55.56$

4. Which community is saving the most energy so far?
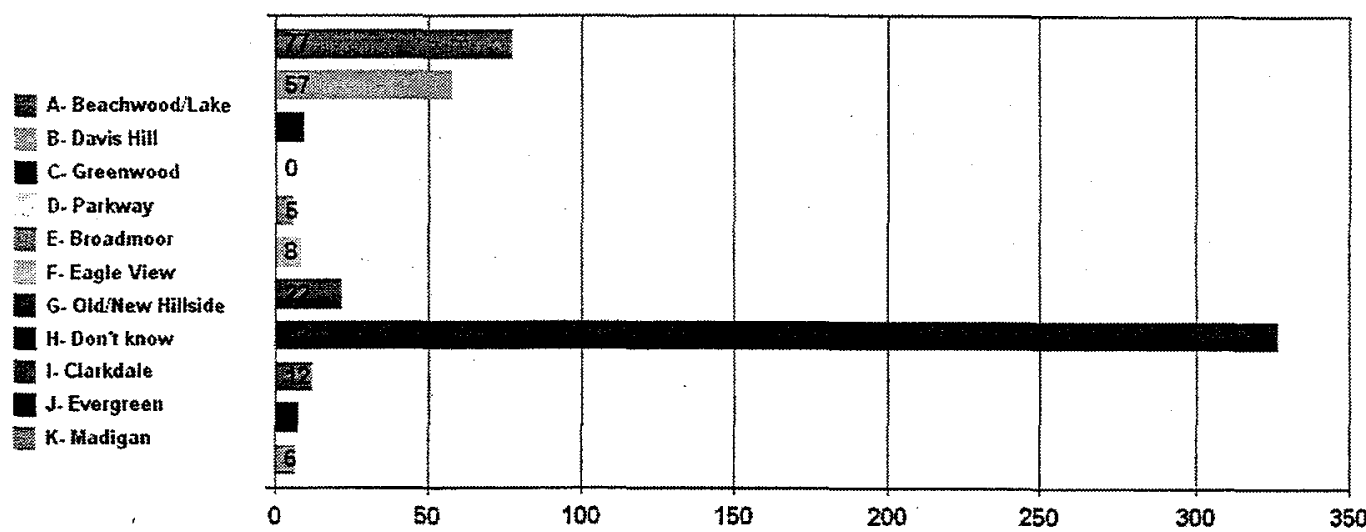

No Filter

Number of responses: 529

4. Which community is saving the most energy so far? No Filter

\section{Choice Texts}

A- Beachwood/Lakewood

B- Davis Hill

C- Greenwood

D- Parkway

E- Broadmoor

F-Eagle View

G-Old/New Hillside

$\mathrm{H}$ - Don't know

1- Clarkdale

J-Evergreen

K-Madigan

Total

\begin{tabular}{rrr} 
Responses & \\
Count & \multicolumn{2}{c}{ Percent } \\
77 & 14.56 \\
57 & 10.78 \\
9 & 1.7 \\
0 & 0 \\
5 & 0.95 \\
8 & 1.51 \\
22 & 4.16 \\
326 & 61.63 \\
12 & 2.27 \\
7 & 1.32 \\
6 & 1.13 \\
529 & 100
\end{tabular}

Response

Answered question

Respondents (unfiltered)

Did not answer question

Count

Percent

529

702
42.97

57.03 
Answer unavailable AFTER Operation Energy began in September 1998.

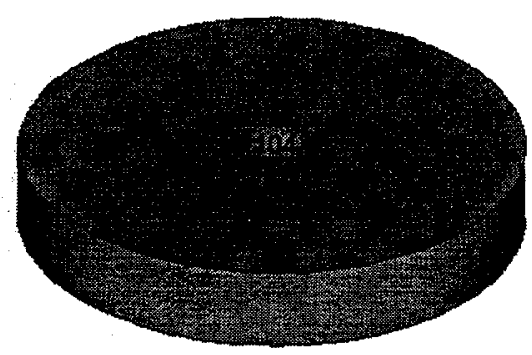

No Filter

Number of responses: 104

5. Here are some things we asked residents to do in Operation Energy. Please check the things that you started doing AFTER Operation Energy began in September 1998.

No Filter

Choice Texts

A- No change

Total

Responses
Count
$\begin{array}{rr}104 & \text { Percent } \\ 104 & 100 \\ & 100\end{array}$

Response

Respondents (unfiltered)

Answered question

Count

Percent

Did not answer question

104

1127

8.45

Answer unavailable

0

91.55

Total

1231

100

6. Heating and Cooling

A. Eegon turniag the thermostat down at night befose going to bed for turned it down tower than

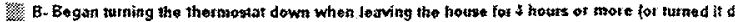
C. Askod All Star to tapait bioken thermostat

D. Asked All Stus to reposit casslking of other we stherization materiats

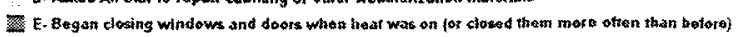

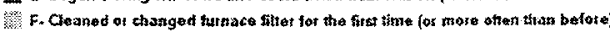

- G-Reduced ol otiminated use of a space hestel

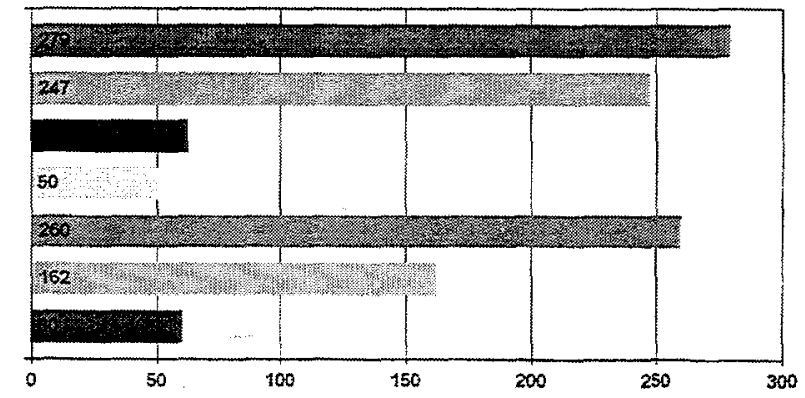

Mo Fither

C.8

Nomber of responses: 404 
Heating and Cooling

No Filter

\section{Choice Texts}

A- Began turning the thermostat down at night before going to bed (or turned it down lower than before)

B- Began turning the thermostat down when leaving the house for 4 hours or more (or turned it down lower than before)

C- Asked All Star to repair broken thermostat

D- Asked All Star to repair caulking or other weatherization materials

E- Began closing windows and doors when heat was on (or closed them more often than before)

F- Cleaned or changed furnace filter for the first time (or more often than before)

G-Reduced or eliminated use of a space heater

Total

Responses

Count

Percent

$279 \quad 24.91$

$247 \quad 22.05$

$62 \quad 5.54$

$50 \quad 4.46$

Average \# choices chosen per response

$260 \quad 23.21$

$162 \quad 14.46$

$60 \quad 5.36$

$1120 \quad 100$

2.77

Respondents (unfiltered)

Response

Answered question

Count Percent

Did not answer question

404

32.82

Answer unavailable

827

0

1231

67.18

Total

100

7. Lighting

A. Eegan purchasing new ligh bulls at 60 wats of less

B. Replaced a standard (incandescem) hight bulb with a compact fluorescent light bub

C. Started tuning off outside lights in the daytime for rumed them off more onen than before)

D- Began using cold woter for wasking clotties for used in more often)

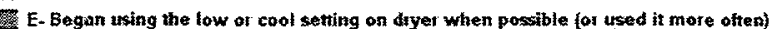

WX. Fegan sunning full loads of clothes in wasker and dryer

T. Began cleaning the lint trap.in the diyer fol cleaned it more often

H. Began zunning full loads in the dishwashe (or tan them more often]

Wegan using the air diy seating on the disliwasher for tesed it more often)

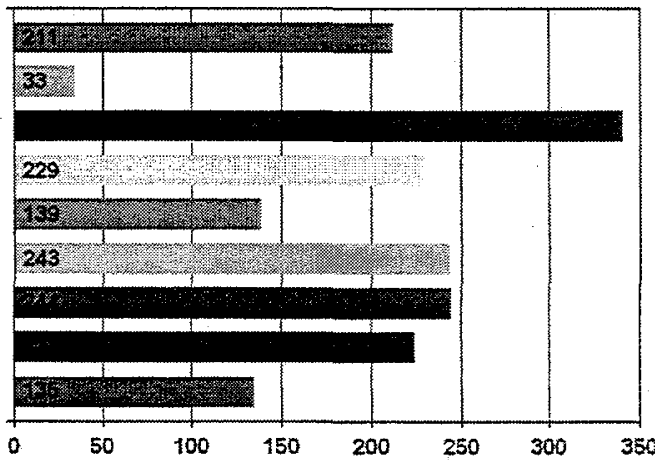

No Filter
Number of responses: 412

7. Lighting

No Filter 
Choice Texts

A-Began purchasing new light bulbs at 60 watts or less

B- Replaced a standard (incandescent) light bulb with a compact fluorescent light bulb

C- Started turning off outside lights in the daytime (or turned them off more often than before)

D- Began using cold water for washing clothes (or used it more often)

E- Began using the low or cool setting on dryer when possible (or used it more often)

F- Began running full loads of clothes in washer and dryer

G- Began cleaning the lint trap in the dryer (or cleaned it more often)

$\mathrm{H}$ - Began running full loads in the dishwasher (or ran them more often)

1- Began using the air dry setting on the dishwasher (or used it more often)

Total

Average \# choices chosen per response

Response

Answered question

Did not answer question

Answer unavailable

Total

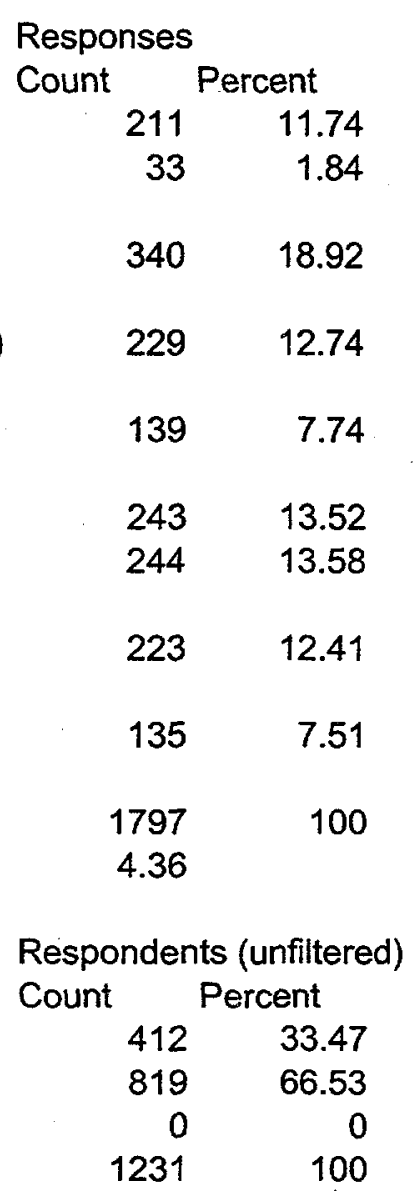

8. Rofigerater and Froezor

A. Adjurred:

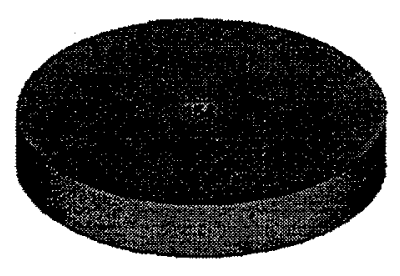

No Fllor
Number of tospomese 164

8. Refrigerator and Freezer

No Filter

Choice Texts

A- Adjusted the refrigerator temperatures to be 37-40 degrees or the freezer temperature to be $0-5$ degrees

Total

\section{Responses}

Count Percent

164 . 100

$164 \quad 100$ 
Response

Answered question

Did not answer question

Answer unavailable

Total
Respondents (unfiltered)

Count

Percent

164

1067

13.32

0

1231

9. What caused you to start doing those things?

A. I wamed the incentive award for my commanity

W. All the housing communitios on post ware being compared, and I wanted my

C. 1 wanted mote comfottable temperature conditions in my home

D. I was reminded whenever 1 sinw or heard something about Operation Energy

F. Waty family, triends, or netghbors were ralking about it

F. The video (T) denunstrated hose to do things

G. It s the right thing to do

H-I want to set a good example for my kids

W. Other:

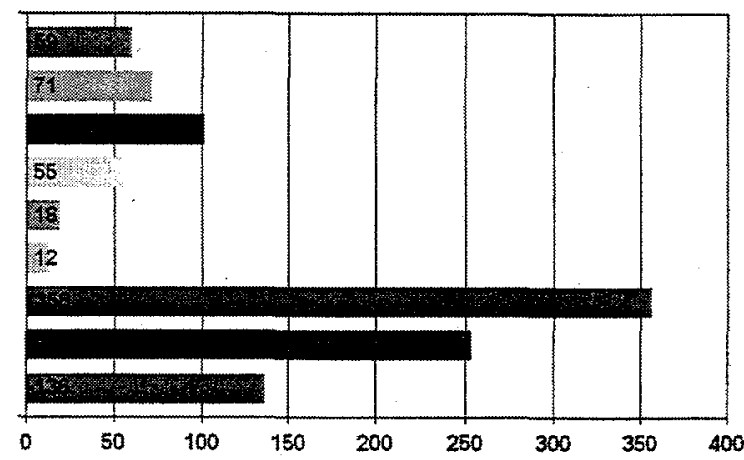

Mo Fitres

Number of cesponses: 472

9. What caused you to start doing those things?

No Filter

Choice Texts

A- I wanted the incentive award for my community

B-All the housing communities on post were being compared, and I wanted my community to excel

C- I wanted more comfortable temperature conditions in my home

D- I was reminded whenever I saw or heard something about

Operation Energy

E- My family, friends, or neighbors were talking about it

F- The video (TV) demonstrated how to do things

G- It's the right thing to do

$\mathrm{H}$ - I want to set a good example for my kids

1- Other:

Total

Average \# choices chosen per response

\begin{tabular}{rr} 
Responses & \\
Count & \multicolumn{2}{c}{ Percent } \\
59 & 5.56 \\
71 & 6.69 \\
& \\
101 & 9.52 \\
55 & 5.18 \\
& \\
18 & 1.7 \\
12 & 1.13 \\
356 & 33.55 \\
253 & 23.85 \\
136 & 12.82 \\
1061 & 100 \\
2.25 &
\end{tabular}

\section{Response}

Answered question

Respondents (unfiltered)

Did not answer question

Count

Percent

$472 \quad 38.34$

$759 \quad 61.66$

Answer unavailable

0

1231

Total

100 


\section{Coding categories for Q9, "What caused you to start doing those things?" ("Other")}

(Numbers total more than $100 \%$ because some responses were coded under more than one category.)
A. Kids influenced me/did it for my kids $(4 \%, \mathrm{n}=6)$
B. Fear of being charged for utilities/privilege living on post $(6 \%, n=8)$
C. Habit/upbringing/always did $(59 \%, n=79)$
D. Right thing to do/wrong to waste $(19 \%, \mathrm{n}=25)$
E. Protect our environment/future $(7 \%, \mathrm{n}=9)$
F. Was told to do it/learned what to do $(1 \%, \mathrm{n}=2)$
G. Prepare for when I live off post $(9 \%, \mathrm{n}=12)$

\section{What caused you to start doing those things?} No Filter

A

A

A

A

B

B

B

B

B

B

B

C

C

C

C

C

C

C

c

c

C

C

C

I-Other:

1 My children brought things from school and wanted to try them out.

13 I want my kids to learn to save energy for my own home in the future.

43 Energy saved today protects children's tomorrow

77 My kids give me suggestions that they learn at school, such as washing your car in the grass - it also waters your lawn at the same time.

$2 \mathrm{I}$ am also concerned that post housing might go to a charge basis, such as having electric bills.

34 I appreciate the fact that $\mathrm{i}$ don't pay the bill. I want to keep it that way.

59 Because it is not coming from my pocket. If I don't have to pay my electricity I am going to do what I can to keep it low, so I do not have to pay it in the future.

69 Rumors of charging me for my electric bill if a reduction in cost wasn't seen.

70 I enjoy the benefits of on-post housing and would like them to continue for others. 119 Keep from paying utilities on post.

127 I don't want to have to start paying for it while I'm in government housing.

G

123 Habit from paying utilities...potential utilities when move.

3 I was already doing most of these things for years.

$4 \mathrm{It}$ is normal for me to conserve energy from I was a child.

5 I did not change anything because I am conservative to start with.

7 I have been doing my best to preserve energy.

10 it is just an everyday thing we always do.

11 Have always done things.

14 Always have tried to save energy. Energy $=\$$

16 I have always been saving energy

17 Just the way I was brought up by parents

19 It just makes sense. We've always done things that way.

23 I was already doing most of these things already.

27 I have already been doing all of these things, so I just continue to do the same.

28 Just good habits to have no matter where you live! 
29 Have always done them for conservation reasons.

30 I was taught in California to do most of this as a child.

35 It was the way I was raised

37 Always been taught this way

40 It is the way I was raised

41 I'm just a conservative type of person

42 I have always done it. (less work i have to do every day.)

44 l've always conserved energy

45 I have always done all the things to save energy

46 Always have

47 I've always been energy conservative. I use energy just as if I were paying for it as a civilian.

49 I always do these things

50 Raised to be a responsible adult (home training)

53 I was raised to be energy efficient

54 I have always done so and more.

55 No matter where we live, I try to conserve energy

57 I have always done this

61 I have always been cautious when it comes to electricity

62 l've always conserved energy whether it was there or not!

63 Was raised to conserve energy

65 l've always budgeted, why stop now!

66 I have always saved energy

67 Do it all the time

72 I have always been aware of my usage. You don't always live in housing. It's best to keep the same habits no matter where you live.

73 I have a always been energy conscious.

74 We always try to conserve energy.

75 We have always done that before.

76 I am from CA, it's necessary to conserve there. So I got used to it.

79 Things that I always have done.

80 Things I have always do

81 I have always done these things.

82 Many of the changes listed were thing we had always done to save energy.

83 Always did it because I was raised this way.

$85 \mathrm{It}$ is all out of habit.

86 We just moved in. I've always tried to be energy efficient even before moving into quarters.

87 I have always done these things.

88 That is how my parents taught me.

90 We have always practiced these - We owned a home.

91 Did it anyway.

92 I was taught to do these things by my parents.

93 I'm German and we know how to save energy, because we pay for everything.

94 Have always done these things.

96 The normal that I always do.

97 I was raised to save energy efficiently.

98 Already was conserving

99 Our family has always tried to be energy efficient.

101 We always did it because we use to pay the energy bills. We know how high they can be.

102 I did most of them before the campaign.

104 Habit

106 I've always been pretty energy wise. Its the way my parents brought me up.

107 I've always done most of these things on my own where ever l've lived.

108 I've always been aware of things I should do to save energy. 
111 I have always saved energy before this campaign.

112 Habit - already doing all of the above.

114 Common sense.

116 I've always done it.

118 I already do most of these things.

1201 always have been energy conscious.

125 I already do most of the things listed above.

126 Started doing this as a child. Just natural to do.

130 We always do these things.

131 I've just always done these things.

133 Always do it.

134 This is a normal thing for us.

109 l've always practiced all these energy saving techniques to reduce wastefulness and teach my children conservation.

78 I believe in avoiding energy waste and want to save tax payer dollars. It's privilege to live here.

6 Just because we live in housing should not mean that everything is free.

9 I do not like wasting energy, especially if I can help out something somewhere.

12 I hate to waste energy.

20 I want it to be just like IF I pay for electricity bills myself.

21 It's what l'd do if I didn't live on post.

22 It's a good idea to stay in a conservation routine. Just because we don't send off a check to the utility company, someone pays.

25 I live by these rules anyway. I treat the military quarters the same way as if it was my own house. I am an energy efficient person, and I don't like things wasted.

31 Thought all of us have to do our part.

32 Save money \& energy on \& off post.

64 Too many abuse government provision

68 It saves energy and money

71 it costs the government (tax payers) good money.

84 Team work is all that matters, for out military family to do these things to save us bucks, or for Uncle Sam to pay our hubby's job or give them a pay raise.

89 I feel I conserve as much as possible.

95 Just a good thing to do.

103 I wanted to do it for myself. I would do it if I had to pay or not for it.

110 Tax dollars pay for the energy my family uses so it should be used sparingly.

117 I prevent fraud waste and abuse of government property

124 Want to conserve.

128 I wanted to support this program.

129 Because it's common sense to be energy efficient.

132 Save government money and save energy.

33 Saving energy helps make a better environment for my kids later!

38 Wasting energy is hard on the environment and hard on the U.S. checkbook

8 I want fort Lewis to become more environmentally "up to date" i.e., : curbside recycling

36 It costs less \& is good for the environment

48 To stop burning fossil fuels

51 I care about the future

$56 \mathrm{It}$ is better for our environment.

60 I want energy to be available/affordable when my children are grown.

115 Better for the environment.

24 AFN brainwashing

121 I didn't know every tip to conserve energy before. The newsletter explained.

122 When I purchase my own home, it will help in conserving energy so I practice some habits from childhood too.

15 When I move off post, I will be in the habit so I don't have a high bill. 
18 Do it right so when we move off post we'll be used to it.

26 We do things for habit, so when we live off post we will still save energy and money.

39 I want to start good habits now prior to leaving the military

52 Get used to it, so when we move into our own home.

58 To get better prepared for when I have to pay the bills out of my pockets

100 I want to start good habits now before I purchase my own home.

105 If I get out of the Army, I need to remember what it's like to pay for utilities.

113 We want to be ready for when we live off base.

135 To keep in practice for when I live off post.

10. Is there anything that makes it impractical or difficult for you to save

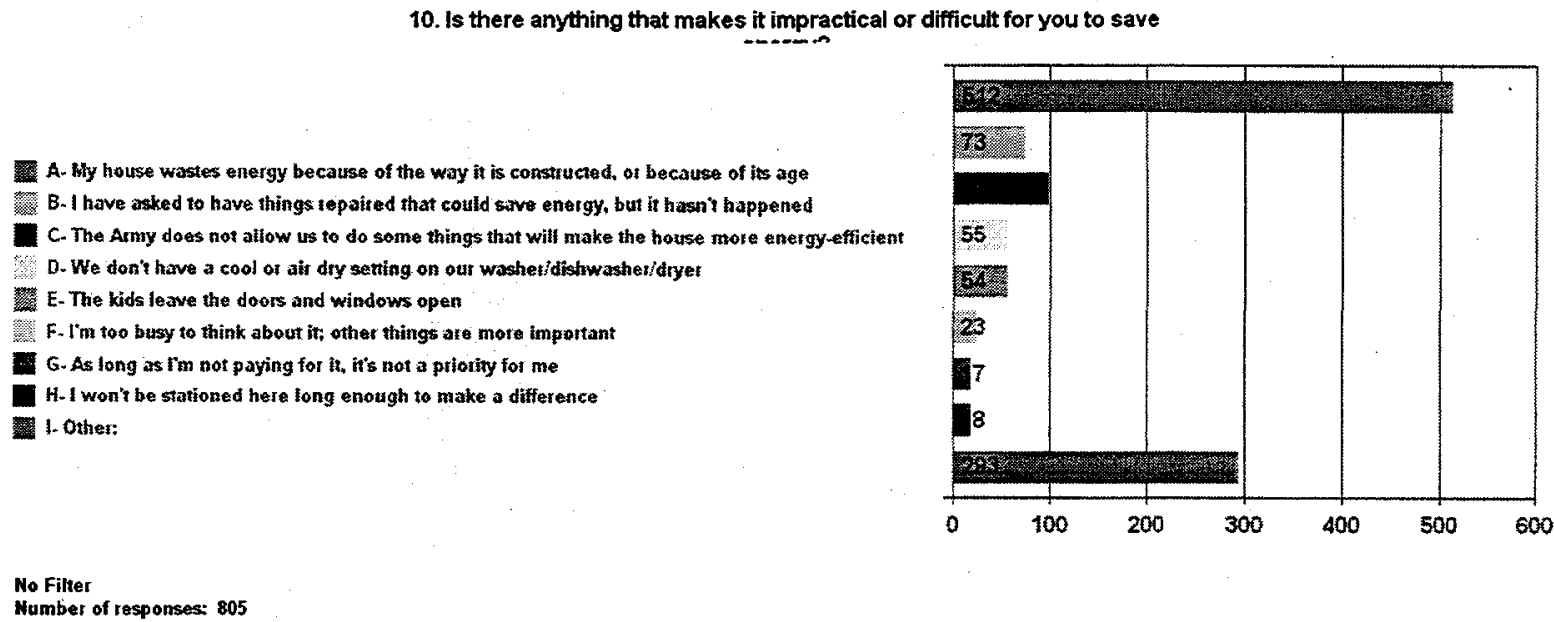

10. Is there anything that makes it impractical or difficult for you to save energy?

No Filter

Choice Texts

Responses

A- My house wastes energy because of the way it is constructed, or because of its age

B-I have asked to have things repaired that could save energy, but it hasn't happened

C- The Army does not allow us to do some things that will make the house more energy-efficient

D- We don't have a cool or air dry setting on our

washer/dishwasher/dryer

Count

Percent

$512 \quad 44.83$

$\mathrm{E}$ - The kids leave the doors and windows open

F- I'm too busy to think about it; other things are more important

73

G- As long as I'm not paying for it, it's not a priority for me

$\begin{array}{rr}73 & 6.39 \\ 97 & 8.49 \\ 55 & 4.82 \\ & \\ 54 & 4.73 \\ 23 & 2.01 \\ 17 & 1.49 \\ 18 & 1.58 \\ 293 & 25.66 \\ 1142 & 100\end{array}$

I- Other:

1.42

Average \# choices chosen per response

Respondents (unfiltered)

Response

Count Percent

Answered question

$805 \quad 65.39$

Did not answer question

$426 \quad 34.61$ 
Answer unavailable

Total

Coding categories and number of responses for $Q .10$, "Is there anything that made it impractical or difficult for you to save energy? ("Other")

(Numbers total more than $100 \%$ because some responses were coded under more than one category.)

\section{A. Housing}

A.1 Energy-inefficient homes, appliances, etc. $(44 \%, n=127)$

A. 2 Problems with repairs/maintenance $(4 \%, \mathrm{n}=11)$

A.3 Not enough base resources to fix our own homes $(1 \%, \mathrm{n}=3)$

B. Others waste our home's energy, including family members $(2 \%, n=3)$

C. Weather $(.3 \%, \mathrm{n}=1)$

D. Don't want to be uncomfortable/unhealthy/have a bad lawn $(3 \%, \mathrm{n}=8)$

E. Safety $(2 \%, n=6)$

F. Forget/not a habit/don't think about it/not aware of what to do/don't care $(3 \%, \mathrm{n}=10)$

G. Not sure/don't know $(2 \%, \mathrm{n}=5)$

H. No/already saving energy $(38 \%, n=110)$

I. Other, including giving suggestions for saving energy $(5 \%, \mathrm{n}=15)$

10. Is there anything that makes it impractical or difficult for you to save energy?

No Filter

I- Other:

A.1 A.2 24 Windows have drafts and maintenance is taking a long time to put new windows in.

A.1 A.2 148 I live in old hillside where the wind is cold comes in under all 3 of my doors and all of my windows. I have had then out to replace bottom of door, no help. Why are we punished because no one wants to make repairs on up keep in our housing area.

A.1 A.2 152 Windows are so old, the air blows through. I asked for a storm door in Oct 98 , never got one.

A.1 A.2 164 Windows old. Seals between glass broken. All Star will not fix them; turned down work order.

A.1 A.2 177 My clothes line was removed in March for siding work. Have called several times to request replacement as I dry my clothes outside in the summer.

A.1 A.2 197 Windows are paper thin, it takes All Star 5 days to fix leaking faucets. 
A.1 A.2 241 Windows and frames are falling apart - All Star will not fix. No cost effective until windows and siding is renewed. There is no way you can save energy in our housing.

A.1 A.3 227 Wasted heat goes through doors with no seal and cold comes in through the windows. Help the residents get fluorescent bulbs instead of incandescent for outdoor/indoor light fixtures.

A.1 D 119 Gas appliances would save a lot, but are not available. Even following the water schedule during summer is not enough for the grass and plants to live.

A.1 E 243 I was told to leave every window cracked open in the winter with the heat on because my windows are old they sweat and cause bad mold problems. Not to mention if there was a fire, no one but small children can fit through the windows.

1 Our house is old even though it has recently received new siding and doors, there are serious drafts by the doors.

A.1

A.1

A.1

A.1

A.1

A.1

A.1

A.1

A.1

A.1

A.1

A.1

A.1

A.1

A.1

5 no double glass windows

6 The windows need to be replaced

14 House seems to be really cold, may be because bare floors and the type of windows.

17 Windows are too old and leak air in and out.

23 Water consistently leaks in both bathrooms, and toilets too.

$28 \mathrm{My}$ radiator does not turn off in summer, making fans necessary, even on cooler days.

30 the windows are terrible.

31 Large single pane windows.

32 The house is old, but I am sure new siding helps.

36 No carpeting makes the houses colder \& this makes for more heat needed.

40 We had terrible drafts by the windows and doors, but since they have replaced those in Clarkdale in the past 3 months, there no more drafts.

43 Tile floors are so cold in winter time.

45 The dishwasher is so small that it has to be run every day (I do thank God I HAVE a dishwasher)

46 Doors and windows leak air like crazy

50 All the heat goes upstairs and in the kitchen and doesn't stay in living room very annoying!

A.1

A.1

A.1

A.1

A.1

A.1

A.1

A.1

A.1

A.1

A.1

A.1

A.1

A.1

51 There is not storm windows or blinds for our house. Having these would help save energy, keeping the heat in better during winter and cool during summer and fall.

52 Windows and doors are drafty, very drafty.

56 Old windows replaced before new siding installed (Davis Hill).

58 The window frames and door frames let cold and hot outside air in

61 A large draft from around windows and doors, and floors are cold.

64 The windows are large and the cold goes right through them. It would be good if they Army made them double pane.

65 Poor insulation around new doors and windows; heat goes out!

67 Need better energy efficient windows

68 The windows need to be double paned and recaulked.

$81 \mathrm{My}$ back door and screen have cracks under them

82 The windows do not seal properly. Radiators are only on \& off, no settings, so it is freezing or a heat wave! Many radiators do not even turn off all year.

84 Carpeting would help to keep it warmer. I can't afford to carpet the house myself right now.

88 Our windows need to be replaced/fixed (too old)

A.1

A.1

91 To heat up the bedroom, the whole house has to get warm. Can't regulate heat individually.

93 All of my windows leak air in and out. We need new windows!!!

94 Need to reconstruct bathroom windows 
A. 1

A. 1

A. 1

A. 1

A. 1

A.1

A.1

A. 1

A.1

A. 1

A.1

A. 1

A.1

A.1

A.1

A.1

A.1

A. 1

A.1

A.1

A.1

A.1

A.1

A.1

A. 1

A.1

A.1

A.1

A.1

A. 1

A. 1

A. 1

A. 1

A. 1

A. 1

A. 1

A. 1

A. 1

A. 1

A. 1

A. 1

A. 1

A. 1
96 Windows

97 Carpet would help save energy providing warmth and less use of heaters.

98 Our windows are letting cold air in. We still have old windows

99 Poorly insulated

100 If they would replace the old windows there wouldn't be so much heat loss!

101 Carpet would help. Can't make FCC more efficient during day care hours.

102 The windows are single pane and are not as efficient as new double or triple pane.

108 New windows would be nicer with insulation and doors

114 During the winter the upstairs is cold unless you let the heater run a long, long time.

116 No carpet - poor window and door caulking

122 I believe that more effort needs to be made to provide better, more efficient housing.

124 We have no dishwasher. Constantly hand-washing dishes with hot water.

$125 \mathrm{I} \mathrm{know}$ that it's in line to get windows and siding. So hop to it and start saving NOW!

126 The windows are too old and the door seals don't work; the house is drafty

127 We don't have energy efficient windows and doors

128 Heat is the problem - it all goes out these old trailer park windows - and drafts come in - the bare floors make it even worse

130 House is very drafty around windows and doors

133 Windows are awful

134 cold comes through the windows

135 The windows and doors are very drafty

137 Dishwasher takes almost 2 hours and does not clean well.

138 The windows in my house leak bad

140 Doors and windows leak air through and around them.

141 Bad insulation in houses.

142 We can not turn off our outside light

144 Air comes in around windows and doors when closed. You have to run the heater constantly in winter time to keep warm.

145 Old energy wasting appliances

147 Old appliances cannot conserve energy.

155 Could use storm windows

169 The house stays very hot, new cool/heat system is needed.

171 Windows could be double-paned during winter to help retain heat.

173 The new doors are less energy efficient than the old wood ones. The cold air comes right through them and the cement floors are too cold all the time and even after I laid carpet wall to wall. It is impossible to save energy in an inefficient home.

176 Doors, windows, dripping faucets, old bathrooms.

178 Our house used gas heat before the renovations. Especially the new doors are a waster, they allow for cold air to seep through. Windows are doubled. These houses were cheaply insulated during renovation.

182 Single-paned windows leak heat and cold.

183 Cold air comes right under our doors and windows.

184 I am disgusted with our brand new doors that were just put in this spring, They do not seal and they gap open a lot at the bottom.

191 Window and doors are very drafty.

192 They have no lights in living room so I have to turn on more lamps to light it up.

193 Heat stays upstairs - poor.

194 Singled paned windows.

195 Single paned windows

196 Windows need replaced badly. 
199 Need new windows; cold air seeps through and it makes it more difficult to even be able to keep the temp down.

201 Basement insulation poor, windows cracked around sides, leaky air.

202 thermostats are impractical as are the vents.

205 The windows and doors could be changed to a more energy efficient type, especially the windows.

207 Cold air comes through all the windows. So I am always turning up the heat.

208 Windows leak air.

209 The windows leak air and the walls are thin.

210 The windows waste a lot of energy, as you can feel the cold air come in. They need to be replaced with energy efficient windows, like Ft. Knox.

212 New windows would help. The ones we have leak.

215 Lighting is a real problem because of wiring or some other reason.

216 Everything is old, out of date, and leaks.

217 The windows are old, don't hold heat, and need to be replaced.

218 All doors let wind in.

219 Houses need a lot of work.

220 The windows are so old they have air leaks and do not shut properly

221 Windows are not double pane.

226 Downstairs living room stays cold because of picture windows.

232 If the dishwasher didn't take one hour to wash the dishes, a lot of energy and water would be saved.

233 Bushes are so high we get no sunlight in windows.

234 Allows for heat to exit house - poor installation.

235 I do what I can to save energy.

236 Carpeting may help to insulate rooms. Floors are always so cold.

239 Windows won't close properly.

242 Large one pane windows

244 it is hard to heat my quarters because of the windows. So much moisture and air comes from around the windows. Installing better insulated windows would help immensely.

247 Put new windows in housing. Curtains move in my house when the wind blows. We see light through our doors when closed.

248 Getting the fireplace cleaned out so we can use it.

251 If only Housing would start changing the windows like they have mentioned earlier. They would have to be double window panel.

252 Heat only has two settings: hot or cold, no in between.

255 The old windows allows a lot of air to come in and go out. But they haven't been replaced.

256 We have single pane windows. If you stand within three feet of them you can feel the cold air from outside.

260 This new siding is not insulated right.

264 Double pane windows would be helpful, brick walls.

265 In the winter, it will be harder because the windows aren't very well sealed. I'm looking for the large rolls of plastic to cover them so heat will stay in and I can still see out.

269 Windows don't seal properly.

280 Windows and doorways are very drafty.

282 Air comes under the windows (the silver part)

$283 \mathrm{Bad}$ windows and doors - extreme energy loss-heating and cooling is a battle we lose.

286 Our floor is over concrete. Always coid downstairs unless heat is cranked. The upstairs rooms don't stay heated the same and our downstairs bedroom no matter how high the heat is on - is very cold.

288 Very old housing. 
290 The house needs more insulation and needs to be weatherized, so in the winter you don't have to have the heat on so high.

12 takes a while to get things fixed.

150 All star did not repair caulking when I asked.

268 It just takes so long to get service.

287 Asked All Star for emergency repairs, they tell me 2-3 days.

146 The substandard furnace filters that Self Help issues. It was a roll of filter material and you had to cut your own.

166 more items at Self Help i.e., weather strip, silicone sealant would make it easy for me to make my quarters more energy efficient.

2 Children in the neighborhood turn on the outside water while we are at work.

26 Hard to get children to turn off lights.

47 Kids and husband leave stereo and lights on

70 Husband and child leave lights on inside house when not in room.

103 My husband leaves lights on

167 I have a lazy husband who doesn't care about conserving energy -- turning off lights when he leaves a room

261 Neighbors use same water outlet outside and leave it on all night and day.

27 Cold summer and spring months.

69 My wife works her tail off and spends plenty of time in the field and deserves to come home to a warm comfortable home with warm showers. They were doing siding work during winter, took the facings off windows, colder than ever, turned thermostat up.

109 I would like to be able to water my grass as needed to have a nice looking yard.

136 I am extremely thrifty with all energy for the exception of the heater. I am always cold and I require a very warm household.

$151 \mathrm{My}$ family practices energy conservation but we have to run the furnace often because these quarters are always freezing cold and we have a small child.

156 Family member with severe medical condition prevents some changes

181 Windows are cracked upstairs due to breathing difficulty.

213 Some medical problems - concerning the heater.

112 I need to leave some lights on at night when my husband's in the field.

180 Break-ins on our street force me and other neighbor to leave on our outside lights nightly.

240 I have to constantly leave a light on because some of the house is just too dark. My child will not go to potty if she is too scared. There is no place in the hallway to plug in a night light.

245 Use porch light for security purposes only at nights and to illuminate the American flag.

289 I have my lights on outside because we have had problems with break-ins and people messing around in the garages and I will not turn them off at night.

22 Sometimes I forget.

33 I have not lived here long enough to be informed or involved.

41 Wasn't aware of PW priorities.

62 Bad habits

105 Forgetful

117 There are times that I do forget, running out the door.

222 Just haven't given it any thought.

237 Haven't gotten around to calling maintenance.

277 I didn't really understand the thermostat, summer fan, or furnace on/off.

285 Why should I save the military money when my husband is gone 80 percent of the time. They do nothing for me. I could care less about helping out in any way that benefits them. 


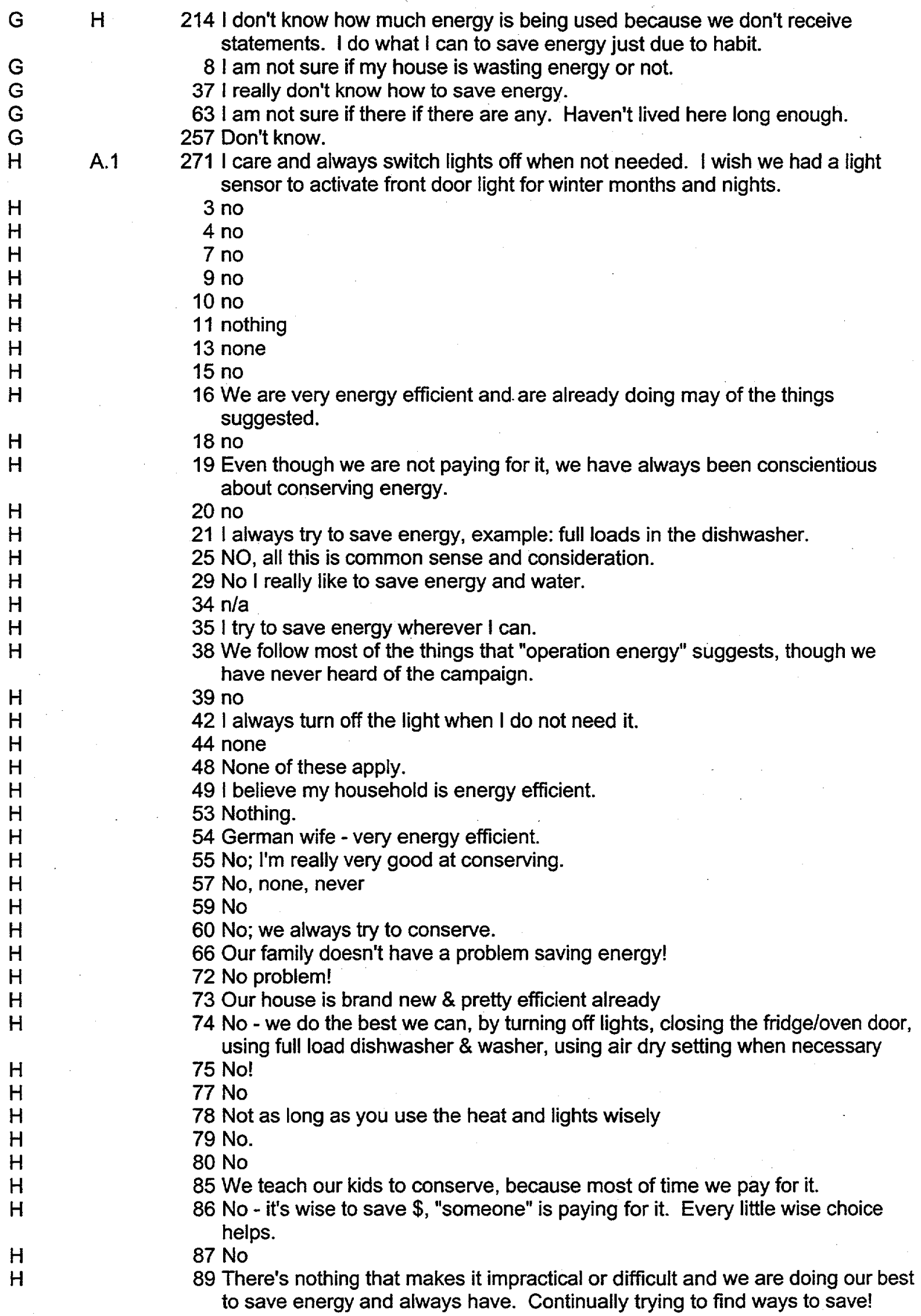

$$
c .21
$$


$\mathrm{H}$
90 None

92 I do try to save energy using sunlight \& turning off lights when not needed, etc...

95 I always do my part to try to save energy and water.

104 We don't have a problem saving energy

110 We are very conservaful by bringing awareness of everything going on.

111 No

113 No

115 We save as much energy as possible

118 We conserve

120 No, I can save energy

121 no

123 I always try to save energy

132 been doing

139 no

143 No

149 None

153 None of the above

154 We're new here, but we do try to conserve energy!

157 I figure as long as I live in it I will do my best to take care of it. It is my home! 158 No - I treat this house as if it were my own. It should be second nature to turn off a light when you leave the room.

159 No

160 No

161 No

162 I think this household does what it can to save energy

$163 \mathrm{No}$

165 We use common sense and have a house in another state

168 There isn't anything impractical or difficult about saving energy.

170 Nothing, we do save energy everywhere we can

172 not at this time.

179 Eagle View was constructed very efficiently. We rarely turn the heat on last winter. (We like it cooler anyway). We need recycling in the neighborhood, newspaper, paper, glasses, cans, plastic. 185 no

186 nothing

187 no

188 no

189 none

190 no

198 None of the above.

200 no

$203 \mathrm{No}$, this is like my first thing to do when I wake up or have my kids ready for school, is to turn off lights outside back/front, inside bathrooms, etx.. My first priority.

204 no

206 no

228 We practice energy saving all the time; some of the things mentioned we do and I wasn't even aware they were considered good.

229 None of the above

231 Nothing is impractical or difficult to save energy.

238 We practice energy conservation.

246 N/A

249 We try to save energy the best we can.

253 There is nothing that makes it difficult.

254 I bought curtains to hold in heat and cool the windows. 
$\mathrm{H}$

H

$\mathrm{H}$

$\mathrm{H}$

$\mathrm{H}$

$\mathrm{H}$

$\mathrm{H}$

$\mathrm{H}$

$\mathrm{H}$

$\mathrm{H}$

$\mathrm{H}$

$\mathrm{H}$

$\mathrm{H}$

$\mathrm{H}$

$\mathrm{H}$

$\mathrm{H}$

$\mathrm{H}$

I

I

I

258 I have always done it.

259 No

262 None

263 Try to maintain habits when not in housing and have to pay for utilities.

266 No, we try to save energy the best we can.

267 None, we save energy as much as we can.

270 I am able to save energy.

272 I don't have a problem trying to save energy in my housing home.

273 We make it a point to save energy.

274 I already try to conserve energy.

275 We try to be very energy efficient.

276 We use the energy we need to live comfortably, as we would in off-post housing, pay for it or not, and we are paying for it.

278 None of the above apply to us. We always take good care of the energy.

279 I try to save the most I can.

281 None

284 We already are an energy efficient family.

291 I don't waste energy

71 You can save by just doing one little thing.

76 Lots of people around water their yard daily.

83 Computer

106 Some rooms have no lights at all. In order to get enough light, adjoining rooms must have lights left on.

107 Need more ideas for our particular housing area that we can do without waiting.

129 moved here in December 98.

131 Work schedule

174 Its' not energy, but we do need curb-side recycling pickup.

175 Just moved here less than a week ago.

211 Leaving in one week.

223 Please send me information.

224 Everyone makes a difference; it's my taxes paying the bill.

225 Housing could install parts in toilet so when flushed you don't waste as much water as you do now.

230 Hot water radiated heat. Not a byproduct of electricity production.

250 Neighbors waste water and light a lot around here.

11. Which housing community do you belong to?

\footnotetext{
A-Beachwoodlake

B. Davis Hill

C. Greenwood

D-Parkway

E-Broadmoor

F. F. Eagle View

G-Old New Hilside

H-Clarkdale

1. Evergieen

1. Hadigan
}

11. Which ho

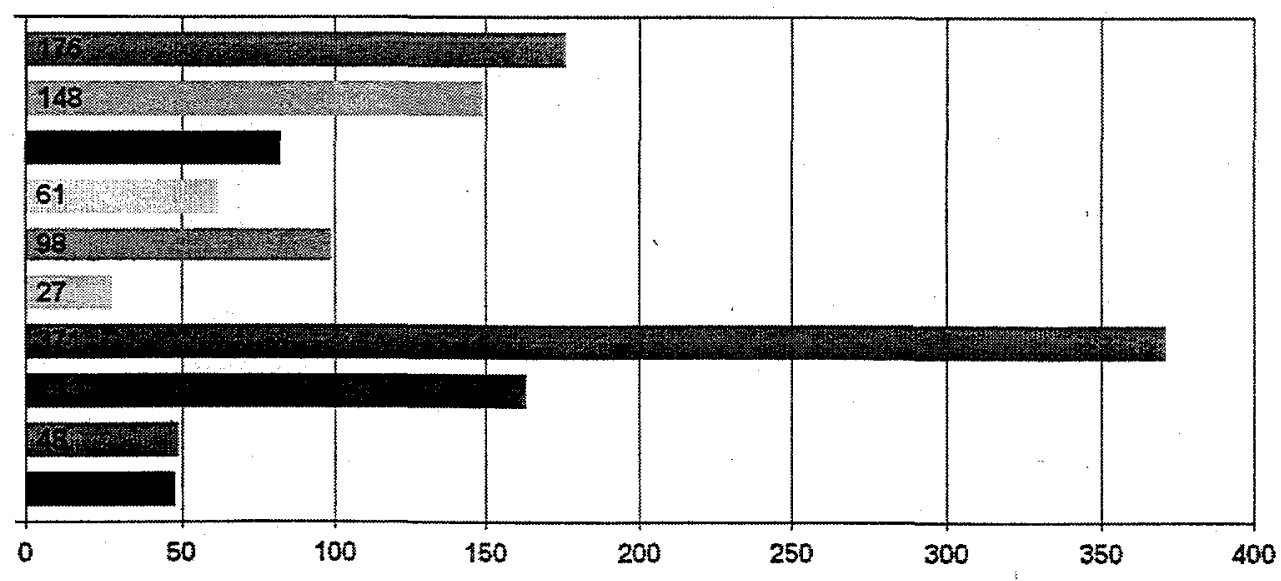

No Filter 
11. Which housing community do you belong to? No Filter

Choice Texts

A- Beachwood/Lakewood

B- Davis Hill

C- Greenwood

D- Parkway

E-Broadmoor

F- Eagle View

G- Old/New Hillside

$\mathrm{H}$ - Clarkdale

I- Evergreen

$\mathrm{J}$ - Madigan

Total

Responses

Count

Percent

$176 \quad 14.43$

$148 \quad 12.13$

$81 \quad 6.64$

$61 \quad 5$

$98 \quad 8.03$

$27 \quad 2.21$

$371 \quad 30.41$

$163 \quad 13.36$

$48 \quad 3.93$

$47 \quad 3.85$

$1220 \quad 100$

Response

Answered question

Did not answer question

Answer unavailable

Respondents (unfiltered)

Count

Percent

1220

99.11

11

0.89

Total

1231

100

12. How long have you lived there?

A. 3 months or less

B. 8.6 months

C.7 months to 1 year

D. Hore than a yeas

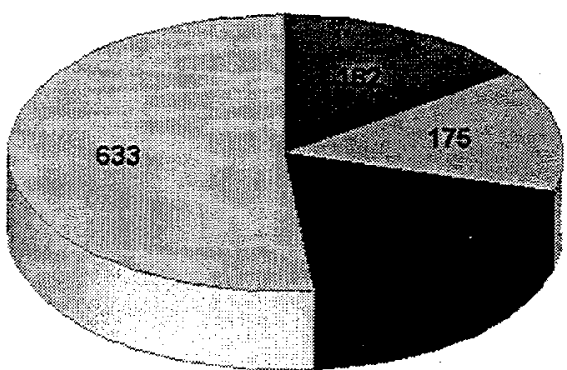

No Filter

Number of responses: 1224

12. How long have you lived there? 
No Filter

Choice Texts

A- 3 months or less

B- 4-6 months

C- 7 months to 1 year

D- More than a year

Total

Responses

Count

Percent

$182 \quad 14.87$

$175 \quad 14.3$

$234 \quad 19.12$

$633 \quad 51.72$

1224

100

Response

Answered question

Respondents (unfiltered)

Did not answer question

Count Percent

Answer unavailable

Total

$1224 \quad 99.43$

$\begin{array}{ll}7 & 0.57\end{array}$

$0 \quad 0$

13. In your opinion, what will it take to motivate residents to keep using energy wisely? No Filter

Response

Answered question

Respondents (unfiltered)

Did not answer question

Count Percent

Answer unavailable

$922 \quad 74.9$

$309 \quad 25.1$

Total

$1231 \quad 100$

Coding categories for Q. 13, "In your opinion, what will it take to motivate residents to keep using energy wisely?"

(Numbers total more than $100 \%$ because some responses were coded under more than one category.)

A. Incentives/rewards $(20 \% ; n=183)$

B. Disincentives/better enforcement/limits/punishment $(5 \% ; n=43)$

B.1 Pay utilities/pay over cap/fine $(17 \% ; n=161)$

B.2 Threaten with payment $(5 \% ; n=48)$

C. Inform/remind/raise awareness/advertise $(24 \% ; n=227)$

C.1 Provide feedback on usage/costs/savings/compare with civilian housing (7\%; $\mathrm{n}=63$ )

C.2 Educate/teach/give classes $(7 \% ; n=60)$

C.3 Social involvement: involve mayors, commanding officers, solder units/ask residents for their ideas/community meetings/community involvement $(2 \% ; n=22)$

D. Make improvements $(.2 \% ; \mathrm{n}=19)$ 
D.1 Better housing/appliances/upgraded housing $(11 \% ; \mathrm{n}=100)$

D. 2 Better pay $(.9 \% ; n=8)$

D.3 Better repairs/maintenance/service $(2 \% ; \mathrm{n}=19)$

D.4 Less intrusion by Housing/Army, feeling like Housing/Army cares, better morale $(2 \% ; n=16)$

E. Monitor or meter use $(2 \% ; n=19)$

F. Appeal to values (environment, taxpayer dollars, waste is wrong, treat like own house, personal decision, next generation, pride, common sense) $(5 \% ; n=49)$

G. Nothing will help; what you're doing now; already doing $(4 \% ; n=40)$

H. Don't know/not sure $(4 \% ; n=37)$

I. Other $(5 \% ; n=42)$

\author{
13. In your opinion, what will it take to motivate residents to keep using \\ energy wisely? \\ No Filter
}
A B $\quad$ C $\quad 9$ Better incentives; penalties; knowledge.
A $\quad$ B
C.1
100 Set up a consistent pattern of awards and punishments. Let individuals know how they are doing compared to average.

$\begin{array}{ll}\text { A } & \text { B } \\ \text { A } & \text { B } \\ \text { A } & \text { B.1 } \\ & \\ \text { A } & \text { B.1 } \\ \text { A } & \text { B.1 }\end{array}$
240 Rewards and penalties
719 Prize for reductions. Threat of eviction for abuse.
B.1 1165 Perks for lowest energy use; payment over certain watts used; pre-set heaters for temperature control.
A $\quad$ B.1
A B.1
A $\quad$ B.2 C 46 More incentives, maybe. Or tell residents they could have to pay their own utilities.
189 Maybe an incentive or if they have to start paying for it or for a portion of it.
467 Incentives are great motivation. I routinely try to save energy - wish l'd known about this earlier! Rewards, prizes and not having to pay utility bills would really motivate. Another motivation would be not paying for utilities up to a certain amount; anything over that is at the service member's expense.
673 The incentive is good. When people have to pay for utilities, guarantee it will go down. Put more articles in the Guardian about saving energy. Maybe some people are not aware of it.
A $\quad$ B.2
A $\quad$ B.2
A $\quad$ B.2

$\begin{array}{ll}A & C \\ A & C \\ A & C \\ A & C\end{array}$
A C
50 Money, threats.
831 Either awards, or the threat to begin charging those who abuse or waste. Why should they ruin it for the conscious energy-efficient-using occupants?
832 Provide individual incentives for best energy usage and post a list of the worst offenders for each community.
74 More incentives, more information, newsletters, etc.
187 Some form of incentive and/or repeated reminders.
248 Just a reward, then reminders.
253 Give some privileges to those housing \#'s who conserve the most energy. Make us more aware of the incentives. I knew nothing about it.
356 Incentive programs, awareness to residents

$$
C .26
$$


A

A

A

A

A

A

A

A

A

A

A

A

D. 1

D. 1

D.1

$\begin{array}{ll}\text { A } & \text { D. } 3 \\ \text { A } & \text { D.3 } \\ \text { A } & \text { D.4 }\end{array}$

A

A

A

A

A

A

A

A

A

A

A

A

A

A
429 A magnet for the fridge or an incentive (blanket) for this warm winter or maybe something environmentally conscious.

573 Make the incentives more tangible and publicize the program more.

683 Incentives and energy conservation awareness.

705 Incentive programs and keeping them informed.

720 Provide community incentives for measured reduction, i.e., sponsor spring/summer block BBQ. Provide occupants with indication of how much electricity/water would have cost off post per month. Numbers mean more than general statements.

231 Rewards for wise energy use; education

432 Incentives and education on how to conserve energy. I have lived here over 18 months and have heard nothing on Operation Energy.

443 More incentives, and maybe if we had a mayor to promote energy awareness

526 Make community awards visible. Beachwood saved the most money - yet our community sign is still broken and the parks need repairs.

516 Incentives, nicer looking places

785 Using money saved for improvements to housing.

916 Incentive program. I would do a lot if someone would fix our playgrounds so we could get out of the house more. The recent energy efficiency report was published in conjunction with the updates on which housing areas were scheduled for what renovations, etc. When you look at which housing areas "saved" how much money and read the renovations schedule, it becomes very clear that there is a direct relationship between new doors and windows plus siding and money saved over the previous year with out. Also supported by which areas were done first vs. last or not al all. When the savings are that ridiculously high vs. $\$ 0$ you can't honestly expect people to believe it is in direct relations to the program of who used which utilities at which wattage, hours, etc. Granted, basic conservation does great wonders especially when each housing unit/area starts on equal footing. But anyone with two eyes and even half of a brain can see the difference between modern windows and doors verses the outdated ones that allow

87 Incentives and better maintenance.

803 Individual incentives and energy efficient repairs.

400 There would need to be more of an incentive and maybe better morale. The military housing can make your pride in living here quite low.

860 Reward them with money saved. This will require metered homes to track.

239 Rewards and recognition. Unfortunately too many just don't care. We do! Although, I was unaware of this program, we do many of these things aiready.

$254 \mathrm{Be}$ realistic on incentives. The letter I received said the first 100 households to return this survey will receive a small prize. Another portion says this survey response will remain anonymous. How can you do both? I'd really like to know the answer to this question.

723 Setting a reasonable amount of energy to be used. If the household goes under, pay them so much money. If All Star or whoever would turn off all lights inside and outside when they left an empty house, that would save a lot of energy. Lock the doors and people won't get in.

7 incentives

11 Incentive

17 Incentives \& gifts.

29 Awarding the community. A lot of people feel that they do not have to pay for it. I am from $\mathrm{CA}$ and had $\mathrm{H} 2 \mathrm{O}$ shortage. Know how to keep water off too.

34 Good incentives.

42 Give some kind of incentives.

43 Something tangible, like an award or gift certificate. "Money talks."

45 Incentives, programs with rewards visible to all.

59 Perhaps money for the community playground to be improved would be a good incentive for residents.

60 Cashback bonus to individuals. 
A

A

A

A

A

A

A

A

A

A

A

A

A

A

A

A

A

A

A

A

A

A

A

A

A

A

A

A

A

A

A

A

A

A

A

A

A

A

A

A

A

A

A

A

A

A

A

71 Some incentive for using energy wisely.

81 Honestly, I think cash rewards, \$, grocery, certificate would work.

86 Reward area with awards.

91 Incentives like they do for the Guard of month, only for saving energy.

105 Reward those that do save energy by sending a "thank you" or something, or maybe a contest of which housing community can save the most energy.

117 Incentive awards to individuals.

121 Incentives.

122 Incentives

130 By giving out prizes

134 An incentive

137 Give out rewards to the person who saves most energy, example: free pizza or free movie tickets

139 Cash incentive to the family

172 Winning something for community or for area: cookout or party for community that wins or something that people will try to win; free gift for area, etc.

174 Rewards

175 Give an incentive!

202 Bonus incentives to housing occupants.

$224 \$$ - It is all about money!

234 Incentives, prizes, etc...

242 Some kind of incentive program

252 Begin a financial incentive program that would benefit residents.

255 More incentives \& involvement

260 Some kind of incentives.

261 Incentives

263 Money, prizes

264 For the uneducated and non-caring individuals without the macro consciousness of saving energy, one thing will motivate them to save... cash back!

268 Give incentives to residents who conserve.

269 A reward program

275 Rewards, block parties, etc...

287 Keep offering residents incentives

292 Make good on the prizes and incentives. Make the prizes and incentives useful and practical, like something the community needs.

304 Give money as an incentive.

305 To continue to offer incentives or bonuses.

308 Some kind of prize - reward for the community that uses the least energy.

322 I have no other idea, but awards for the residents sounds good.

337 Rewards for those that don't care - maybe they will start to care if they

personally get something out of it.

354 incentives help!

373 Community incentives and block parties.

376 More incentives

378 Some sort of community contest for incentive

379 Monetary incentives.

380 Incentives such as certificates to the BX or Commissary

$396 \$$ money or house with lowest energy output gets put in a drawing for their quarters to be cleared for free when they PCS.

403 Incentives

420 Maybe giving away things.

436 An incentive award should work just fine.

438 Lower energy use could give nicer housing. For example, blinds,

dishwashers, new flooring in kitchen/bath.

448 Awards and incentives 
A

A

A

A

A

A
453 Incentives (discount coupons to PX, maybe lawn care for a month, small incentives like movie tickets, etc...)

454 A way that it will benefit them

473 Incentive plan

481 Some sort of incentive

494 Keep giving incentives

499 Small incentives example: special prizes to the housing area that conserves the most energy out of certain period of time.

521 I believe more incentives will motivate people

525 A cash-back incentive

543 Incentive programs, since no one pays a separate utility bill

549 incentives for neighborhoods that save the most energy.

563 Incentives like you are doing now.

564 An incentive

587 Using awards \& incentives (not necessarily monetary) such as parking spaces at AAFES and Commissary, and discount days at on-post recreational facilities.

592 Bigger incentives.

598 Incentive - a 4-day pass for soldiers from the \#1 neighborhood.

603 Incentive and award

625 Incentives.

627 Incentives.

629 The competition of the community wanting to win the incentive award.

633 Actual cash back to residents as rewards for energy saved.

645 More incentives

653 To show them what the savings would be used for.

654 Surveys, with free gifts for the houses who save more.

656 Awarding prizes.

667 Since we do not pay for the energy, possibly an incentive program.

671 Whichever community saves the most for a month gets their lawn cut for a month.

678 Saving money for better playgrounds for the kids.

679 Money coupons or money certificates.

698 Rewards

709 To see what the money can buy that is not wasted on energy.

716 Have a program that rewards residents for saving energy every quarter. Pick the quarters that use the least energy for each housing area and give them $\$ 250.00$ and a parking spot at the PX and Commissary. Then, once a year, pick the overall best and give them $\$ 500.00$; this would motivate most residents. Doesn't have to be cash; it could be gift certificates (AAFES).

746 Give them more incentive.

753 A reward system and/or recognition.

767 For the housing community that saves energy the most, should have a community housing barbecue party paid for by the housing Army. Give each housing family a button pin for best housing community, so that other housing communities would see it too. It should be a nice, attractive button that would make other housing communities be envious of the button and that they would think and work or strive to acquire or achieve it.

769 Incentives!

774 Maybe if we really SEE a reward.

821 An incentive program.

835 Some type of reward system. Free yard maintenance for one month during summer or money or coupon for PX shopping, free dinner at NCO Club, things like these.

848 Rewards.

859 Money can motivate anybody.

861 Drawings to receive a special gift.

874 Some kind of incentive program that rewards the housing area. 
B

893 More innovative incentives.

917 Keep giving incentives

502 An active campaign that reprimands violators and rewards those that take active measures, cash rewards.

642 Make limits for energy use and fine for going over the limits.

143 Tough rules and the promise to obey, and if not, pay utilities or lose quarters

766 People need to be warned or told about how to save energy or water.

148 Enforcing established regulations, turning off exterior light during daylight, establish a program sending readings of electricity conservation periodically, and reward those who used below-average consumption.

641 To have someone enforce standards, and fix things like playgrounds to make them safe for kids.

649 Notification. First, actual motivation. Ability to get supplies from Self-Help Store caulking, winterizing for windows, etc. Screens that fit window so we can use air from outside instead of fans.

449 Not really sure. I guess a few power outages here and there, with an excuse like, "The housing area is using too much electricity."

28 Punish them for not using it wisely.

64 Penalties for using it unwisely.

78 Come down on people who don't care and waste energy.

99 Be strict about leaving the lights on all day.

131 Tell the company commander that they need to turn off light, water, etc. and embarrass soldier.

155 Be more strict.

208 Start hánding out citations (tickets)

418 Setting limits and enforcing them

451 Make it a law on post or give them a cancel report.

508 Monetary for not doing so penalties.

522 Mandatory regulations along with checking to see the outcome

583 Post notes on doors pertaining to individual wastes.

600 Somehow make up tickets and the money would go back into house. For leaving porch lights on or water on when not supposed to be, and maybe some would get the hint.

614 Make it less of an option, more mandatory. People tend not to do things unless held responsible for their actions.

668 Let them know that if they were off-post and had to pay, they would try to save/use energy wisely.

689 Start regular inspection of quarters.

695 Maintaining energy use and accountability.

732 Need to be stricter, at least on turning off outside light in the daytime

735 Impose penalties where energy is abused or neglected to dissuade attitude of "I'm not paying for it."

770 Enforcing the housing rules more.

771 Enforcing the housing rules more.

797 Let them live off base and have to pay the heating cost.

817 Somebody should send notices to those failing to comply with the program.

839 Crack down on the ones who abuse it.

846 Hold them accountable.

887 Have people do random house checks.

195 Make them pay for it or some kind of reward system for saving energy!

277 Either paying for it themselves or setting up a reward system for saving the most energy each month, quarter, year, etc...

293 Making them pay for usage or incentive programs equivalent to "Best yard spring $99 "$ etc...

694 If they are charged for excessive use, or better yet, if they are rewarded in some way for keeping costs down (i.e., PX or Commissary gift certificates). 


$\begin{array}{ll}\text { B.1 } & \text { A } \\ \text { B.1 } & \text { A } \\ \text { B.1 } & \text { B } \\ \text { B.1 } & \text { C.1 } \\ \text { B.1 } & \text { C. } 2 \\ \text { B.1 } & \text { C.2 } \\ \text { B.1 } & \text { D.1 } \\ \text { B.1 } & \text { E } \\ & \\ \text { B.1 } & \text { E } \\ \text { B.1 } & \text { F } \\ \text { B.1 } & \text { F }\end{array}$

B.1 $F$

B.1 F

B.1

B.1

B.1

B. 1

B.1

B.1

B.1

B.1

B.1

B.1

B.1

B.1

B.1

B.1

B.1

B.1

B.1

B. 1

B. 1

B.1

B. 1

B.1
813 Fines imposed on repeat energy abusers, and rewarding individual households for cutting energy consumption.

909 Only if residents pay for energy costs or provide incentives for individuals or neighborhoods with much publicity and a tangible reward.

250 Bill them for excessive use, or reprimand them in a such way.

145 Make them pay their own bill a month to see how much.

C.1 854 Make them pay for it. Educate. Give them a monthly statement and show them how much it would cost.

534 Charge for excess usage/educate kids to turn lights off, close windows etc... - my daughter likes the chance to remind me that I forgot to turn the lights off etc...

812 Set a realistic limit to energy spent, then bill resident what is left - however, housing should be energy-efficient first.

238 You would have to spend money to save energy - allow limits of use, any amount over - residents would be charged but that means someone would have to read individual meters.

344 Find some way to set a limit on the amount of energy used per household, then have them pay for anything in excess. Surprise neighborhood inspections for energy waste.

10 Probably charge them for it. I always use my energy as if I owned this house.

289 If they actually had to live in an apt. or house and pay for all these utilities on post. "Reality" is a good thing. P.S. We moved on post to save the $\$$, but I am still self conscious about the energy I use, because we have had to pay, and it's a good habit for later to get into.

434 Paying for it, but please don't. Some of us do work hard because that's what it means to be a good citizen.

527 If they had to pay for it, they would think twice about doing what is right. In a way we are paying for it with our taxes!

1 Fine residents that use excessive amounts.

2 Charge those wasteful people for their electricity.

12 Come up with a budget limit of money residents are allowed to use on energy. If they go above it, they have to pay. I guarantee you that a lot of those that waste will be more careful.

13 Have them start paying the bill out of their pockets.

23 Make them pay for it.

27 If we had to pay for it, it would become a priority.

63 Make them pay for it.

66 Have them pay for it.

88 Placing a cap - maximum usage amount, or add a fee once they go over the cap.

89 Tell them they will have to pay for their utilities, it would make them think twice.

92 Make them pay for it, give back VHA, BHA \& make them pay as if they were living off post.

97 Make us pay utilities.

101 Make them pay for it.

102 Make them pay all or a portion of utilities, that they use to realize what the cost is compared to a month that they don't pay.

106 Start charging them for the energy they use and give us at least $1 / 2$ of our BAH. If people have to pay for something, they think a little wiser.

113 Set an amount monthly, and if you go over it, you pay the difference. People would pay attention then.

114 Start making them pay for it.

123 Pay extra for extra use of energy.

127 Make them pay their own bills.

135 Pay fines!

147 Make them pay their own utility bills.

149 Start having residents pay for their use of electric; it's very costly on the 
B. 1

B. 1 .

B. 1

B. 1

B. 1

B. 1

B. 1

B. 1

B.1

B. 1

B. 1

B. 1

B. 1

B. 1

B. 1

B. 1

B. 1

B. 1

B. 1

B.1

B. 1

B. 1

B. 1

B. 1

B. 1

B. 1

B. 1

B. 1

B. 1

B. 1

B. 1

B. 1

B. 1

B. 1

B. 1

B. 1

B.1

economy.

153 By charging them for what was wasted

157 Make them pay for it if they go over an allotted amount.

159 Bill them.

161 Make them pay for their own utilities.

168 Make them pay for it themselves!

171 A deduction from service members' pay to offset the cost

190 Make them pay for it.

196 When we have to pay $\$$ for our use of electric!

198 If they would have to pay for it. It makes me very upset when people leave the sprinkler on all day or don't turn the heater down in winter when they are not at home.

206 Perhaps giving a certain amount of each utility free, but requiring those residents who go over the amount to pay for the extra they use.

219 Bill them for energy usage i.e.., electric, gas, water

221 Fines, i.e.., - for leaving the porch light on maybe after 2 warnings, etc.

222 Make them pay the bill.

229 Having to pay for their own excesses \& wastefulness.

232 Paying for it!!

245 Charge them for what they use.

259 Make them pay.

262 Fines for over use of utilities

270 Make them pay a portion of the bill; this would truly make sense. I believe DoD would save not only that portion but they would see a big reduction in consumption. I'm sure of this. I wish they would try it.

272 A bill for "excess" usage - maybe impractical, but the only real way to make residents care about wasted energy.

301 Charging them! Each family should be allotted a base amount each month for utilities; over that they should pay.

306 Start charging for it!!

309 Having them accountable for excessive usage.

317 Having to pay for it!

319 Make them pay for it!

327 A bill for energy use.

333 Tell them they will have to start paying a portion of the bill over a certain, but understandable amount -- after the home has been made energy efficient.

341 Pay for all/partial usage of water/electricity! If you are an energy efficient household, the costs are minimal (average off-post is less than $\$ 35 /$ month) and it would help stop such irresponsible behavior. If the post is serious about promoting energy efficiency and wants results, the only way to affect post occupants is where they are most aware; their pocketbooks. We have neighbors who water whenever they feel like it, regardless of day, time or weather even rain. Sprinklers are often left on for twentyfour hours. If residents were made aware of their usage on terms of costs, positive results would soon follow. The best way to solve the problem would be to set an average usage for consumption -- for both electricity and water. If a residence's usage is above average, the occupants would pay the difference. Also, a similar program could be started with refuse pick-up to encourage recycling, as many other large cities have implemented.

343 I think if residents had to pay for it they would use it wisely

346 Charge them electricity portion thereof

348 If they had to pay the power bill

359 Make residents pay for the amount over the limit.

360 Give a set limit, then charge (a month)

370 Start charging for electric \& water.

372 Make them start paying for it.

377 Start charging (money)

391 Having the residents pay for the electric bill 
B. 1

B. 1

B. 1

B. 1

B. 1

B.1

B. 1

B. 1

B. 1

B. 1

B. 1

B. 1

B. 1

B.1

B. 1

B. 1

B. 1

B. 1

B. 1

B. 1

B. 1

B.1

B. 1

B. 1

B.1

B. 1

B. 1

B. 1

B. 1

B. 1

B. 1

B.1

B. 1

B.1

B. 1

B. 1

B. 1

B. 1

B.1

398 Make them pay for their own utilities

410 Making them pay for wasted energy.

411 Make them pay the bill.

413 Start charging for a portion over a certain limit

415 If they have to pay for it or realize that not leaving VHA is like applying for it - they would try to conserve more.

425 Even though it would hurt some residents, maybe if we were to actually receive the [bill] and had to pay for the rent, electric etc., that it would make a difference. No, I would not be for that to happen but also feel that

437 Give them partial BAH then pay for elec.

458 Those who waste may have to pay in some way? [Not] If it is not their fault i.e.., the way the home is constructed.

460 Penalties for gas/electric bills

482 Come up with a standard energy usage across the board, and charge for over use. That will give people a hint.

512 Make people have to pay for their electricity

528 If they had to pay for it! I think people waste water (by leaving sprinklers on all night) because they don't pay the water bill.

529 Start charging them for their electric! The cleaning teams that clean quarters when residents move out leave all of the lights on in the house for many days before Housing inspects it.

533 I truly believe that people in housing waste energy because they don't have to pay for it. After a certain amount of energy usage, people should be responsible for paying out of their own pocket - they would change quickly!

535 When it affects their pocket. When they have to pay for their energy.

542 Make them pay for it

547 Establish a mean average and have residents pay for excessive amounts of water, energy and power use.

571 For them to pay for it!

574 If they paid on electric bill.

577 Make resident pay for over used energy than what is allotted.

579 Charge them money for excess usage.

599 Charge them for it.

605 Get a price that residents can't go over or they will have to pay. When they don't have to pay, they don't care.

611 If they go over a certain amount, they should have to pay for it.

619 Residents would think twice about energy conservation if we had to pay for it.

621 Make them responsible for what they use over the normal amount.

622 Charge them for utilities. Or keep track of usage, set a usage cap, and make residents pay for utilities that are over the cap.

628 Make them pay for it.

631 Charge them for anything higher than the overall average energy usage.

650 Charge each resident for utilities.

661 Make them pay for energy.

681 Set a ceiling use; if use over this, start charging for over-usage.

691 Have to pay for utilities.

693 Make them pay for what would be over the average family should use.

706 Start charging residents for energy. Then they would know how much water and electric really costs.

707 Start charging people who fail to be energy sufficient. For example, they leave outside lights on all day/night. They don't care if every light in the house is on because they don't pay the bill.

717 To make them pay for excessive over usage of energy.

718 Make them pay a premium/refundable energy deposit.

722 Fines for leaving lights on when you aren't home. Exception for outside garage/entry light (for security reasons). 
B.1

B. 1

B.1

B. 1

B. 1

B. 1

B. 1

B.1

B. 1

B. 1

B. 1

B. 1

B. 1

B. 1

B. 1

B. 1

B. 1

B.1

B. 1

B. 1

B. 1

B.1

B.1

B. 2

B. 2

B.2 C

B.2 $E \quad$ C.1

B.2 $E$

B.2 I

B. 2

B. 2

B. 2

B. 2

B. 2

B. 2

B. 2

B. 2

B. 2
727 Provide them a bill for energy used. This will indicate to them why it is important to save energy.

728 Give them a warning, then charge them for the wasted energy.

729 Residents not using energy wisely will have to pay a fee if the situation is not resolved. I think that sensor lights would save more energy if placed in strategic places. For example, backdoor (outside lights).

737 If they have to pay for it.

749 If someone uses excessive amounts, make them pay.

761 Make them start paying for it.

777 Fines.

778 Making soldiers pay for utilities.

779 Charge for over using.

780 Make them pay for energy used over a certain set amount.

781 Have a monthly usage allowance based on family size and housing area. Anything over the allowance must be paid for out of the resident's pocket.

789 Make residents pay.

805 Make individuals responsible for excess usage.

807 Start charging for usage.

816 Set an average rate for each housing area and charge individuals who exceed the rate. Therefore, people would watch their energy costs.

823 If they had to pay for utilities.

827 Make them pay for it themselves.

840 . Start charging excessive users.

842 Paying utilities.

857 Paying own utilities.

879 Charge a small fee every time someone is found guilty of not using energy wisely.

894 Start charging them utility bills monthly for anything that is used over an allowable quota.

910 A lot! Maybe a portion of an electric bill to pay on their own.

623 Thought of paying for what they use, or an incentive program.

358 To realize they could be paying for it in the future. Or have a set amount to be used monthly; if they go over that amount, they can be charged for it.

545 An example of what will happen if we keep using energy wastefully, and remind them often.

532 Threaten them with having to pay a portion of energy used by their household. Put a meter outside, or, if one already exists, then start showing them how much they do use. Hitting someone in the pocketbook always tends to wake someone up from their carelessness, whatever it may be!

249 The rumor that they may have to start paying for it \& people coming to inspect more often.

281 By stop telling those who move on post that soon they might have to pay for their utilities, they might care. I know myself, I figure if I'm going to be paying for it, I'll use it the way I want.

80 Tell them you will charge those who waste.

183 If they don't, then make them pay for it.

192 The possibility of having to pay for electricity and water.

200 Start a rumor that the Government is going to start making the military pay for the energy they use, just like those less fortunate not living on post.

209 Tell them they will have to pay the bill if they don't!

210 Just imagine having to pay for it yourself!

256 Threaten them to pay the bill!

278 Remind them if they had to pay for these services, would they continue the same pattern they have now.

312 Tell them if they don't then they'll have to pay like they did when they were living off post. 
329 I would let them know if they don't, someday they will be paying for heat and lights

331 If we are unable to use energy wisely - we will have to pay. That should motivate everyone! We try to use energy more efficiently - we teach our children to turn things on \& off and how we waste electricity by doing certain things and learn to use less energy.

336 Threaten to make them pay the electric bill.

355 Threaten to make them pay for excessive use.

382 Impress on them that one day they may be held responsible for the cost.

435 If you don't use it efficiently, they could make us pay the bills - I wouldn't want that.

466 Tell them they can pay it if they don't respect it.

468 Threat of paying for utilities.

476 Threaten to charge for excessive use of energy

487 Threaten with shared cost of a bill if over a certain amount is used (reasonable amount)

513 Warn them that excessive or unreasonable use will be charged to them.

519 Let them know if they don't start conserving, they will eventually pay for the waste.

602 Telling them that if they don't, they will start being charged for wasted energy.

659 Tell them they will have to start paying their utility bill.

704 Tell them they will soon be paying for utilities unless there is a change.

792 Tell them if they don't, we will have to pay for it ourselves.

796 Tell them if they don't save energy, Housing will start billing for the usage, like off-post tenants.

798 Threaten them that if they don't conserve, then they will have to start being billed monthly for utilities. It's harsh, but people will start to think.

841 Threaten them to start paying for water and electricity.

844 The thought of having to pay their own utilities.

862 The possibility of having to pay for energy.

864 Tell them they will pay for a certain amount if they do not try to save energy.

886 Tell them that they will have to start paying and they will do the right thing.

896 Threat of them having to pay for it.

905 Tell them they will be charged and you'll see. Since we are not paying rent, we can always get billed for electricity.

809 Promote the energy efficiency program more aggressively. Offer incentives for energy saving or, as a last resort, charge residents for excessive energy usage.

54 Present information at newcomer's briefing and offer incentives.

79 Consistent reminders, reward those who do conserve.

118 Put it out more about OEC and the prizes.

215 More publicity about program \& incentives. I really haven't heard much at all about the program.

347 Let them know more about incentive.

501 Possibly more reminders and/or incentives

530 Awareness - incentives

546 Give info and maybe put a percentage of savings back in community

607 Keeping information out to everyone. Incentives may. help other people who really don't care about saving energy..

610 Information and incentives.

776 Make suggestions to all residents and give each one copies. Give them motivation incentives, like giving discounts to the PX and other services inside the base. Names of people conserving the most in the newspaper circulated inside the base.

808 Public awareness; incentives. 
856 Don't patronize, tell them why its important to save energy and ask for their support. Be specific: Benefits who? What prizes? What's the goal? What has this campaign's progress been? What portion of government will benefit from these savings and how will these savings benefit soldiers and their families?

858 Reminders; prizes (like in this drawing).

908 Make a housing guide with ideas on how to save energy and give them some type of incentive to stay motivated to save energy.

128 Information, encouragement, enforcement

733 Keep reminding them. Some people on my street leave their sprinklers on all night. I think the MPs or somebody should watch them and stop them.

900 Continual reminders or having to pay own bills for energy use.

8 Getting out more information, and the threat of charging for it, when we barely make enough money as it is.

110 Polite reminders; cost savings illustrated on an annual or semi-annual basis.

315 More information. A monthly/quarterly account of what was spent/saved/given out to residents

385 Remind them of the costs

561 Being able to see the end result. I've never gotten this before, yet lived here more than a year

33 If there are ever any town meetings for each housing area, go and talk about it. Make it a more visible campaign. We moved in at the end of May \& had never heard of it until now. However, we do try to be sensible about using electricity anyway. Also, go to the schools and talk to the kids. A lot of times, they will try to enforce it at home. Mail out fliers with all of the energy saving tips and have housing give them out to every new family when they sign for the keys.

394 Send flyers about energy conservation or educate the residents about this issue.

657 Provide some tips on a newsletters. Have a mandatory class.

775 Someone coming out to each housing area and having mandatory energy efficiency monthly meetings.

136 More community and post-wide involvement, advertising, incentives, and awards

151 More education through motivation. Distributing information, communication. Mayors not in touch with the people!

428 Monthly reminder newsletter, unit involvement and less Housing intrusion.

18 Bring it up in meetings/ advertise in paper.

51 Keeping them informed and involved; together we can make a difference.

300 Reminders - and better, efficient homes

880 Something noticed in published report - The housing areas with new windows and doors had highest improvement respective to percentage of completed units and when done/started. These with old outdated exteriors (windows and doors) not even started yet had the worst $\$ 0$ improvernents.

700 If they know more about it. If certain things in housing didn't continuously break or take too long to get fixed.

712 Keep putting the word out. Also, when All Star comes in the fall to check the furnace, they should check to see if re-caulking needs to be done on the windows.

739 Information/repairs to leaky faucets.

745 To keep reminding them, or have an All Star maintenance person inspect all doors, windows, etc.

907 Meter readings given out at each unit would do it. Once again, we do all we can but housing is old and drafty.

500 Don't be condescending, energy conservation is common sense, send flyers of ways to conserve energy as reminders to people.

672 Awareness/I shut off lights/lower the heat because of the way I was raised (not to waste).

755 Just keep reminding them that it's the right thing to do. 


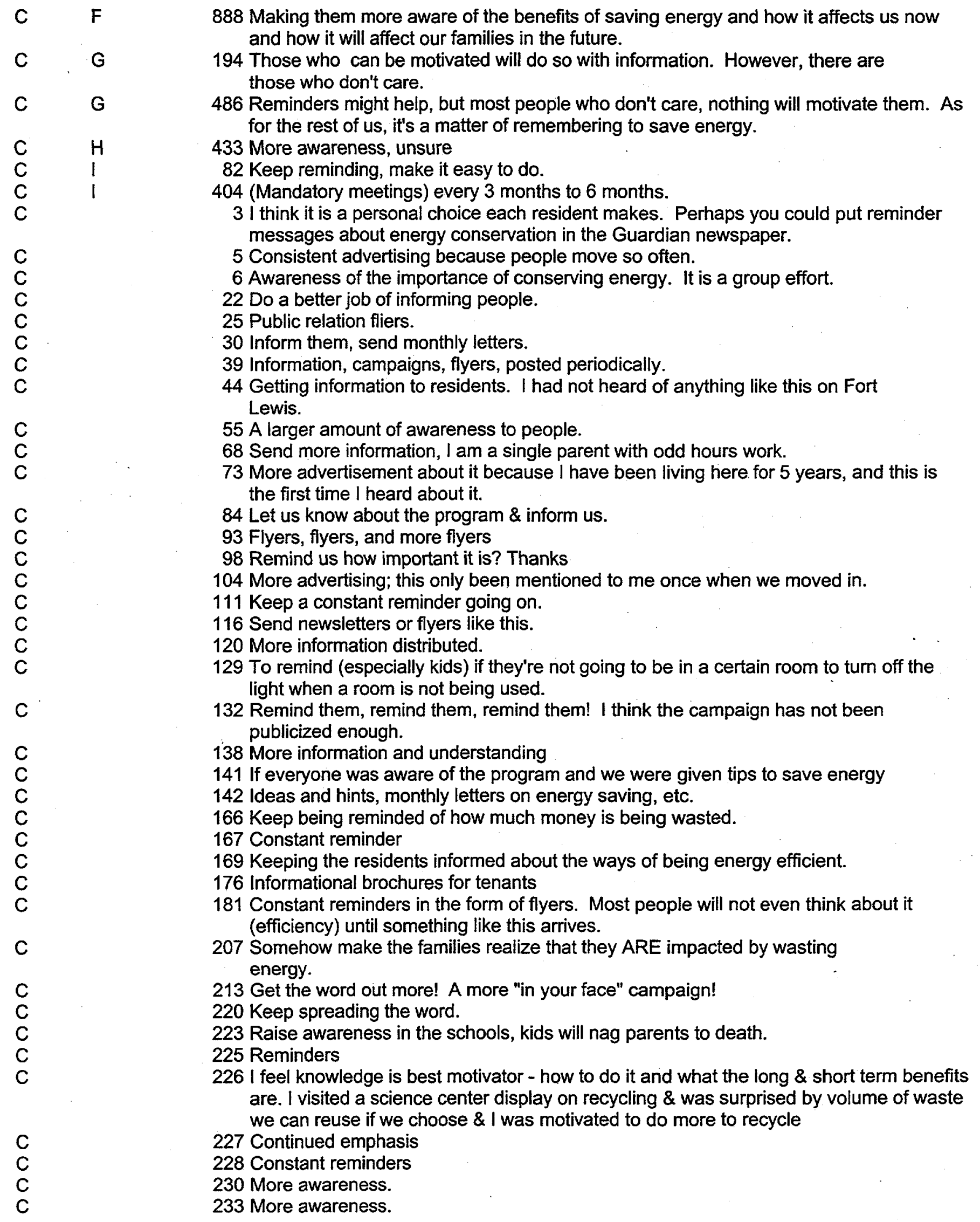


C

C

C

C

C

C

C

C

C

C

C

C

C

C

C

C

C

C

C

C

C

C

C

C

C

C

C

C

C

C

C

C

C

C

C

C

C

C
236 Friendly reminders from housing (posters, commercials on channel 3 , etc...)

237 Give out more fliers

243 Ask them to

251 More publicized information to remind people.

258 Make them more aware of the problems that wasting energy causes.

290 More information

299 More information

313 Communication

316 Keep talking about it.

318 Have more information residents.

324 Keep sending them messages to remind them to conserve energy all the time.

330 Make sure everyone knows the proper way to save energy. People sometimes we do not know certain things. Inform us with newsletters.

335 I feel residents would use energy more wisely if they understood how important it was maybe through pamphlets or seminars before you even move on housing.

339 Awareness of what can be done to conserve energy and the benefits that we all receive from saving energy.

345 Periodic flyers delivered to door.

350 More awareness, announcements, etc...

351 Keep them informed

365 Active awareness campaigns.

371 More publicity/awareness

381 Advertising and keep telling people to save energy

383 Have information distributed on how to save energy to residents, or pamphlets at Self-Help.

384 More information about how their little part is part of the whole.

387 Make them more aware, send out fliers if it was in community newsletter, make sure every one gets it because 1 do not.

389 Better awareness, add it to the briefing before you sign for quarters.

392 Remind them what days watering is issued etc...

397 Tell people about the program!!!

402 Hearing more about it would be good; this is the first l've heard.

409 Frequent reminders.

423 Inform us by mailings, information handed out during the meeting when we first get our house.

427 Ask them to and give suggestions on how.

431 Give out magnets or stickers to help get and keep people aware of the problem.

439 I just think it should be advertised more

446 Keep putting reminders around the housing areas, to ensure that it is wise to save energy.

450 Periodic reminders are enough for the people that really care about such things

455 You must have a conservation plan that everyone hears about.

Advertisements about it would help.

456 Keep all residents well informed about saving energy

459 To be informed, first of all. I didn't even know about it.

472 Inform all residents because I haven't heard of this program

477 Let us know more about it. Send out people to housing additions with fliers

479 Energy awareness mailers offering suggestions

497 Let new people know about it. I have lived here over a year and this is the first I have heard about it.

504 Constant reminders, I guess

506 Reminders

507 Persistence in reminding them 
509 Send out reminder notices on energy saving tips beginning in the fall through the winter and spring.

C

$\mathrm{C}$

C

C

C

C

C

C

C

C

C

C

C

C

C

C

C

C

C

C

C

C

C

C

C

C

C

C

C

C

C

C

C

C

C

C

C

C

C

$C$
$C$
$C$
$C$
$C$

524 Make the importance known to more people.

538 Send out reminders through newsletters

551 Post reminders on a monthly basis

553 Promote Operation Energy a bit more so people will be reminded.

555 Keep them aware of the importance of saving energy.

557 It has to be a constant reminder until people actually become used to doing what's best for the environment.

559 Flyers once per month as a reminder

560 Encouraging people more often to save some energy and use it wisely.

567 Make information more available

575 Keep putting it in the newsletter.

576 Keep them informed about different ways of saving energy.

578 Reinforcing the importance of saving energy.

580 Publish all ways of saving energy in community newsietters more often.

586 Make them aware of how they can save energy

612 Bring awareness.

615 Not many people know about this.

632 Communication. Newsletters from Mayors. Presentation of OSC meeting. Stress the wastefulness of leaving windows open and heat on. Sorry for delay, survey lost in a pile of mail. Please do not give up the effort. Also need stronger communication. Awareness of $\mathrm{H} 2 \mathrm{O}$ waste.

637 Providing more information on conserving energy. Telling maintenance workers to turn lights off when finished working on vacant houses.

639 Reminders, reminders, reminders.

640 A report every 3 months

674 Ask them to wash full loads of clothes and dishes only. Turn lights off when not in room or home. Take shorter showers.

685 Mail them flyers every month.

688 Move communication.

690 More promotion.

696 More information, and make sure it gets to each residence.

697 Keep reminding them of Operation Energy.

703 Please send us more useful information for saving energy.

710 More advertising.

714 More publicized information would be helpful.

724 Keep reminding them.

736 Make newcomers aware of campaigns like these.

740 Awareness

741 Friendly reminders keep conservation of energy in the front of my mind and the minds of my family members.

743 More information out to us.

756 Constant reminder!!! People don't like being told what to do, but consistency will take notice and action will be done.

764 For Housing to be more informative when they come up with energy efficient ideas.

765 Continue to advertise. Good reminder.

772 Just to keep on talking about it.

784 Produce a "reminder" such as a refrigerator magnet that residents can see easily to remind them of ways to save energy.

786 Put more information out.

788 More information and an influence for families to participate in saving energy.

790 Keep reminders out where they can be observed.

791 Just keep explaining why they should.

793 Place signs in the housing areas on who won the energy saving award. 
C

C

C

C

C

C

C

c

C

C

C

C

C

C

C

C

C

C

C

C

C. 1

A $C$

C.1 A $\quad$ D.1

C.1 A

C.1 B.1

C. $1 \quad$ B. 1

C. 1 B. 2

C. 1 B. 2

C.1 C

$\begin{array}{lll}\text { C. } 1 & \text { C. } 3 & \text { D. } 1\end{array}$

C.1 G

C. 1

C. 1

C. 1

C. 1
794 The program is great, but it should be more publicized. I did not know about it for 6 months, after I moved into housing.

800 Keep letting people know about it.

814 Receiving things like this in the mail will remind people, or at least make them think for a while.

819 Awareness campaigns.

824 Flyers suggesting ideas. A reminder in the mail every 2-4 months.

838 Constant reminders.

845 Communication.

849 Continue to educate and send out newsletters to remind to use energy more efficiently.

852 Awareness.

866 Continue with the information about the importance of saving energy and how we will be affected if we don't make a difference now.

869 More advice in flyers in the mail, more information about it.

871 Show on Channel 2 reasons why it is important to save energy.

873 More emphasis on energy awareness.

881 Awareness.

882 People need to be informed and told what the benefits are for them individually of conserving and using energy.

890 Maybe if they know more about the benefits of conserving energy.

892 Stress the importance of saving energy.

895 Energy conservation information on a regular basis.

903 Reminders

906 Lots of information.

911 Have more housing meetings to stress this issue.

912 Better information provided to occupants.

914 Give us ideas every month on a paper.

652 Community meetings to show now energy is wasted and how we can conserve. What the rewards are for the community who conserves the most, or other incentives. More advertising on conserving energy for Ft. Lewis.

53 Send them notices to let them know how much power they have used and trade it so that post housing can know when repairs are necessary. Offer incentives to people who keep their power usage low. Carpeting/replace windows on 2nd floor of town houses. The windows are currently single pane.

515 Show how much energy is being saved over the previous year's usage and what that $\$$ could possibly be used for (children's programs or something).

20 Send a bill to the residents to show how much we would be paying. If it goes above a certain allowance, make them pay.

314 Maybe show them the bill, or charge a fee for excessive use.

37 Show them how much their energy bill would be per month if they were paying it themselves. And perhaps tell them that they do not conserve energy, they may have to start paying their electric bill.

445 Show them what it would cost them for the energy that they use each month. Then threaten to charge them for what they use!

276 Maybe seeing what the bill for my home is every month. Knowing what is available at Self-Help to install etc., to keep energy efficient.

853 Show them a mock check of how much money they are saving the Army. Help mayors get a more involved neighborhood, give us housing that is better quality, not just the lowest bid.

510 For them to find out that we would have to pay for heat and lights. For some, nothing will help.

16 Benefits of Govt. housing: compare energy prices to non-Govt. housing.

52 Show them my electric bill from previous addresses.

94 Perhaps see what it costs to heat their house each month.

119 Show them now much they use monthly in a statement and what it would 

C. 1
C. 1
C. 1
C. 1
C. 1
C. 1
C. 1
C. 1
C. 1
C. 1
C. 1
C. 1
C. 1
C. 1
C. 1
C. 1
C. 1
C. 1
C. 1
C. 1
C. 1
125 Send out a statement (not a bill) of how much they would have to pay if they had to pay for it.
133 They need to see the results of the direct savings!!
144 Monthly charts on just how much is used - like you get with a normal electric bill
211 Knowing how much civilians pay for energy compared to us who live on post. There's a lot of waste in the housing areas.
291 Remind them how much it costs
325 Show them how much they use every month on energy!
352 Let them know what they could be paying, but aren't having to.
353 Send us info on what difference it makes and how we can benefit.
368 Send out fliers to people showing how much it would cost the average family if they had to pay water and electricity bills.
375 Send everybody a bill showing how much money they will pay if they live off post
390 Remind them what it would cost them when they live off post and have to pay for the utilities themselves.
401 Make residents aware of what they are actually using. Set up a comparison chart to help them understand.
471 Remind them how much it costs.
478 Help them to realize the mount spent on housing. Just because they don't pay it, doesn't mean they should not look at what it would usually cost.
488 To keep seeing the savings and to know what they are used for
495 Make them ware of how much each person uses and what it would cost them if they were not in the military. You will not always be in the military. Practice makes perfect.
517 Show them what their monthly utility bills would be for their individual quarters if they had to pay for it.
540 Send them a mock bill and let them see what it would cost to pay the electric bill every month.
565 Clearly visible signs of how each community is doing.
568 By showing how much residents waste every year in dollars. (a report of some kind)
604 Maybe by doing comparisons. Keeping post residents abreast of how much an average post resident uses compared to what a civilian residence with a comparable family size pays for utilities. I find off-post utilities prices outrageous and am grateful to have post housing.
C.1
C.1
C.1
C.1
C. 1
C. 1
C.1
C.1
C.1
C.1
C. 1
609 Make them aware of costs for electricity, water, gas etc. List the publishing usage in different neighborhoods and possibly billing units or single homes usage.
634 Sent itemized statements of what was used at each residence and how much over/under average the usage is.
660 Make them aware of their individual energy use and let them know if it's reasonable. In my 3 years here, I have never seen anything that would let me know.
677 Show some reports of what their housing saves them. (What they would have to pay if billed for your own utilities.)
680 If you would let them know how much energy they used and how much it would cost, if they have to pay for it.
699 Let them know how much they are spending.
711 Information on what our bill would have been - "ignorance is bliss".
742 Send them a bill stating what it would cost them if they had to pay the bill instead of the Army.
763 Individual house energy usage reports.
836 They should compare themselves on quarters and off post apartment. Off post is very expensive than on post.
863 Send residents a statement showing usage.

cost. 
C. 1

C. 1

C. 1

C. 1

C. 1

C. $2 \quad A$

C.2 A

C. 2 A

C. 2 A

C.2 A

C.2 A

C. 2 A

C. 2 B. 1

C. 2 B.1

C. 2 C

C. 2 C

C. 2 C

C. 2 C

C. 2 C. 1

C. 2 D.1

C.2 D.1

C. 2

C. 2

C. 2

C.2

C. 2

C. 2

C. 2

C. 2

C. 2

C. 2

C. 2

C. 2

C. 2

C. 2

C.2

C. 2

C.2

C. 2

C. 2

C. 2

C. 2

C. 2

C. 2
867 Make them aware of how much they're wasting because it's free, by comparing it to a house in a civilian community that has an average bill, and show how much they're now wasting and will have to pay upon leaving the service.

883 Show them the bill.

889 Make them aware of what they could be spending on the outside (civilian community).

891 Show them what it would cost if they paid the electric bill.

899 Report costs of electricity use (in post housing) and communicate benefit (in money) if we reduce by "X\%".... Won't that be thousands per year?

B.1 731 More education and incentives. Make each family pay.

C,3 302 Good education, continuous and some sort of incentives or maybe even a contest among the housing areas!?

95 Education and incentives.

186 Education and incentive.

407 Education and incentives, not penalties.

850 Education and incentives.

878 Mandatory classes, special awards or gifts.

184 Educate about cost. Have a "pay" month to let people know the cost of utilities.

188 Education; make them pay for its use.

537 Education and notification

541 Education/awareness

570 More education and more advertisement.

837 Education/information about the consequences of wasting energy.

288 Educate them on how to save energy \& how much it costs to provide us with heat, gas, electricity, etc. Some people might do better if they see what they would have to pay for it.

21 Educating people by having a rep. come to the house or community to talk to people about the energy campaign. I strongly believe you need to work at it. Propose to make housing more sufficient by building better housing areas. I have lived in housing for the past 19 years and yet not seen accurate housing being built at all. How disappointing.

218 Education; Army commitment to improve quarters.

552 Educate. Once I started, I felt guilty if I didn't continue

15 Education.

19 Teach habits; some people are not sure of what to do.

57 Keep educating us.

146 Give a class or handout every $3-6$ months to help remind us.

158 Just teaching them ways to save energy

160 More education

164 Training and awareness through education.

182 Educate people on the small things they do that waste energy.

204 Educate them regarding ways to save energy!

212 Teach them, tell them, but make it simple - or (most) won't do it.

235 For parents to teach their children and keep up with it.

241 Educate us, let us know what will make a difference.

244 Education

303 Educate, educate, educate.

310 Education

340 Educate

388 Educate the people that this privilege (of not paying) should not be abused

393 Education

405 Education

485 Education

539 Education about conservation

544 Education 
566 Education that it really does take money from them (smaller raises \%'s) because of waste.

569 More education

588 Education

626 Kids are very good reminders. Let them bring home information from school, and keep teaching them the effects of conservation.

725 Continue to educate them.

726 Mandatory energy classes prior to moving in.

754 Joint effort with the military and education.

773 Education, education, education - this is a great start.

815 Environmental education.

830 More education.

107 Have the community majors reiterate the importance of saving energy and the difference it will make for their family plus the incentive award.

150 Make sure mayors get the word out to their community, about the incentives, too.

298 Community wide meeting and money incentives.

180 Get the word out and get some mayors that care. We can do it. We just need some strong leaders and get the Army to fix some of the problems.

35 More surveys

179 A more active mayor, one that communicates with residents

491 There is a lot of water waste in our community. Sprinklers being left on all night and day. Housing needs to enforce their current watering rules. If the military wants to save $\$$, they don't need to hire a private agency to poll community members. They should have old fashioned community meetings to get people's ideas and to formulate results. Community members would feel involved.

514 Mayors should get more involved with all people - I don't even know who our community mayor is!

843 More surveys.

875 Have town meetings.

747 Renovate, incentives. Teach them how to properly water their own lawn.

328 Better housing, renovations, incentives. It helps to be proud of your home, not ashamed.

282 In our community the houses themselves need to be more energy efficient. Maybe give the resident who saves the most from month to month some type of "gift" or recognition.

430 Make older housing areas such as Parkway more energy efficient. Also have residents pay for part of the utilities, then they will be more aware of how much they use.

783 Our family used to live on the other side of Fort Lewis. We lived in Clarkdale for about three years. The first year we lived there we had single-pane windows. During the winter, we were constantly turning up the heat in our unit. Double-pane windows replaced the older single-pane windows the following spring. It was cooler in the summer, and we didn't have to turn the heat up so much in the winter. We now live in New Hillside, where we have single-pane windows. If I stand about three feet from the window, I can feel the cold draft coming in from outside. There are ceiling vents blowing warm air near the window. They make little difference. We find that everything else within our home is outstanding. We are happy living here and wouldn't think of moving just because the windows have their own vents. Thank you very much for reading this little note and we hope you have a good day. I know of a few people who leave their lights on 24 hours a day, 7 days a week. A couple of them believe because they

422 Upgrade quality of windows and publish what is being done in their community.

462 New windows in New Hillside and info sent out

$$
\text { C. } 43
$$




$\begin{array}{ll}\text { D.1 } & \text { C } \\ \text { D.1 } & \text { C } \\ \text { D.1 } & \text { D.3 } \\ \text { D.1 } & \text { D.4 } \\ & \\ & \\ \text { D.1 } & \text { D.4 } \\ \text { D.1 } & \text { D.4 } \\ & \\ \text { D.1 } & \text { D.4 } \\ & \\ \text { D.1 } & \text { F }\end{array}$

D. 1

D. 1

D.1

D.1

D. 1

D. 1

D.1

D. 1

D. 1

D. 1

D. 1

D. 1

D.1

D. 1

D. 1

D. 1

D. 1

D. 1

D. 1

D. 1

D.1

D. 1

D. 1

D. 1

D.1
751 Improvements to quarters (insulation, better windows, etc.) and a more proactive education campaign in energy conservation.

876 Better housing construction and infomercials.

489 Houses in better repair.

296 When they see that the military is just as interested in helping keep up the resident housing \& using correct material. Not cheap material \& making sure it's done right the first time \& by having energy efficient windows \& doors installed.

447 The Army to show an interest in improving the energy efficiency of its housing

795 If things are replaced when needed, such as windows, instead of being told to just put plastic on them, residents might feel that the Army cares about energy which in turn would make them more conscientious about the energy in our homes.

884 Quality of housing needs to improve. Overall Army attitude towards members, vs. Airforce or Navy.

676 I think to have us live in a house you respect, instead of old broken down homes. Allow more Self- Help projects, and basically allow people to be motivated and fix houses on their own.

58 Continue to upgrade government housing, especially the bathrooms.

61 Have windows and doors energy efficient. Windows don't fit; doors have large drafts coming in.

72 Support in installing energy saving measures like window seals, radiator gauges, etc.

90 Better windows and doors or glass screen doors to cut down drafty floors and rooms.

108 Weatherize apts.

152 Take care of the older housing, rather than the new!

185 Addition of efficient windows would help a lot for better natural light in house and to stop drafts.

271 New heating systems. The systems we have work against us!

273 Putting energy efficient windows in!

280 Probably a timer for light switches instead of regular light switch.

286 More renovations

295 I feel most people do. What would help people is to having the older homes renovated to become more energy efficient. The old homes in Greenwood are really bad in winter. You have to keep heat turned up just to keep the homes warm. You can feel cold air coming into the rooms through doors \& windows.

311 Upgrade windows and doors

321 When the housing is constructed better than it is.

326 Upgrade the quarters so it will be easier to conserve.

362 Come and update windows and remove the lead paint

386 Build more modern, energy efficient housing

406 It's not so much the residents here in Old Hillside. These buildings weren't designed for energy conservation. i.e.., carpet, insulated walls, single paned windows, and bad framework on doors.

414 Updating the subdivision with new windows, doors, etc...

419 Insulate the houses better. My house has to turn the heat way up to even feel warm.

421 Help make the houses more energy-efficient. When I run the heat, some rooms burn up, while others remain cold. I also think control should be kept about use of water. No one follows the schedule. Water is left on overnight, etc.

442 Better living quarters

444 Better housing than what we're currently in. They're full of asbestos.

452 Better insulation and windows. Put the vents in the floor instead of the ceiling - heat rises

463 Better housing. My windows are not sealed good enough; cold air flows there when they are shut, enough to make the curtains move. 
465 These houses need the new energy efficient windows and doors because the heat escapes in the cool weather and there is no ventilation in the hot weather. We also need siding

469 If we could have houses that weren't so energy insufficient then people would be more inclined to participate.

480 A lot of improvements to better insulate the walls and replace the old windows and doors in our quarters

484 Energy efficient windows that open to use the wind for cooling instead of box fans in summer and warm months. Carpet on the floors to insulate and keep warmer in winter.

498 In my opinion, the old stoves, refrigerators, and stoves should be replaced. They use less energy. The old dish washers run for a long amount of time, and don't clean well. I have washed by hand then put them in dish washer with bleach on rinse to sanitize them, and they came out dirty. I have an old Hot Point, and they don't clean well new, let alone when they are really old like mine. the lights in these housing areas blow very often, a new bulb may last about 2 weeks. There has to be some kind of short or leak to make them blow. The windows leak air, so you have to turn heat up higher. They are not well ventilated, so you use lots of fans in the summer, and in the winter you freeze when you take a bath, so you have to turn up heat, or use an electric heater. The water pressure outside is not very good. So when you water, you have to water longer, using more electricity, and the soil is so poor, the water runs right off, so you have to water more often, so grass and flowers don't die, because soil

505 Low cost should be enforced when living in housing with great doors, windows and built better than ours.

518 Newer buildings for all.

520 Better housing - more input

550 If this housing area was updated to include energy-efficient windows, and charge the air vents to forced air from floor rather than the ceiling, it would cost less to heat and would be easier to cool. The top in our living room is 95 in the afternoon due to the direct sunlight shining in. The "cooling" system does nothing to cool down the house, even with the shades drawn.

558 Do as much possible to improve the community housing. The prouder someone is about their living conditions, the more apt they will be to help out conserve energy, etc.

591 Provide energy efficient lighting to residents.

594 A house with warm floors in the winter and warm doors. The window change is good but I still feel air coming through my bathroom wall while I sit on the throne; it is a killer when you and your kids are sick and your feet are frozen from touching the floor for five minutes. Quality contracting instead of the cheapest bidder, and someone in the Army watching their work more closely, would have saved us tax payers a lot! I am one who spoke up, and there was nothing done about the complaints.

601 Upgrades to the housing.

638 We have old windows, singled-pane, and they don't shut tight.

643 Get better windows in our houses.

648 Cooperation with Housing and to have the work done. Catch phrase: "It's historical housing." That's why "it can't be done".

662 Redo housing area so it is not so breezy throughout the house. Make sure you give everyone miniblinds to block out all the cold air.

663 Update windows and siding.

665 The housing areas must be improved to be energy efficient. Insulation needs to be installed.

666 More energy efficient housing.

684 If Housing would fix the windows and reinsulate the houses.

686 Upgrade the housing - better windows and doors.

701 To upgrade the housing in some areas. Despite the best efforts, it does not work when your windows or doors do not shut properly.

748 New windows! 
\begin{tabular}{l} 
D.1 \\
D.1 \\
D.1 \\
D.1 \\
D.1 \\
D.1 \\
D.1 \\
\hline D.1 \\
D.1 \\
D.1 \\
D.1 \\
D.1 \\
D.1 \\
D.1 \\
D.1
\end{tabular}

D.1

D.1

D.1

D.1

D.1

D.1

D. 2 B.1

D.2 B.1

D.2 D.4

D.2 D.4

D.2

D.2

D.2

D.2
750 Outside lights on the street will save us from having to have the light around the outside of the house on all night. Our street is very dark.

758 Renovation of government housing.

762 New housing.

799 A thermostat instead of radiators.

801 Better built/looking housing.

804 Give them better housing to live in.

810 Make our houses more weather tight (i.e., fix windows, etc.) so that we can keep our heaters turned down.

822 Make the houses energy efficient. Good start with new windows, siding, and doors.

826 Put in new windows.

828 Remodel the whole house and not just the outside.

829 Better housing.

833 Add new windows, insulation, and newer appliances.

834 Have good insulation and windows with no drafts.

897 Make sure the buildings are worth caring about. If the whole place is old and falling apart. Why bother with saving?

898 One way to save major drying money is to hang clothing outside. I do it all the time. In many housing areas we have lived in, it was very difficult to obtain a clothes line. It is a shame that in many housing areas the clothes line is being removed. Want to save money? Put up the clothes line.

901 Better housing.

902 Too cold, can't stand gas heat, -makes my hair static-y, no carpets, problems with plumbing.

904 Better insulation and windows. It's freezing in here during the winter.

913 I requested a storm door in October 98 . I still don't have one. The windows are so bad here the cold air blows in.

919 Weatherize your houses.

920 Insulation improvements - I think many feel like "why bother" when so much heat is lost through old windows anyway.

205 Raise base pay to realistically cover utilities and have residents pay their own utilities.

556 Pay residents a utility compensation, then bill them for utilities. This compensation would have to be variable based on number of occupants and housing area, since each set of quarters is different in terms of energy efficiency. This would create a significant incentive. By conserving energy the resident could pocket some of the utility compensation. I think this would greatly reduce the installation's energy use.

191 Unfortunately, the last thing a soldier is concerned with is whether his house is energy efficient. Our Army is in horrible shape, no money for training or good pay. When we treat our soldiers better, then they will care.

760 If we could get crime down in our area, we all could shut our porch lights off. Not much that we can do. People don't care anymore because the Army is taking benefits away from soldiers so soldiers and families don't care anymore. That's why the Army is so short of soldiers. Soldiers are just waiting for their clearing day. It's a fact. We all can work on saving energy; it's a great thing. But Housing needs to do their part as well. That's where it all needs to start first.

608 Increased pay that reflects the $\$$ we save the army.

670 When you live on the economy, BAH usually doesn't cover the rent, much less the utilities. So when you live on post finally, it's nice to be able to run your heat so you're not cold and take more than 5-minute showers. Pay more BAH, and when we move on post, it won't be such a big deal.

885 Why don't we suggest pay increases that will make soldiers care about their jobs and the scant benefits they receive such as housing. OK, why not pay them wages a family can live on and worry about saving energy later.

918 If we start being charged, I think we should get a portion of our BAQ back. 


\begin{tabular}{ll} 
D.3 & C \\
D.3 & D.1 \\
D.3 & D.4 \\
D.3 & D.4 \\
D.3 & \\
D.3 & \\
D.3 & \\
D.3 & \\
D.3 & \\
\hline
\end{tabular}

D.3

D.3

D.3

D.4

D.4

D.4

D.4

$\mathrm{E}$

E

$\begin{array}{lll}\text { E } & \text { B.1 } \\ \text { E } & \text { B.1 } \\ \text { E } & \text { B.1 } \\ \text { E } & \text { B.1 }\end{array}$

470 Fix what needs to be fixed, to make it practical, And more information on how we can help!

338 If repairs would be done on drafts from windows and around doors! Thermostat/heating is old and Maintenance gave me no help!

364 Prompt service from All Star. Also feeling like Housing cared about how we military families live.

503 Repair broken applianced, repair windows, siding, bathrooms. Make people who live in on-post housing feel less than they are residing in projects.

26 If All Star would come out when they are called and ask.

32 All Star to do better repairs.

36 Get All Star to fix things right. My furnace only works when it wants to. All Star says there is nothing wrong with it.

70 Better maintenance.

416 In my opinion you need to get All Star to fix things. We have made appointments. three times that they haven't kept. Because we both work and can't take any more time off, we won't have them fixed. Because of this, we run all the hot water in our house out of the pipes every other day in order to have cold water to do laundry. A big waste of $\$ \$ \$ \$$ !

713 When Housing shows a more rapid response to fix these energy problems in all areas at the same time, not one area at a time.

752 If the houses were maintained better, such as replacement windows, it would save a lot.

915 You asked for my opinion about energy conservation at $\mathrm{Ft}$. Lewis. Well, here it is. I called All Star to get them to put more caulking into my windows because they are rather drafty. They told me that caulking would not fix the problem because it is due to the cheap or poor quality windows and frames that were used in my quarters. I live in the Evergreen housing community which for the majority are 2 bedroom single family homes. The homes are rather nice; however, every window in the unit is drafty and are single-paned. I have been told that we have the highest gas and electrical bill for quarters on post. Which is understandable because of the poor windows and frames. 1 had the front screen door replaced about 2 years ago because it wasn't closing properly and All Star couldn't repair it. The storm/screen door that they installed does not properly seal to the door frame because it's cheap and make-do. Therefore, if there is a draft between the front door and that screen door, the heat is not being $\mathrm{tr}$ 124 If our house was allowed to be our "home." Sometimes regulations get in the way.

126 Take away so many rules - so we feel the house belongs to us. Example: yard watering schedule.

320 A little appreciation from Housing.

613 Do right by the soldiers and their families; morale.

682 Stop talking about making us pay for these quarters. Housing [should] do a better job than sitting in their office.

782 By the Army doing its part.

590 Monitor energy use within the community and offer incentives to energy efficient homes, complex, duplexes, and something.

62 Drive around see who has outdoor lights on in the day and ticket/ warn the occupants. If they have light on outside in day time, who knows what other ways they are wasting energy indoors.

67 Monitor consumption, charge for excesses.

216 Meters to track household usage - Charge folks using more than the community average.

342 Meter it and make them pay for excessive use.

708 The bottom line - meter each house and bill each family for that amount over the average usage for their family size and house type. I do not advocate billing on post families for their entire usage, unless housing utility pay is provided for average utility costs. 


$\begin{array}{lll}\text { E } & \text { C A } \\ \text { E } & \text { C.1 } \\ \text { E } & \\ \text { E } & \\ \text { E } & \\ \text { E } & \\ \text { E } & \\ \text { F } & \text { B.1 } \\ \text { F } & \text { C } \\ \text { F } & \text { C } \\ \text { F } & \text { C. } 2 & \\ & & \\ & & \\ \text { F } & \text { C.3 } \\ F & \text { D.1 } \\ F & \text { G } & \text { H }\end{array}$

F

F

$F$

F

F

F

F

F

$F$

F

$F$

F

F

F

F

F

618 Keep a close eye on meters to see where the abuse is. Continue to remind people to conserve energy, and continue rewarding housing areas with improvements.

85 Installing meters at each residence as a means to advise each family how much energy they are using.

4 Monitor the neighbor better ( people watering at wrong times/days children etc.)

203 Close monitoring to those who waste energy, leaving outside lights on during daytime, etc.

357 Put meters on family quarters.

523 Monitor housing areas for sprinklers left on overnight and lights (outside) on during daylight hours.

531 Better review of water use of residents by housing staff.

669 People have to care about the earth and most could care less. Make them pay.

266 Encourage residents to be energy wise to make life easier for everyone. No one can live comfortably without energy in this fast-paced technological world we live in today.

702 Making them aware of the environment and educating or informing them of our precious resources.

877 They will either do it because it is the right thing to do, as we have always done, or they won't care what motivation is provided. The education is good though, it reminds residents to be energy aware and offers ideas that residents may not have given any thought.

162 See how we can help make a difference individually in our neighborhood.

811 Self discipline is all it takes, but newer houses would be nice.

464 I don't know. I believe you should use energy wisely to conserve it. I feel it is important to be energy conserving. I believe that what they do now is a good idea as far as repairs on housing areas with money they save on energy. ex., siding, painting, sheds, etc...

257 Remind residents that as tax payers, we all pay for the energy used in our homes. Energy conservation has been a priority of the energy saving exercises listed and always have. This campaign changes little for us. Good luck!

757 Unsure. Learning this skill of saving energy comes from the way you grew up. We had to put 25 cents in a cup if we left on lights. Some people just don't care, even if they are paying for it.

417 it should come natural to them.

41 Start a program to let them know it not free, people; you pay for it. And we also need to conserve energy and not deplete the old supply.

65 One's own will to help the environment.

69 I believe that saving energy is primarily self-motivated. It is very unfortunate that I have seen unconcerned people violating energy-conservation tactics.

103 People thinking about how much money they lose as a whole not conserving energy.

156 It shouldn't take anything. It's the best way to preserve our future resources.

197 Saving energy helps our future generations!

214 Their state of mind \& how important it is to them.

247 Have them lose the attitude that they don't have to pay so they don't care!

395 Pretend it's your house that you're paying for - don't take housing for granted.

408 Remind them it's not just energy they are saving; it's the world for their kids that's at stake.

554 It is a moral decision, and the residents who do not feel responsible won't be. But the happier the residents are with housing, the more willing they will be to conserve energy and save money for the Ft.Lewis community, ensuring a higher standard for on-post living.

582 Common sense!

584 Realizing if the military has to spend money on people who do not us their energy wisely, then there will be less money to spend on other things like new military

$$
\text { C. } 48
$$


housing.

606 Maturity. The desire to help the environment.

620 You should remind them that even though they are not paying for it, the government (or someone) is. It is wrong to take advantage of living on post because it's a privilege, it's not something they have to do. Plus, if more people take part, that energy saved may be used for more important purposes or help in some other way.

630 Our efforts contribute to the environment

636 We all win when we become wise consumers.

646 Encourage responsibility for the environment.

651 Teamwork. Always save our energy; will be much easier for us to be survived into the bright world. If it wasn't for lights/energy, we couldn't be seeing the bright. So Hello, I suggest to please turn off those lights when daytime just to save our community more power/energy. Thank you.

664 Some common sense and determination to save the environment.

692 I don't know. Hopefully just plain common sense.

730 They should anyway, for the kids' sake.

738 Remind them that we are all paying the bill in one way or the other.

802 Remind people of individual responsibilities.

818 Treat like your own house.

820 A commitment of pride and determination - just do it, conserve energy.

851 Common sense approach to this issue as they should know it really is necessary.

865 That reminder when you purchase your own home, then you will conserve energy wisely.

870 Protect the earth.

872 Save for your kids.

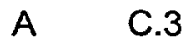

B.1

C

C.3

369 Campaigns like this, or housing area get-togethers for the winners. We need more community/neighborhood events.

366 Nothing, these people don't care! Maybe if they were fined for excessive water, leaving hoses running, etc...

687 Not sure. Think this program is a good reminder. Perhaps periodic energy saving tips would help.

323 Nothing different than what you are doing - pass word through units!

173 I think most people (residents) do try their best to do their part. Highly recommend authorization in Old Hillside for a clothesline outside.

31 I feel that I do pay for it. So we try to use energy wisely.

49 As long as there are immature people living in housing, nothing can motivate them because most of them think it is not a priority for them.

76 Most people know and try to be energy efficient.

140 You are doing everything you can right now!

178 I like what's going on already. But our neighborhood is the biggest money saver already.

201 I feel most don't seem to care because they don't pay utility/maintenance bills.

217 We already do all of the energy saving measures listed above.

284 Letter like this one

332 I don't think you can - people will do what they please no matter the consequences.

399 I think the longer they don't pay for it, they won't listen about other peoples' preoccupations

426 Exactly what you are doing now with the drawings.

475 Don't think anything would motivate residents. Only the ones who really care will make a change.

483 More than aware how important it is. 
490 I don't foresee anything waking people up to what is (obviously) a worldwide energy crisis. Change starts with one person, but unless others recognize the need for change - that one person will make very little difference and will come too late.

511 Nothing. My neighbors just don't care; they said they don't pay the bills, so they don't care

536 I think the majority already do.

548 Program like this.

562 The fact that the question states "keep" and not "start" tells me they are doing ok and don't need any more motivation.

589 Yeah right -- most people can't even drive the speed limit.

617 The same program.

635 I think if they do not care, nothing will make them care.

655 More campaigns.

658 Nothing will, if they don't want to.

675 I do not think that many people in the Army or any other military service really care about it and they probably not change.

721 Most people I live around do pretty good.

759 I think that you are on the right road now.

806 Because residents don't pay for their energy, most residents don't care what they use.

367 Not sure, I don't think they care because it is base housing but I think you should turn off lights etc., when not in use. I've always done energy saving things, but that's just me.

734 I don't know, I have never wasted energy.

56 I am not sure. I do think that we should not get awards; we should just know to use it. Plus, when we are move out and start paying for it ourselves, we will pay for it later, because we will all be in the habit of the government paying for it.

\section{4 ?}

24 I am not sure that there is an answer for this question.

38 Not sure.

48 I do not know.

77 I do not know.

115 I do not know.

163 Nothing I can think of.

170 Can't think of anything because utilities are already paid.

193 I don't know.

199 Have no ideas right now. Just got back from Korea.

246 Don't know

274 Unknown

279 I don't know

294 I'm really not sure because everyone has different motivators

349 Do not know

424 I am not sure.

440 Unknown

461 No idea

474 Not sure

493 Don't know

572 I really do not know.

595 Not sure.

597 I don't really know.

647 I really do not know

744 I don't know, but I would like to see more people recycling as well.

787 I'm not sure.

$825 \mathrm{I} ' \mathrm{~m}$ not sure.

847 Don't know.

855 No opinion - thanks. 
922 I'm not sure. Have no answer.

83 Fresh innovative ideas and incentives.

B D 265 Clothesline, limit amount able to use

40 To make this when resident signs for housing.

47 One day especially meant to save energy, just like use of water.

75 Ask residents this question: When your children are grown and on their own, what do you think they will be paying for gas/electricity?

96 We do not want to pay electricity.

109 To help upkeep better appearance, both inside and outside the home.

112 Use energy properly, not when it's not necessary.

154 Plenty of ideas - not enough room to write them

177 When one pays for something, one is more careful.

267 Continue to make energy conservation a priority.

283 More people becoming energy conscious

285 Not having to pay for it ourselves

297 I don't really know people who are energy wasters.

307 N/A

334 Continue getting free utilities.

361 Continuous participation; don't start off on on fire and then blow it off.

363 I would like to see recycling offered, and that would kick off thoughts toward all consumption.

374 You have to care. If you don't, they won't be motivated, no matter what!

412 I think it is a waste of tax payer money sending out these surveys.

441 Setting the thermostat to conserve energy.

457 Keeping the lights off, when not using. People think just because they're not paying for it, that no one is.

492 I have only lived here for 3 months but I haven't noticed anyone abusing electricity, can't say the same about water.

496 Making it easier and cheaper to clear (move outof) housing

581 Personal contact with residents... Tools to teach kids!

585 Competition between housing communities to save the most

593 Make it easy for busy families to fit into their schedules. Most people will do things if it is easy and convenient.

596 People will remember and be regardful and be dismayed

616 A community campaign.

624 Working together as a unit:

644 Put out more notices. There weren't any here at all.

715 Lazy spouse. Get out of the house more -- if you're not home, you save energy.

768 Think.

868 If we weren't made to feel it was a must.

921 I don't know - but it would help if our neighbors didn't have their bathroom lights and fans on all night. Not only does it waste energy, it is noisy. 